\title{
When and how does law effectively reduce the practice of female genital mutilation/cutting?
}

Josephine Wouango

Susan L. Ostermann

Daniel Mwanga

Population Council

Follow this and additional works at: https://knowledgecommons.popcouncil.org/departments_sbsr-rh

Part of the Demography, Population, and Ecology Commons, Family, Life Course, and Society Commons, International Public Health Commons, and the Sociology of Culture Commons How does access to this work benefit you? Let us know!

\section{Recommended Citation}

Wouango, Josephine, Susan L. Ostermann, and Daniel Mwanga. 2020. "When and how does law effectively reduce the practice of female genital mutilation/cutting?" Evidence to End FGM/C: Research to Help Girls and Women Thrive. New York: Population Council. 


\section{Evidence to End FGM/C}

Research to Help Girls and Women Thrive

\section{WHEN AND HOW DOES LAW EFFECTIVELY REDUCE THE PRACTICE OF FEMALE GENITAL MUTILATION/CUTTING?}

April 2020 


\section{WHEN AND HOW DOES LAW EFFECTIVELY REDUCE THE PRACTICE OF FEMALE GENITAL MUTILATION/CUTTING? JOSEPHINE WOUANGO UNIVERSITY OF LIĖGE, BELGIUM \\ SUSAN L. OSTERMANN UNIVERSITY NOTRE DAME, USA \\ DANIEL MWANGA POPULATION COUNCIL, KENYA}


The Evidence to End FGM/C: Research to Help Girls and Women Thrive generates evidence to inform and influence investments, policies, and programmes for ending female genital mutilation/cutting in different contexts. Evidence to End FGM/C is led by the Population Council, Nairobi in partnership with the Africa Coordinating Centre for the Abandonment of Female Genital Mutilation/Cutting (ACCAF), Kenya; the Global Research and Advocacy Group (GRAG), Senegal; Population Council, Nigeria; Population Council, Egypt; Population Council, Ethiopia; MannionDaniels, Ltd. (MD); Population Reference Bureau (PRB); University of California, San Diego (Dr. Gerry Mackie); and University of Washington, Seattle (Prof. Bettina Shell-Duncan).

POPULATION COUNCIL

Ideas. Evidence. Impact.
The Population Council confronts critical health and development issues-from stopping the spread of HIV to improving reproductive health and ensuring that young people lead full and productive lives. Through biomedical, social science, and public health research in 50 countries, we work with our partners to deliver solutions that lead to more effective policies, programmes, and technologies that improve lives around the world. Established in 1952 and headquartered in New York, the Council is a nongovernmental, nonprofit organisation governed by an international board of trustees. www.popcouncil.org

Suggested Citation: Wouango, J., Ostermann, S. and Mwanga D. 2020, When and How Does Law Effectively Reduce the Practice of Female Genital Mutilation/Cutting? Evidence to End FGM/C: Research to Help Girls and Women Thrive. New York: Population Council.

This is a working paper and represents research in progress. This paper represents the opinions of the authors and is the product of professional research. This paper has not been peer reviewed, and this version may be updated with additional analyses in subsequent publications. Contact: josephine.wouango@uliege.be.

Please address any inquiries about the Evidence to End FGM/C programme consortium to:

Dr Jacinta Muteshi, Project Director, jmuteshi@popcouncil.org

Funded by:

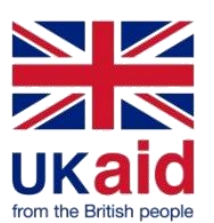

This document is output from a programme funded by UK Aid from the UK government for the benefit of developing countries. However, the views expressed and information contained in it are not necessarily those of, or endorsed by the UK government, which can accept no responsibility for such views or information or for any reliance placed on them. 


\section{Table of Contents}

List of Acronyms

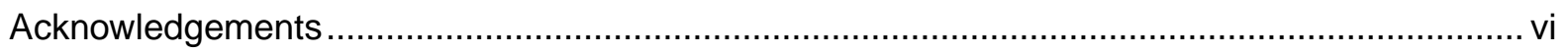

Executive Summary .............................................................................................. vii

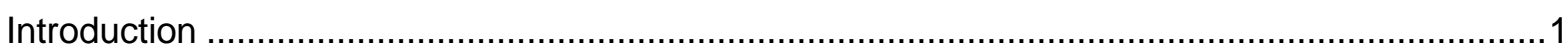

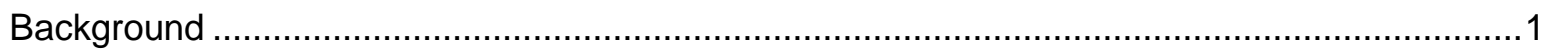

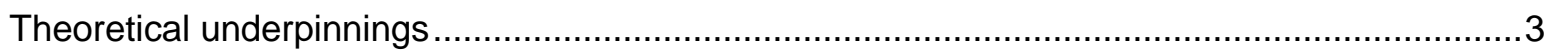

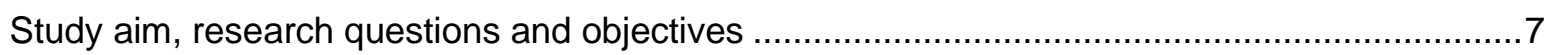

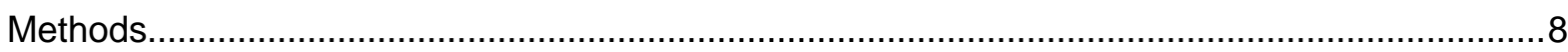

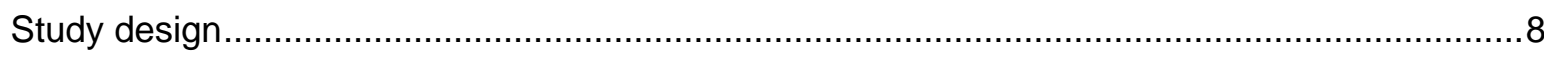

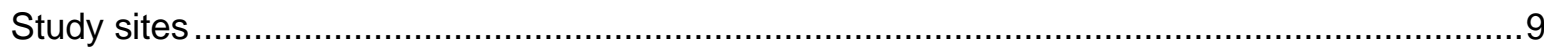

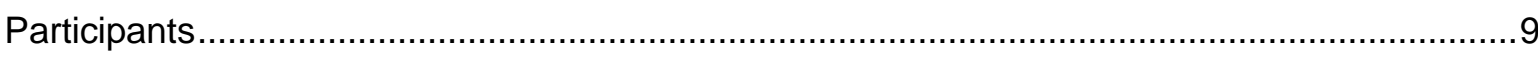

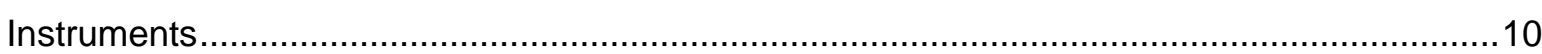

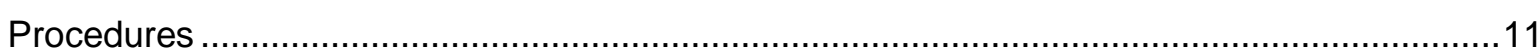

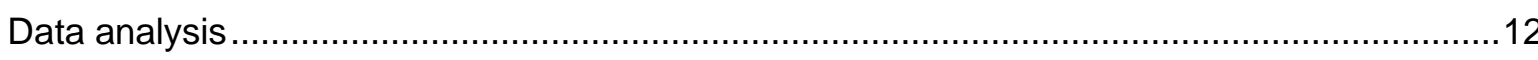

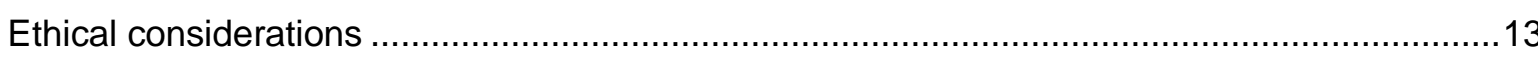

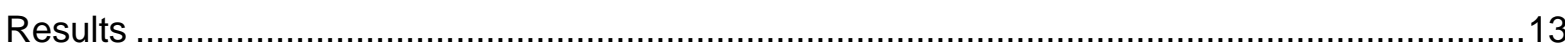

Socioeconomic and demographic characteristics of participants ...........................................14

Types of Disputes and Conflict Resolution Mechanisms......................................................16

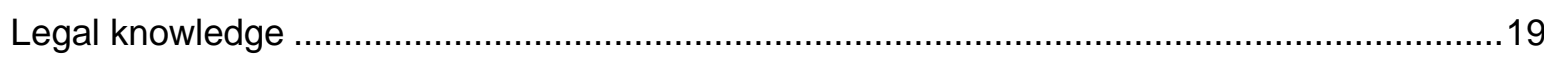

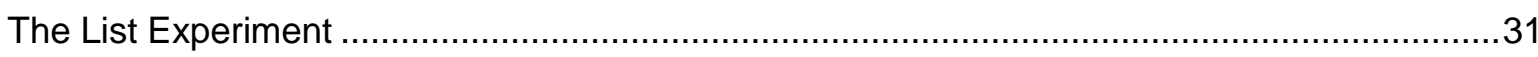

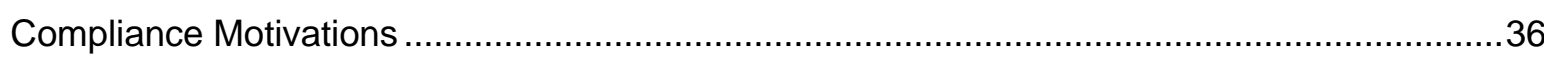

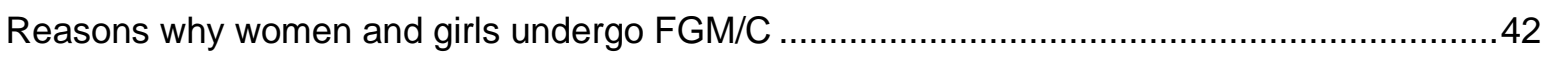

Reasons for women and girls not undergoing FGM/C ..................................................52

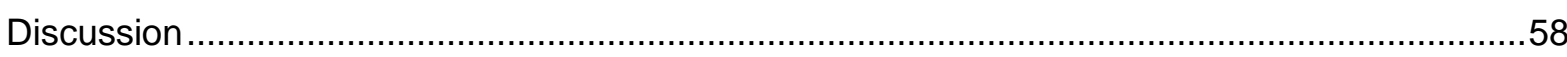

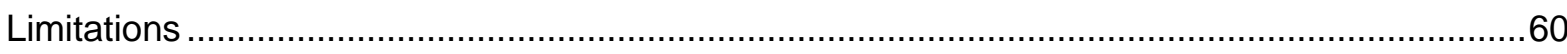

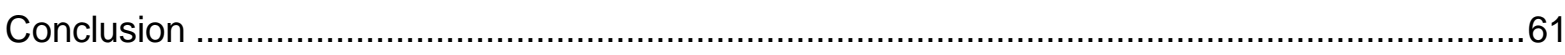

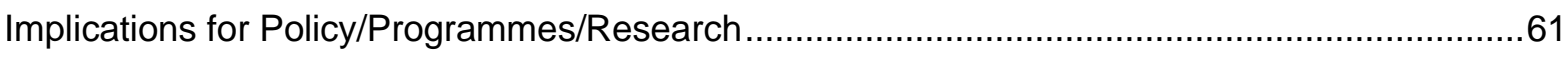

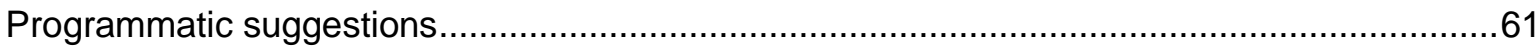

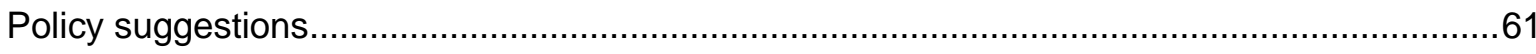

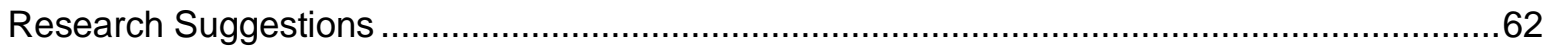

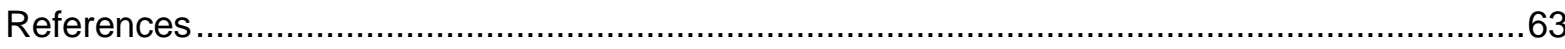

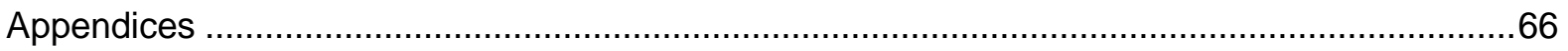




\section{List of Acronyms}

$\begin{array}{ll}\text { BF } & \text { Burkina Faso } \\ \text { CNLPE } & \begin{array}{l}\text { Comité National de Lutte contre la Pratique de l'Excision (National } \\ \text { Committee to Fight Against the Practice of Excision) }\end{array} \\ \text { COFO } & \text { Commission Foncière (Land Commission) } \\ \text { CVD } & \text { Comité Villageois de Développement (Village Development Committee) } \\ \text { DFID } & \text { Department for International Development } \\ \text { DHS } & \text { Demographic and Health Survey } \\ \text { FGD } & \text { Focus Group Discussion } \\ \text { FGM/C } & \text { Female Genital Mutilation/Cutting } \\ \text { NISD } & \text { National Institute of Statistics and Demography } \\ \text { KIIS } & \text { Key Informant Interviews } \\ \text { IRB } & \text { Institutional Review Board } \\ \text { MICS } & \text { Multiple Indicator Cluster Survey } \\ \text { NGO } & \text { Non-Governmental Organisation } \\ \text { PI } & \text { Principal Investigator } \\ \text { UNFPA } & \text { United Nations Population Fund } \\ \text { UNICEF } & \text { United Nations Children's Fund } \\ \text { RA } & \text { Research Assistant } \\ \text { WHO } & \text { World Health Organization }\end{array}$




\section{Acknowledgements}

This report is a part of a research programme supported by UK Aid and the UK government through the Department for International Development (DFID)-funded project "Evidence to End FGM/C: Research to Help Girls and Women Thrive" and coordinated by the Population Council. Our 30 research asssitants (RAs) and team leaders from Burkina Faso were vital to the success of this study. They collected data in the risky environment in Mali and Burkina Faso where terrorist attacks were happening regularly. They took enormous risks to bring us the data. We acknowledge their invaluable courage and contributions. We thank the government representatives, local and religious leaders, security forces in the six villages in Mali and Burkina Faso, and authorities at the regional level in both countries who facilitated the work of our team on the ground and protected our RAs throughout the data collection. A particular thank you to Dr. Kadari Taoré, our facilitator in Mali who supported Principal Investigator (PI) Wouango throughout the Mali Institutional Review Board (IRB) approval process, introduced the leading team to authorities in Mali, and facilitated the work of our RAs during the data collection. Implementation of the study in Mali would have been impossible without his exceptional contribution and dedication. In Burkina Faso, we received invaluable support from the National Committee to Fight Against the Practice of Excision (CNLPE) who connected us to authorities in the capital Ouagadougou, and introduced us to regional and local authorities, security forces, and local leaders in the study sites in Burkina Faso. They have been key to the success of our data collection in Burkina Faso. Finally, thank you to the Burkina Faso management team, Dr. Lougue Siaka, the research study manager, and Mr. Zakaria Ouedraogo, the programmer. All these great people contributed to the success of this complex study carried out in a volatile security environment.

We are grateful to the expert reviewers whose input and critiques have improved the quality of the final report: Professor Patricia Mbote, School of Law, University of Nairobi; Julienne Weiss, USAID; Brian D. Earp, Yale University \& University of Oxford; and, Micheline Hindin, Population Council. 


\section{Executive Summary}

\section{Background}

Female genital mutilation/cutting (FGM/C) is recognised globally to carry risks to both the physical and psychological health of girls and women and is widely considered to be a violation of human rights. An estimated 200 million girls and women in 30 countries have undergone $\mathrm{FGM} / \mathrm{C}$ and as many as 30 million girls younger than 15 years of age are at risk (UNICEF 2016). A common policy response to $\mathrm{FGM} / \mathrm{C}$ is to call for the enactment and enforcement of criminal prohibitions on the practice. Yet, the law and society literature (Tyler 1990; Friedman 2016) suggests that compliance with laws is complex: it can be motivated and undercut by moral, social, religious, and incentive-based factors. We chose to conduct this study in two neighbouring countries, Burkina Faso (which has a strong FGM/C law) and Mali (which has no specific FGM/C law), so as to explore attitudes and tendencies towards obeying the law and continuing FGM/C practices while controlling for many potentially confounding variables.

\section{Methods}

This study uses a mixed-method design that was implemented on the basis of a borderdiscontinuity. Data were collected in six pair villages along the Burkina Faso (BF)-Mali border and each pair village was chosen to reflect the same majority ethnic group (the Bobo in Faramana-BF/Koury-Mali; the Senoufo in Koloko-BF/Finkolo-Mali, and the Bwaba in TansilaBF/Boura-Mali). Our target population was men and women aged 18 years or older. In the quantitative study, we sampled randomly, using the right-hand rule and Kish method. The qualitative component was composed of Key Informants Interviews (KIls) and Focus Group Discussions (FGDs). Key informants were purposively selected from various positions within the chosen communities in order to understand participants' opinions about the moral, social, and legal rules in the community. The FGDs involved eliciting indirect responses to prompts on statutory law using FGM/C vignettes.

\section{Results}

Knowledge of legality of FGM/C: The vast majority of respondents think that FGM/C is illegal ( $87 \%$ of all respondents in Burkina Faso and $80 \%$ in Mali). The results in Burkina Faso were consistent with previous studies, but the Mali results were surprising in that Mali does not have a specific law that criminalises and punishes the practice of FGM/C. Radio was the main source of information about the law in both countries, as well as for all quantitative and qualitative participants, and the Mali quantitative results may be partly explained by cross-border diffusion of anti-FGM/C messages form Burkina Faso.

Compliance motivations: $54 \%$ of all respondents reported a motivation to obey statutory law in general that flows from a sense of legal obligation and from believing others to behave similarly (54.4\% in Burkina Faso and 53.6\% in Mali). When respondents were asked what they thought motivated others to obey customary law in general, fear of social sanctions (ancestors, gods, etc.) was reported by $33 \%$ of respondents, while respect for the law was mentioned by $27 \%$, and this is approximately equivalent to what motivated the respondents individually to obey customary law. There is no single, accepted definition of customary law. The definition by Stavenhagen and Iturralde (1990, p. 29) reflects the context of our study: "customary law is generally understood to mean a set of unwritten, uncodified traditional legal norms and practises which are distinct from the positive law in force in any given country." 
Legal disobedience: When there is a conflict between statutory law and religion/customs, only $28 \%$ of respondents in both countries said it would be permissible to disobey the statutory law if it contradicts with their religion/customs, while $60 \%$ of respondents said they would disobey customary law if it contradicts with their religion. Respondents in both countries said it is permissible to disobey statutory law if it is clearly against one's moral principles $(65 \%)$, if one knows the law is not enforced $(61 \%)$, if one does not know about the law $(71 \%)$ and if one thinks the law is enforced unfairly $(69.9 \%)$.

Reasons for continued FGM/C practice: Many quantitative respondents believe that $\mathrm{FGM} / \mathrm{C}$, (the WHO type I and type II being mostly practiced) is permitted by their religion (15.8\% in BF and $18.3 \%$ in Mali) and customs $(20.7 \%$ in BF and $22.5 \%$ in Mali). The qualitative results generally confirmed the quantitative data in this regard, linking the continuation of $\mathrm{FGM} / \mathrm{C}$ practice to customs and religion, as well as to a stronger emphasis on religion in Mali, as compared to Burkina Faso. Depending on the country, the ethnic groups and the experiences of the participants, a variety of reasons were invoked to justify the continuation of the practice: culture/tradition, social reasons (such as marriageability), health reasons, pressure from elders, and the regulation of women's sexual desire.

Continuation/discontinuation of FGM/C: In our quantitative survey, $17 \%$ of respondents stated that they would practise FGM/C even if everyone else in their community stopped (14\% Burkina Faso, $21 \%$ Mali) and $18 \%$ of stated that the practice should continue (15\% Burkina Faso, $21 \%$ Mali). The majority of respondents, however, were supportive of FGM/C abandonment, as long as everyone does it (83\% in Burkina Faso and $77 \%$ in Mali). This same topic was covered with qualitative participants (KII and FGD) via vignette and results confirm support for abandonment despite resistance from some families and the persistence of underground cutting. Qualitative respondents indicated that abandonment is motivated by the health consequences of cutting. Continuation is motivated by a fear of social isolation or marginalisation.

\section{Discussion}

This study reveals important findings in terms of knowledge of FGM/C law, as well as motivations to obey and defy the law in general and FGM/C law in particular. There is a widespread belief that FGM/C is illegal in both countries, despite the fact that Mali does not have a law that specifically crimnalises the practice of FGM/C. Progressive attitudes and behaviours in line with the international agenda, motivated by health consequences and other reasons, also support a shift towards FGM/C abandonment. Being an uncut girl does not seem to be taboo everywhere in surveyed communities. The medical narratives of the health consequences seem to be working, as well as the impact health workers have had on convincing some parents to abandon the practice or at least to say that they would do so. The innovative list experiment shows that the 20 years of efforts made by Burkina Faso's government have produced results in the three villages included in the study, as the projected future prevalence rates for all villages in Burkina Faso are far lower than those of their counterparts in Mali. That said, some families continue to defy anti$\mathrm{FGM} / \mathrm{C}$ laws and all related interventions undertaken to date.

\section{Implications for policy, programmes and/or research}

\section{Policy implications}

Governments and nongovernmental actors looking to end the practice of FGM/C should (1) continue to support sensitization and awareness-raising campaigns implemented by the government of Burkina Faso over the last 20 years; expand such campaigns to include people still defending the practice; try to persuade local leaders within practising communities to join the abandonment movement already happening in study communities; and highlight the lack of negative social consequences for girls/families who decided not to cut. They should also (2) 
strengthen the role of health workers as key influencers and agents of change in all interventions aiming to eliminate FGM/C in Burkina Faso, Mali, and beyond. Finally, they should (3) implement and strengthen international coordination/cooperation to eliminate cross-border FGM/C through a regional law targeting cross-border and in-country FGM/C and community-level implementation.

\section{Research implications}

Future research should (1) investigate factors that have led people in the study areas in Mali to think that FGM/C is illegal when there is no FGM/C law in Mali. It should also (2) scale up crossborder research to include other countries neighbouring Burkina Faso that have an FGM/C law (Côte d'Ivoire, Ghana, Niger) and where Burkinabe families also cross the border to have their daughters undergo the practice (GRIGED 2008; UNFPA 2016); replicate the list experiment to assess the effect of law (or its contribution) on FGM/C abandonment in order to strengthen the findings. Finally, future research should include a sound anthropological study, with immersion of researchers in individual communities, to provide an in-depth understanding of how to tackle those who strongly resist anti-FGM/C policies and interventions. 


\section{Introduction}

\section{Background}

Female genital mutilation/cutting (FGM/C) refers to all forms of medically unnecessary cutting of the female genitalia. It comprises all procedures that involve partial or total removal of the external female genitalia, or other injury to the female genital organs for nonmedical reasons (WHO/UNICEF/UNFPA 1997). The "cut, flesh removed" is the most common type of FGM/C practised both in Burkina Faso and Mali (28TooMany 2018). FGM/C is recognised globally to carry risks to both the physical and psychological health of girls and women and is widely considered to be a violation of human rights.

\section{Burkina Faso}

Burkina Faso is a landlocked country of over 18 million people, lying immediately to the southeast of Mali. Both countries are part of the same West African macro-culture, sharing some of the same ethnic groups. FGM/C prevalence has been historically high (87\% among those aged 45-49 years as of 2015) but has been declining since 1985 (UNFPA 2018). In 2015, it was estimated that $\mathrm{FGM} / \mathrm{C}$ prevalence was $42 \%$ in 2015, among those aged 15-19 years (UNFPA 2018). FGM/C prevalence in Burkina Faso has traditionally been measured through Demographic and Health Surveys (DHS) data, particularly the DHS surveys of 1997/1998, 2003 and 2010. The methodology used in these surveys relies on self-reporting from women or the parents of younger girls. Though the latest Demographic and Heath Survey (DHS) IV 2010 and the multisectoral ongoing survey (Enquête Multisectorielle Continue-EMC) 2015 provide data on girls aged 0-14, the others focused more on women aged 15-49 (INSD 2012, 2015). According to a new study of the legal frameworks associated with FGM/C in West and Central Africa, with special attention to Burkina Faso, the country was one of the first to criminalise the practice and the government's implementation is "exemplary and unique" (UNFPA 2018). Since its passage in 1996, the law punishes cutters as well anyone who knows of the cutting and fails to report it to the authorities (CNLPE 2016a, 2016b). A recent study by Crisman et al. (2016, p. 33) explained that while there is evidence of a recent decline in the $\mathrm{FGM} / \mathrm{C}$ rate in Burkina Faso, enforcement of the law should be done in conjunction with other strategies:

"Our analysis demonstrates that in Burkina Faso, the passage of a law against FGM/C resulted in a decrease in the likelihood that the average woman or girl would be cut. We find that the impact of the legal change is varied across religious and ethnic subgroups as well as by administrative region. However, we stress again that legislation should not be understood to be operating in isolation, absent wider shifts in attitudes, social practises, and government and civil society efforts to alter each of them."

A US State Department Report (2009) says that recommendations to abolish FGM/C were discussed publicly in 1985, and many programmes of education and advocacy have been carried out since. In 1990, President Blaise Compaoré (President of Burkina Faso from 1987 to 2014) issued a decree imposing fines on those who were found to be performing FGM/C and decreed the formation of the CNLPE, actively supported by the First Lady, Chantal Compaore, who was its honorary chair. Since its formation, the National Committee has organised a wide variety of activities and programmes. Among them, starting in 1990, and unique in the world, an SOS Excision Hotline (Diop et al. 2008). Anyone can call the hotline, which is set up within the SP/CNLPE and allows the population to call free of charge and anonymously to report any case of practice of $\mathrm{FGM} / \mathrm{C}$ or intention to practise. The hotline is managed by security forces placed at the disposal of the SP/CNLPE. In the event of a denunciation, the appropriate services (police, gendarmerie, social action, etc.) located in the village/city of the denunciation is contacted to intervene to stop the intention to cut or, when the cutting is already performed, to arrest the cutter 
and any accomplices (CNLPE 2016). Hence, enforcement of the law relies on people to report cases. In 1997, the CNLPE was assigned a permanent secretariat and a budget, and the practice of FGM/C was made subject to penal sanctions. The law imposes a prison sentence of six months to three years or a fine on anyone who attempts or succeeds at performing, requesting, inciting, or morally supporting $\mathrm{FGM} / \mathrm{C}$; if a death results, the penalty is $5-10$ years. Maximum penalties would be imposed if the guilty party is a medical professional. Also, all those who know about such criminal activity will be fined if they fail to report it to authorities.

The UNFPA-UNICEF Joint Programme (2015) presents Burkina Faso's current enforcement of the law as a noteworthy model. Much sensitisation and training has been done in the various elements of the criminal justice system. Judicial hearings are not held in the capital but rather conducted by mobile tribunals near the community where the case originates. The prosecution and sentencing is public. Before taking up the case the judges discuss FGM/C and answer questions from the public. The courts promote discussion and dialogue on the practice and strengthen the connection of formal law to the local community, according to the report. Those found responsible are counselled by the courts, which results in some defendants becoming agents of change. Such methods are consistent with the ideas of restorative justice which is a recent approach to penal theory and ethics not frequently encountered in discussions of the criminalisation of FGM/C. According to Boyes-Watson (2014), restorative justice seeks to build partnerships to re-establish mutual responsibility for constructive responses to wrongdoing within our communities. Restorative programmes seek a balanced approach to the needs of the victim, wrongdoer, and community through processes that preserve the safety and dignity of all). This increases the number of cases reported, and police are trained to take cases reported by the SOS Excision Hotline directly to health services for treatment. Therefore, Burkina Faso sometimes enforces its $\mathrm{FGM} / \mathrm{C}$ law in a way reminiscent of the restorative justice model.

In 2018, the government of Burkina Faso revised its FGM/C law, which is embedded in the Penal Code. Now, prison sentences range from 1-10 years and fines range from 500,000 to 3 million francs CFA [845 to 5060 USD]. If a girl dies following the cutting, imprisonment ranges from 1121 years and the fine is 1 million to 5 million francs CFA [1687 to 8432 USD]. A new article (art. 513-9) was added to discourage public support of the practice of FGM/C: "the penalty shall be imprisonment for a term of one to five years and a fine of two hundred fifty thousand $(250000)$ to one million (1000 000) CFA francs [422 to 1687 USD], whoever through his public speech, public comments or writing, encourages female genital mutilation" (Ministry of Justice, Human Rights and Civil Promotion, 2018: 148). The CNLPE is also pursuing its actions to fight against FMG/C in Burkina Faso by judging culprits through mobile courts and other actions at the national and community level, according to its five-year action plan (CNLPE 2016b). This shift is more punitive for those who persist in contravening the law, but the approach-through communication and sensitisation-is maintained and reinforced. Prosecutions are judged under this revised law, though the CNLPE does not yet have the figures to assess the actual shift since the law modification was recent.

\section{Mali}

Mali, in West Africa, is a landlocked country of 18 million people. FGM/C prevalence is high, with about $91 \%$ of women aged 15-49 years reportedly cut as of 2012-2013 (INFO-Stat/Mali and ICF International 2014). The type of FGM/C mostly practised is the "cut, flesh removed" (28TooMany 2018), which represents WHO type I and type II. Unlike in Burkina Faso, there has been very little decline in prevalence of FGM/C in Mali since the first measures from DHS data back in 1950 (Engelsma, Mackie, and Merrell 2018). Civil society organisations and government ministries have proposed laws, but the National Assembly has declined to enact them. 
However, it should be noted that Penal Code Act No. 01-079, of 20 August 2001, contains certain provisions applicable to violence against persons in general and could apply to cases of FGM/C. Indeed, reference should be made to articles 207 et seq. of the Criminal Code in this regard. In addition, the National Programme to Combat FGM/C in Mali [Programme National de Lutte Contre l'Excision au Mali] has undertaken many actions to combat the practice.

After an analysis of the Malian context since 1999, the Ministry of Health has also taken some measures to curb the practice. Through the Circular No. 0019/Msp-As-Sg, of 7 January 1999, the Minister of Health, the Elderly and Solidarity instructed all of the Regional Directors of Public Health and Directors of the Hospitals of Bamako and Kati, "to take all necessary measures to prevent the practice of FGC in health establishments under their moral and technical responsibility." It should be noted that the initiative for this instruction was based on the results of a survey carried out at that time, which showed a number of findings, including the following:

- $29 \%$ of women who have undergone FGM/C have difficulties in childbirth;

- $62 \%$ of health workers wanted a formal ban on FGM/C in health facilities;

- $28 \%$ thought that the practice should not be encouraged;

- $60 \%$ of the providers surveyed had already experienced the immediate complications of $\mathrm{FGM} / \mathrm{C}$ and $68 \%$ had experienced late complications.

\section{Theoretical underpinnings}

To explain variability in the effectiveness of criminal law in combatting FGM/C, we first needed to understand and investigate the reasons people have for obeying the law. People are motivated to obey the law for the following reasons (synthesised from Friedman 2016, Hart 1961, Kahan 1997, Mackie 2017, McAdams 2015, Tyler 1990):

- Moral:

- Personal agreement: following specific laws, believing they are morally right

- Legitimacy: believing that one owes general obedience to the law

- Procedural: believing that authorities apply the law fairly to all

- Social:

- Descriptive norm: Obeying/disobeying because others obey/disobey (including social proof and coordination)

- Injunctive norm: Shame among peers for disobeying the law, or pride for obeying

- Punitive:

- Fear of government punishment

- Or, more rarely, hope of government reward

- Religious

- We hypothesised that religious motivations take the form of moral agreement, or social approval by the religious community, or fear of punishment by the religious community

It is also useful to distinguish between obedience with respect to specific laws, and general obedience to the law. Obedience to many specific laws converges on general obedience, and a disposition to general obedience results in obedience to many specific laws. In all societies there are laws that most people do not obey; even in societies of high general obedience. For 
example, millions of youth pirate and exchange music files in violation of copyright law. We therefore study an individual's specific or general obedience, as well as that of the collective.

\section{Why criminalisation?}

A common policy response to $\mathrm{FGM} / \mathrm{C}$ is to call for enactment and enforcement of a criminal law to prohibit the practice. Why is criminalisation so often suggested as a remedy? First, FGM/C often involves caregivers acting on children so as to irreversibly reduce a valued human capacity (sexual functioning) in the absence of meaningful consent (Nussbaum 1999). If the change were reversible, or if it were made by a consenting adult, there would be little cause for concern. We know that many people value sexual experience, but the worry about FGM/C is not that women should pursue such experience, but rather that they should retain a free choice upon adulthood to do so or not (Nussbaum 1999). It is difficult for some people to understand or accept that those who practice FGM/C intend to help their daughters in one way or another, rather than to harm them. If caregivers intend to do wrong this this is a reason to apply criminal punishment.

Criminalisation is also suggested as a remedy because many in the developed world assume the doctrine of legal centralism: that in most places most people obey most laws and, hence, that the law is usually the best way to bring about social change and to reduce social harms. Yet, the law is often not obeyed around the world and law is not always the best way to bring about social change (Griffiths 1986). It is also true that people tend to think of themselves as motivated intrinsically, such as by moral considerations, and of others as having extrinsic motivation such as by the threat of social pressure or legal punishment (summarised with respect to motivations to obey the law by Feldman, 2011: 29-36). For instance, in Colombia, the nongovernmental organisation (NGO) Corpovisionarios has found that modal response for citizens' reasons for legal compliance is that "I obey the law for moral reasons, but that others obey the law to avoid legal penalties" (Guillot 2012). This common misperception may be why outsiders often believe that FGM/C practitioners would be more deterred by threats of punishment than by moral deliberations and social mobilisations.

Thus far, there have been no dramatic declines in the FGM/C attributable to law/regulation. There is an overall association at the national level between enactment of laws and a modest decline in self-reporting of the practice. Attribution of causality is difficult, however, because there is a modest decline in self-reporting in a range of countries, independent of legal prohibitions and enforcement of the same. Also, Burkina Faso may be an exception: the UNFPA-UNICEF Joint Programme (2015) considers its past and current enforcement of the law as a noteworthy model. Crisman et al. (2016), in a careful and sophisticated study, estimate that the 1996 passage of a law in Burkina Faso, in the context of many other efforts, reduced the risk of being cut by about $30 \%$. This is an encouraging finding that is likely attributable to the conjunction of various actions: a strong political will, the translation of the law into local languages, the mobile courts, the hotline, the involvement of community members and leaders, etc. (CNLPE 2016; UNFPA 2018).

Causality is also difficult to establish because enforcement is minuscule compared to the widespread nature of the practice: there have been 1,317 legal actions in 17 countries of focus from 2008-15, according to the UNFPA-UNICEF Joint Programme (2015). Criminalisation appears to have had limited effect, except for reports that it supports and bolsters organised social change. According to UNICEF (2013),

Debate on the efficacy of legislation banning FGM/C has been largely overtaken by a growing consensus that laws should be one of a set of interventions by governments to support a social movement towards its elimination. A UNICEF report on legislative reform and FGM/C notes that such reform needs to take into account the degree of social support for the practice..... In settings where 
segments of practising populations agree that girls and women should not undergo $\mathrm{FGM} / \mathrm{C}$, institutional frameworks can play an important role in supporting social change aimed at ending the practice....However, in communities with broad support for FGM/C, the challenge is to develop legislative reform strategies that complement efforts in the social sphere and contribute to collective abandonment of the practice.

That said, there is reason to believe the law has had some positive effects, which likely depend on implementation and social support. It seems to be important in Burkina Faso, and maybe in Benin, where the latest survey data show that the practice has fallen to near zero among those aged 0-10 years (although there are media reports of exceptions). Benin, like Burkina Faso, has conducted a variety of anti-FGM/C programmes (including law), but differs in that survey data show a much greater reduction in the practice.

\section{Why might criminalisation be ineffective?}

There are five main reasons why $\mathrm{FGM} / \mathrm{C}$ criminalisation may be ineffective in practising countries: (1) limited state capacity, (2) legal pluralism, (3) ineffective sanctions, (4) opposing moral and social motivations, and (5) widespread acceptance of the practice.

First, as a colonial legacy, states in sub-Saharan Africa tend to lack the capacity to strongly enforce basic law, never mind challenging laws like those associated with FGM/C. Yet, there remains an assumption among outsiders that various states can enforce such laws. For $F G M / C$, the state's role in fairly and effectively enacting, applying, and enforcing the law is especially important. Weak state capacity diminishes two of the moral reasons for complying with the law: the legitimacy of state commands and its procedural fairness in enforcing same.

Second, in the developed world, societies tend towards legal monism (a single legal authority) and in the developing world, particularly in sub-Saharan Africa, they tend towards legal pluralism (multiple legal authorities). Under legal pluralism, it is quite common for statutory law to exist alongside customary law.

What makes this pluralism noteworthy is not merely the fact that there are multiple uncoordinated, coexisting or overlapping bodies of law, but that there is diversity amongst them. They may make competing claims of authority; they may impose conflicting demands or norms; they may have different styles and orientations. This potential conflict can generate uncertainty or jeopardy for individuals and groups in society, who cannot be sure in advance which legal regime will be applied to their situation (Tamanaha 2008).

As European states centralised power and built state capacity, formal law over time came to displace previous reliance on custom. As these same states pursued imperial conquest, they imposed an alien formal law on their colonies, often relying on indirect rule that recognised the customary laws of indigenous peoples. The dual legalism naturally persisted after colonies gained independence. The United Kingdom's Department for International Development (DFID) estimates that in many developing countries, $80 \%$ of cases are settled within traditional or customary legal systems, which Tamanaha et al. (2012) calls an understatement. Legal pluralism does not imply a lack of legal authority, but multiple, conflicting authorities. To navigate in such a landscape, change agents must recognise the fact of legal pluralism where it exists and that customary and statutory law can harm both women's rights and interests. Harmonisation of authorities on morally justified ends is the appropriate response.

Third, the threat of punishment does not necessitate compliance. Indeed, Sherman (1993) suggests that "legal punishment either reduces, increases, or has no effect on future crimes, 
depending on the type of offenders, offenses, social settings, and levels of analysis." The same is true in the international arena. Political scientists have found that countries' ratification of human rights treaties does not necessarily improve respect for human rights (Neumayer 2005; Hathaway 2007). Worse, Hafner-Burton, Victor, and Lupu (2012, p. 80), in a nuanced review of the literature, observe that, "there is a troubling and recurrent finding that participation in some treaties correlates with worse human rights behaviour." Given such findings, it is not clear whether enactment of anti-FGM/C laws in practising countries predicts significant progress in abandonment of the practice.

Indeed, Shell-Duncan et al. (2013, p. 1), who studied criminalisation of FGM/C in Senegal, found that,

Among supporters of FGC [female genital circumcision], legal norms ran counter to social norms, and did little to deter the practise, and in some instances incited reactance or drove the practise underground. Conversely, where FGC was being contested, legislation served to strengthen the stance of those contemplating or favouring abandonment. We conclude that legislation can complement other reform strategies by creating an "enabling environment" that supports those who have or wish to abandon FGC.

In Ethiopia, which also has a strong and widely publicised criminal law against FGM/C, Boyden, Pankhurst, \& Tafere (2013) found that, for many respondents, the practise of FGM/C had gone underground and possibly become stronger in reaction to criminalisation. Girls who had opposed the practise changed as they approached the age of marriage because of peer pressure from older girls, and some girls demanded and organised FGM/C on their own, without their parents' knowledge, shielding their parents from prosecution. The authors conclude "that interventions to promote changes in practises that do not consider the underlying logic and potential unintended consequences for those affected are unlikely to achieve their aims and may engender resistance and result in adverse outcomes" (p. 42).

Fourth, moral and social reasons contribute strongly to compliance. Tyler's (1990, p. 45) pioneering Chicago-based study showed that self-reported legal compliance is correlated with morality, peer disapproval, and certainty of punishment). Summarising related literature, Nagin and Pogarsky (2001, p. 869) find that, "a belief that illicit conduct is wrong, and the fear of disapproval, embarrassment, or social stigma discourage offending behaviour." Further, "the conforming influence of extra-legal [moral and social] [is] far greater than that from legal sanctions" (Nagin and Pogarsky, 2001, p. 869); the effect sizes of variables having to do with the certainty and severity of legal punishment are "modest to negligible" (Pratt et al. 2006, p. 383), and variables related to the threat of force of extra-legal sanctions, such as moral conscience or social disapproval are "among the most robust predictors of deterrence" (Pratt et al. 2006, p. 385).

Additionally, law itself is held in place not only by moral and penal motives but, crucially, by social norms of general and/or specific legal obedience. In the absence of a social norm of legal obedience, popular compliance may be low. The social norm of legal obedience may be low for historical reasons: the illegitimacy of laws in prior conditions of colonial occupation or of communist rule may have obstructed the emergence of such a norm. Sometimes the lack of a legal obedience social norm may reflect popular opposition or indifference to a particular law; sometimes general legal disobedience can exist among a minority of "legal nihilists" who pride themselves on defiance. And, importantly, the absence of a legal obedience social norm may be driven by obedience to conflicting customary law. 
Fifth, criminal law is designed to regulate harmful deviance at the margins of social consensus (Mackie 2017), not socially acceptable behaviour. Dowry murder, for example, is a deviation from an accepted norm, with intended harmful consequences perpetrated by a few specific individuals and with a backwards-looking remedy: punishment of the guilty. Dowry itself, while also sometimes harmful, is situated differently: it is an accepted norm, associated with often indirect and unintended harmful consequences, that is carried by many, and is associated with a forwards-looking remedy: coordinated abandonment. It should not be surprising, then, that dowry is criminalised, without effect, in India (Mackie 2017). Enforcement would require jailing most of the population and law enforcers, who have limited resources and discretion, pursue crimes that they and the local community most want to be punished. Citizens do not obey anti-dowry laws because they expect the law to approximate popular views, thus undermining the general and particular legitimacy of the law. Why obey, if others do not?

Relatedly, Aldashev et al. (2012) find that a moderate law can increase the bargaining power of a local person governed by customary law who can credibly threaten to move a dispute to the formal, legal arena, thereby obtaining a local settlement more in her favour. Under these constraints, the law acts as a magnet, moving custom in its direction. An extreme law, that most believe to be enforceable, however, has no such magnet effect. Platteau (2010) confirms this finding in varying contexts across sub-Saharan Africa, suggesting that the social acceptability of $\mathrm{FGM} / \mathrm{C}$ may, in some contexts, undermines the effectiveness of the law.

Where conditions are favourable for international law, state compliance with international law, and states' ability and will to enforce the law, such as in the United Kingdom or France, it is not clear how effective criminalisation of $\mathrm{FGM} / \mathrm{C}$ has been. If arrest, prosecution, conviction, and punishment for violation cause deterrence, there have been few such actions (Berer 2015) in these countries.

\section{Study aim, research questions and objectives}

The overall aim of the cross-border study along the Burkina Faso and Mali border was to understand how to better use criminal law to help bring an end to the practise of $F G M / C$. Understanding the motivations and causes that lead the citizens of Mali and Burkina Faso to obey the law was a key secondary aim of the research.

Overall, the cross-border study sought to answer these questions:

1. How much do citizens obey laws prohibiting them to practise $F G M / C$ ?

2. Among people born into a tradition of FGM/C, what are the reasons and causes that motivate them to obey or not a law prohibiting FGM/C?

3. What are the moral, social, and punitive reasons that influence people to obey rules of conduct, the law in general, and, in particular, FGM/C law?

4. What other reasons influence the choice to cut or not?

5. How does the design and administration of legal implementation affect their choice to obey?

6. Given the findings, what legal policy and programme responses, across varying contexts, would most effectively reduce the practise of FGM/C?

The design and conduct of the research aimed to achieve these objectives:

1. Measure the extent of legal obedience by literature review, limited inferences from DHS and Multiple Indicator Cluster Surveys (MICS) data (including methods to detect depressed selfreport), and qualitative and quantitative interviews and experiments in two countries.

2. In those two countries, conduct local qualitative and quantitative studies, and in two countries larger quantitative studies, aimed at finding reasons people give for obeying laws and the 
$\mathrm{FGM} / \mathrm{C}$ law.

3. In those same studies, find out what nonlegal reasons people give for cutting or not cutting.

4. In those same studies, and for quantitative studies-small add-ons involving local officials and notables - find out how the content of the law, the design of its implementation, and the actual administration of its implementation affects compliance with FGM/C law. Desk review of the history, content, and implementation of $\mathrm{FGM} / \mathrm{C}$ law in a given country.

5. Synthesise study findings and relate them to policy and programme issues.

\section{Methods}

\section{Study design}

We used a mixed-method design, involving quantitative and qualitative surveys that were implemented on the basis of a border-discontinuity.

In the structured quantitative study, we randomly sampled two groups of people, aged 18 years and older, in each of six villages. We gathered the usual demographic data to test for the requisite homogeneity across paired communities. To overcome the social desirability bias often associated with questions that require self-reporting, we used a list experiment/unmatched count technique, a method known for assuring respondents of confidentiality and disguising the respondent's actions or attitudes from the researcher and any other party. The unmatched count technique (Dalton, Wimbush, and Daily 1994) is designed in a manner such that it is clear to the respondent that no one can detect whether s/he committed the sensitive act being investigated. Unmatched count requires two large enough random samples of the population. Respondents in the control sample are presented, for example, with four benign or neutral activities and asked whether they have engaged in them anytime in some fixed period. They are to count the number of activities they did at least once and report the total, but to say nothing more. Respondents in the treatment sample are presented with those first four activities plus, say, cutting of girls by the family, and asked to count the number of activities they did at least once and report the total. The two random samples are compared and the number of people doing FGM/C can be deduced by subtracting the number of yes answers in the control condition from the number of yes answers in the treatment condition, and there is no way that anyone can identify any individual who performed the sensitive action. Unmatched count consistently yields higher reports of sensitive activity than self-report.

The qualitative component was composed of Key Informants Interviews (KIls) and Focus Group Discussions (FGDs). Key informants were purposively selected from various positions within the chosen communities in order to understand participants' opinions about the moral, social, and legal rules in the community. The FGDs aimed to elicit indirect responses to prompts on statutory law in general: vignettes on FGM/C and heterogeneous contrast practises such as theft of crop, rape, and a land inheritance dispute. Each vignette was designed to elicit typical moral, social, legal, and religious reasons people have for complying or not with a rule; what authority (conscience, family, chief, police, etc.) the typical person would turn to and why; typical experience with police and courts, if any; and how to improve resolution of problems.

An example of vignette was: "The Konaté family has a young daughter, Monique. Her family is considering circumcision. The family has heard many different things for and against the practise: from their relatives, traditional and religious leaders, radio, nurses, teachers, government, NGOs and from others. After talking it over, they decide it is better for her NOT to be cut.

1. What did they believe would happen if the girl were NOT cut?

2. What reasons did they consider for NOT cutting her? 


\section{Study sites}

We selected three matched communities on each side of the border. The criteria for selection were: 1) presence of the same dominant ethnic group; 2) high FGM/C according to Burkina Faso and Mali DHS data among many from the dominant ethnic group; and 3) paired communities no more than $50 \mathrm{~km}$ apart and reachable. The paired communities in the study were: Faramana (Burkina Faso)/Koury (Mali); Tansila (Burkina Faso)/ Boura (Mali); and Finkolo (Mali)/Koloko (Burkina Faso). A different ethnicity is dominant in each of these three cross-border sites. The Bobo, Senoufo, and Bwaba were the three majority ethnic groups belonging respectively to the above three pair villages. Given the mobility of the population, some participants of the quantitative survey were from other ethnic groups (e.g. Peulh, Mossi).

Figure1: The three pair sites along the Burkina Faso and Mali Border

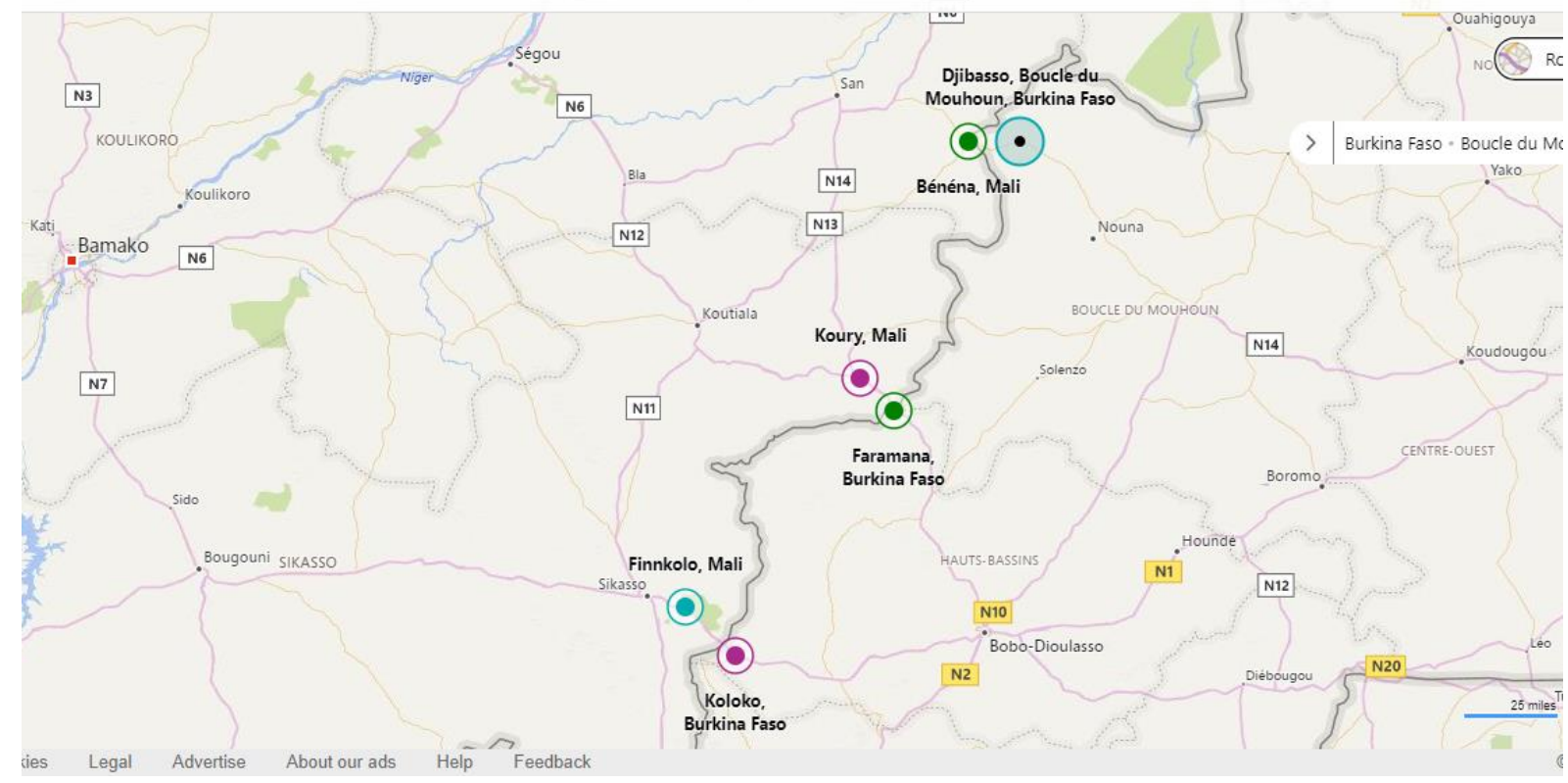

\section{Participants}

The qualitative participants were composed of two types of informants. Key informants were composed of notables, such as community leaders, religious leaders, women's leaders, government officials, health workers, local NGOs, and teachers; purposively identified based on their knowledge of and experiences with compliance with moral, social, and legal rules in the community, and people's experiences with traditional justice, police, and the courts. We conducted semi-structured individual interviews among notables about their experiences with community regulation and ideas related to what could be done better. They were identified with an eye towards diversity of role within the community. Focus group discussions participants were comprised of four groups: Men aged 18-34 years, Men 35+ years, Women 18-34 years, and Women $35+$ years. Four FGDs with 6-7 participants were conducted in each village. We recruited participants through community facilitators in each village to ensure diversity and inclusion. We asked them to assist the qualitative team leader to recruit participants widely. Our team leader was present during the whole process of the participants recruitment. In total, 7-10 in-depth interviews with key informants and four discussions (FGDs) with adult respondents were conducted in each village. This represents a total of 60 KIls and 24 FGDs carried out in the six villages. 
The quantitative survey participants included men and women over 18 years of age. We targeted 200 adult respondents per village and, ultimately, a total sample of 1209 individuals were surveyed, including 605 men and 604 women. The survey participants were recruited using a right-hand rule randomization for selecting households and the Kish method for selecting individual participants. Given the dearth of information about the sample frame in the study location, we chose to proceed with a sampling strategy that included randomisation at multiple levels. The exact procedure used is as follows: Upon arriving in a village, Team Leaders communicated with the village chief about the number and geographical arrangement of various neighbourhoods or localities. The Team Leaders then split the team up so as to have a starting point in each neighbourhood/locality. Data collectors started from a common point in each locality and fanned out in opposite directions using the right-hand rule technique. A random number from 2-6 was chosen each day and data collectors counted the number of houses/compounds as they moved away from their common starting point, stopping when they arrived at the house/compound that was equal to the randomly selected number.

After entering the house/compound, the data collector then determined whether he or she was dealing with a house or compound. If it was a house, the enumerator would proceed with an electronic Kish-method sampling technique to select one male and one female respondent in that household. This technique requires inputting all residents of the household (as defined above) and their genders into the survey platform via tablet. The survey platform then chose the male and female respondent who would be asked to complete the survey. If one or both of the respondents refused to participate, there was no replacement within the household. Instead, if one respondent was willing to participate, the enumerator would interview that respondent and then move on to the next household. If no respondents were willing to proceed, the enumerator would move on, without conducting any interviews in the household, to the next household (selected by counting houses until reaching the "number of the day" once again).

If the enumerator found a compound rather than a household, the enumerator would move around the compound to the right (circling counter-clockwise) and count the households in the compound until he or she once again got to the randomly selected "number of the day". It is in this household that the enumerator would proceed with the Kish-method sampling technique described above. Once any interviews conducted in this household were complete, the enumerator would continue counting households until he/she arrived at the next house that corresponded to the "number of the day." The enumerator would then start counting households inside a given compound, if there were any households left that had not been counted, before proceeding to count houses/compounds outside of the compound.

As the data collectors proceeded, counting houses and conducting interviews, they made right turns at all intersections. When conducting interviews in the same village on subsequent days, data collectors would start from different starting points, as selected by the Team Leader, and follow the approach outlined above while again using a randomly selected "number of the day" for household counting purposes.

\section{Instruments}

The qualitative instruments consisted of 1) a key informant interview guide; and 2) a semistructured interview guide. The latter included a variety of vignettes. We chose to proceed in this manner because topics such as reasons for compliance or noncompliance with customary and statutory rules, and experiences with police and courts, require counterfactual reasoning. Vignettes helped to collect the richest and most informative data possible on why people comply with the law or not. The vignettes elicited typical moral, social, legal, and religious reasons 
people have for complying or not with a rule; what authority (conscience, family, chief, police, etc.) the typical person would turn to and why; typical experience with police and courts, if any; and how to improve resolution of problems.

For the quantitative survey, we utilised a questionnaire that included a "list experiment," which is a technique used to elicit truthful responses on sensitive questions. In the context of this study, we wanted to collect truthful responses about whether or not one planned to continue practising $\mathrm{FGM} / \mathrm{C}$.

Several of the topics covered on the qualitative survey overlapped to some degree with the individual quantitative questions, allowing for some comparison with group effects in the focus group discussion and individual experiences and knowledge from the Klls. The quantitative and qualitative research instruments were developed and pre-tested in the capital of Burkina Faso, Ouagadougou. They were then revised, before data collection began, but after the data collectors were trained and had conducted the pilot. The interviews were conducted mostly in the local language Dioula (except with the government representatives), and the local translation for the French term "excision," which is also used in the national policy (in Burkina Faso) and sensitisation campaigns in both countries.

\section{Procedures}

The quantitative data were collected electronically using Survey Solutions, an electronic data collection application, on tablets running the Android Operating System. After the programmer designed the survey on the Survey Solutions platform, a server request was made in order to reserve a server for data storage. The questionnaire was then loaded on the server and profiles for data collectors and supervisors were created. Finally, the questionnaire was "assigned" to the data collectors to allow them to utilise the questionnaire on their smartphone. A one-day pilot field test was done to test the tool and the logistics of community entry.

After verification by Team Leaders, collected data were transmitted to a data server in real time. Data quality control was implemented in several ways. First, many possible response options were programmed into the tablets and all consistency and validity checks were built into the programme. Second, each team of data collectors was supervised by a Team Leader who was tasked with the responsibility to check the data for quality and ensure randomisation rules were followed correctly. Third, the research team also conducted monitoring visits and spot checks and made calls to the field teams to ensure quality and proper consenting procedures were followed. Fourth, the data management team also conducted weekly data quality checks on the data transmitted to the server; suspected errors and inconsistent or invalid data were then flagged and dealt with. This included ensuring that no duplicate entry was transmitted to the server. And, last but not least, an automated weekly data-collection progress report was generated on a few key indicators and shared with the research team to ensure that data were collected in the way it was envisaged to be collected. After all data were collected and sent to the server, data cleaning was conducted on all variables, all variables were labelled, and their coded categorical variable-assigned values were labelled.

On the qualitative side, participants were recruited through local facilitators, who, in turn, were identified in each village during the PI field visits. During data collection, those facilitators assisted the qualitative Team Leader in identifying key informants. These Key Informants were either representatives from the Ministry of the Family, a Village Development Council (CVDConseil villageois de dévelopement), a representative of a local NGO, or a local leader. During data collection, Team Leaders (two were designated for each village, depending on their familiarity with the study sites, to be the spokespersons for the group) were guided by these 
facilitators to get in touch with potential participants while also seeking diversity of role. The same procedure was used in recruiting focus group participants. The FGD participants were reimbursed for their transport fees (2000 FCFA), but KIls were not. The qualitative interviews and focus group discussions were audio-recorded. Participants' permission was obtained before recording. The 24 days of data collection went smoothly and there were no major security problems for data collectors or incidents of distress from research participants during interviews. The only challenge was the reserve some FGD participants displayed with respect to the FGM/C theme. The data collectors were instructed to motivate participants and probe for further information, but also to be able to move to next questions when participant(s) were refusing or seemed uncomfortable about answering a specific question. Some reluctance to talk about FGM/C was present, however, and this must be taken into consideration as one interprets our analysis.

\section{Data analysis}

\section{Quantitative data analysis}

Data were analysed in STATA 14, and results are presented below in tables and graphs. Categorical variables were analysed using descriptive frequency distributions and two-way cross tabulations. Where necessary, both the numbers and proportions are presented, otherwise only percentages are shown. Numerically collected variables were summarised using median as a measure of central tendency and inter-quartile range (IQR) as a measure of variability for skewed variables or mean and standard deviation as a measure of central tendency and variability, respectively, for approximately normally distributed variables.

A list experiment was used to estimate planned future prevalence of $F G M / C$. List experiments allow researchers to ask about sensitive topics because there is no way for the researcher to know if any individual respondent is associated with the sensitive activity. Each respondent simply reports a number of items that are true for him or her. In this case, a control group of respondents was given a list of five nonsensitive activities, while a treatment group was given a list of six activities, the five nonsensitive ones and the following: "Circumcise my daughter or granddaughter," Researchers do, however, have access to the statistics associated with the entire sample and can infer group behaviour from same. In this case, we were able to calculate the proportion of respondents in the treatment group who planned to "circumcise their daughter or granddaughter."

\section{Qualitative Data Analysis}

The audio-recordings of the $60 \mathrm{KIIs}$ and 24 FGDs were transcribed and translated into French by the six qualitative RAs who collected the data. The PI did a quality check to review and validate a sample of the transcripts. After that, the qualitative Team Leader quality-checked all transcripts for typos and language. This was particularly important given the fact that the transcripts were to be translated into English. Any language issue was reported to the PI who provided corrections. The PI translated a sample of 2 KIIs and 2 FGDs into English for the co-PI. They both read them closely and coded the sample transcripts to elicit emerging patterns. They then cross-checked patterns and developed a thematic coding framework, using both an inductive (from the data) and deductive (from the research instruments) approach. Once the quantitative results were ready, PI Wouango and the co-PI reviewed and refined the thematic coding framework.

Four qualitative data analysts were then recruited in Senegal to code the qualitative data using Nvivo. They received a two-and-half-day training on the research rationale, the study sites, and the context-specific aspects of the research that were essential for them to be able to understand 
the verbatim language in the transcripts. The transcripts were then coded in batches. The analysts coded transcripts of the first paired villages and their coding were quality-checked by the $\mathrm{PI}$, who had Skype meetings with the analysts to provide feedback and respond to their queries. These meetings were indispensable to clarify the coding guidelines and to limit variations in the analysts' coding style. A second batch of two paired village transcripts were then coded and a Skype call was used to discuss any issues. The FGD transcripts were the last batch to be coded.

The personal information identifying the qualitative study participants (i.e. role of KIls within the community, gender, age) were removed and transcripts were anonymized before analysis. A separate Excel file was produced to keep a record of this sensitive information. The file is kept in the Principal Investigator's computer and only she has access to it.

\section{Ethical considerations}

The research protocol described herein submitted to and obtained ethical approvals from the Population Council Institutional Review Board, the Burkina Faso Ministry of Health's Research Ethics Committee, and the Mali Ministry of Health's Research Ethics Committee. Before the interviews could begin, all participants received informed consent forms (which were requested by Burkina Faso IRB). Willing participants then signed (or fingerprinted) the form when they agreed to participate, indicating that they understood the aim of the research and willingly agreed to participate in it. Participants also received a copy of the consent form for their records.

\section{Results}

This section presents the results of the study under the following broad themes: types of disputes and conflict-resolution mechanisms, knowledge about legality/illegality of $\mathrm{FGM} / \mathrm{C}$, sources of information of formal and customary law, the list experiment, prevalence estimation from the list experiment, compliance motivations, religious and traditional obligations regarding $\mathrm{FGM} / \mathrm{C}$, knowledge of $\mathrm{FGM} / \mathrm{C}$ practise as compared with other criminalised conduct, engendered knowledge of $F G M / C$, reasons for practise of $F G M / C$, continuation/discontinuation of $F G M / C$, awareness of social cost of FGM/C, and the endorsement experiment. In the FGM/C knowledge and practise sections we compare $\mathrm{FGM} / \mathrm{C}$ with other criminalised activities like cutting wood in the forest or bush and paying police a bribe to avoid getting into trouble to demonstrate the hypothesis that people tend to underreport $\mathrm{FGM} / \mathrm{C}$ because $\mathrm{FGM} / \mathrm{C}$ is rooted in community customs while the other two are not.

The study utilises mixed methods, both quantitative and qualitative, to arrive at its conclusions. Qualitative data are used either to confirm/contradict the results from the quantitative study or to explain in more detail the contexts and the processes of participants' experiences and perspectives. 


\section{Socioeconomic and demographic characteristics of participants}

\section{Quantitative research participants}

A total of 1,209 participants were interviewed, 603 in Burkina Faso (50\% male, $50 \%$ female) and 606 in Mali (50\% male, 50\% female). A total of three communes from each country were targeted for interviews. There were 203 respondents (who completed interviews) from Faramana, 200 from Koloko, and 200 from Tansila on the Burkina Faso side; and 202 from Koury, 201 from Finkolo, and 203 from Boura on the Mali side. The socio-demographic characteristics of the survey respondents are summarized in Table 1.

Table 1: Demographic characteristics of respondents interviewed in Burkina Faso and Mali, by gender

\begin{tabular}{|c|c|c|c|c|c|c|}
\hline & \multicolumn{3}{|c|}{ Burkina Faso } & \multicolumn{3}{|c|}{ Mali } \\
\hline & $\begin{array}{l}\text { Male } \\
N=301\end{array}$ & $\begin{array}{l}\text { Female } \\
N=302\end{array}$ & $\begin{array}{l}\text { Total } \\
\mathrm{N}=603\end{array}$ & $\begin{array}{l}\text { Male } \\
N=304\end{array}$ & $\begin{array}{l}\text { Female } \\
N=302\end{array}$ & $\begin{array}{l}\text { Total } \\
N=606\end{array}$ \\
\hline & $n(\%)$ & $n(\%)$ & $n(\%)$ & $n(\%)$ & $n(\%)$ & $n(\%)$ \\
\hline Age (median [IQR]) & $\begin{array}{c}38 \\
(30,51)\end{array}$ & $\begin{array}{c}30 \\
(24,41)\end{array}$ & $\begin{array}{c}34 \\
(26,46)\end{array}$ & $\begin{array}{c}40 \\
(30,50)\end{array}$ & $\begin{array}{c}34 \\
(24,43)\end{array}$ & $\begin{array}{c}36 \\
(27,47)\end{array}$ \\
\hline \multicolumn{7}{|l|}{ Pair communes } \\
\hline Faramana & $100(33.2)$ & $103(34.1)$ & $203(33.7)$ & - & - & - \\
\hline Koury & - & - & - & $102(33.6)$ & $100(33.1)$ & 202 (33.3) \\
\hline Koloko & $101(33.6)$ & $99(32.8)$ & $200(33.2)$ & - & - & - \\
\hline Finkolo & - & - & - & $100(32.9)$ & $101(33.4)$ & $201(33.2)$ \\
\hline Tansila & $100(33.2)$ & $100(33.1)$ & $200(33.2)$ & - & - & - \\
\hline Boura & - & - & - & $102(33.6)$ & $101(33.4)$ & $203(33.5)$ \\
\hline \multicolumn{7}{|l|}{ Ethnicity } \\
\hline Bobo & $56(18.6)$ & $59(19.5)$ & $115(19.1)$ & $52(17.1)$ & $61(20.2)$ & $113(18.6)$ \\
\hline Senoufo & $75(24.9)$ & $75(24.8)$ & $150(24.9)$ & $90(29.6)$ & $91(30.1)$ & $181(29.9)$ \\
\hline Mossi & $81(26.9)$ & $80(26.5)$ & $161(26.7)$ & $12(3.9)$ & $5(1.7)$ & $17(2.8)$ \\
\hline Peulh & $21(7.0)$ & $22(7.3)$ & $43(7.1)$ & $17(5.6)$ & $22(7.3)$ & $39(6.4)$ \\
\hline Bwaba & $5(1.7)$ & $7(2.3)$ & $12(2.0)$ & $14(4.6)$ & $12(4.0)$ & $26(4.3)$ \\
\hline Other & $63(20.9)$ & $59(19.5)$ & $122(20.2)$ & $119(39.1)$ & $111(36.8)$ & $230(38.0)$ \\
\hline \multicolumn{7}{|l|}{ Marital Status } \\
\hline Never married & $36(12.0)$ & $19(6.3)$ & $55(9.1)$ & $33(10.9)$ & $13(4.3)$ & $46(7.6)$ \\
\hline Ever married & $265(88.0)$ & $283(93.7)$ & $548(90.9)$ & $271(89.1)$ & $289(95.7)$ & $560(92.4)$ \\
\hline $\begin{array}{l}\text { Live in same household with } \\
\text { parents/parents-in-law }\end{array}$ & $136(45.2)$ & $131(43.4)$ & $267(44.3)$ & $163(53.6)$ & $126(41.7)$ & $289(47.7)$ \\
\hline \multicolumn{7}{|l|}{$\begin{array}{l}\text { Who makes decisions about } \\
\text { money }\end{array}$} \\
\hline You & $229(76.1)$ & $19(6.3)$ & $248(41.1)$ & $231(76.0)$ & $29(9.6)$ & $260(42.9)$ \\
\hline Your spouse & $8(2.7)$ & $222(73.5)$ & $230(38.1)$ & $8(2.6)$ & $229(75.8)$ & 237 (39.1) \\
\hline $\begin{array}{r}\text { You and your spouse } \\
\text { together }\end{array}$ & $6(2.0)$ & $8(2.6)$ & $14(2.3)$ & $11(3.6)$ & $9(3.0)$ & $20(3.3)$ \\
\hline
\end{tabular}




\begin{tabular}{|c|c|c|c|c|c|c|}
\hline & \multicolumn{3}{|c|}{ Burkina Faso } & \multicolumn{3}{|c|}{ Mali } \\
\hline & $\begin{array}{l}\text { Male } \\
N=301\end{array}$ & $\begin{array}{l}\text { Female } \\
N=302\end{array}$ & $\begin{array}{l}\text { Total } \\
N=603\end{array}$ & $\begin{array}{l}\text { Male } \\
N=304\end{array}$ & $\begin{array}{l}\text { Female } \\
N=302\end{array}$ & $\begin{array}{l}\text { Total } \\
N=606\end{array}$ \\
\hline & $n(\%)$ & $n(\%)$ & $n(\%)$ & $n(\%)$ & $n(\%)$ & $n(\%)$ \\
\hline Your in-laws & $2(0.7)$ & $15(5.0)$ & $17(2.8)$ & $4(1.3)$ & $16(5.3)$ & 20 (3.3) \\
\hline Other & $56(18.6)$ & $37(12.3)$ & $93(15.4)$ & $50(16.4)$ & $19(6.3)$ & $69(11.4)$ \\
\hline \multicolumn{7}{|l|}{ Number of children } \\
\hline None & $45(15.1)$ & $33(11.0)$ & $78(13.0)$ & $38(12.5)$ & $23(7.6)$ & $61(10.1)$ \\
\hline 1-3 children & $96(32.1)$ & $132(43.9)$ & $228(38.0)$ & $92(30.3)$ & $114(37.7)$ & $206(34.0)$ \\
\hline 4-8 children & $116(38.8)$ & $130(43.2)$ & $246(41.0)$ & $129(42.4)$ & $147(48.7)$ & $276(45.5)$ \\
\hline 9 or more & $42(14.0)$ & $6(2.0)$ & $48(8.0)$ & $45(14.8)$ & $18(6.0)$ & $63(10.4)$ \\
\hline \multicolumn{7}{|l|}{$\begin{array}{l}\text { Duration of stay in the } \\
\text { community }\end{array}$} \\
\hline$<1 \mathrm{yr}$. & $2(0.7)$ & $5(1.7)$ & $7(1.2)$ & $2(0.7)$ & $6(2.0)$ & $8(1.3)$ \\
\hline $1-5 y r s$ & $16(5.3)$ & 37 (12.3) & $53(8.8)$ & $9(3.0)$ & $18(6.0)$ & $27(4.5)$ \\
\hline$>5$ & $117(38.9)$ & $142(47.0)$ & $259(43.0)$ & 95 (31.3) & $142(47.0)$ & $237(39.1)$ \\
\hline Since birth & $166(55.1)$ & $118(39.1)$ & $284(47.1)$ & $198(65.1)$ & $136(45.0)$ & $334(55.1)$ \\
\hline \multicolumn{7}{|l|}{ Religion } \\
\hline Islam & $224(74.4)$ & $222(73.5)$ & $446(74.0)$ & $246(80.9)$ & $245(81.1)$ & $491(81.0)$ \\
\hline Catholic & $18(6.0)$ & $20(6.6)$ & $38(6.3)$ & $24(7.9)$ & $26(8.6)$ & $50(8.3)$ \\
\hline Protestant & $11(3.7)$ & $18(6.0)$ & $29(4.8)$ & $5(1.6)$ & $7(2.3)$ & $12(2.0)$ \\
\hline Traditional & $47(15.6)$ & $32(10.6)$ & $79(13.1)$ & $28(9.2)$ & $22(7.3)$ & $50(8.3)$ \\
\hline Other & $1(0.3)$ & $9(3.0)$ & $10(1.7)$ & $1(0.3)$ & $0(0.0)$ & $1(0.2)$ \\
\hline
\end{tabular}

The median age of respondents was 34 in Burkina Faso (38 for males and 30 for females) and 36 in Mali (40 for males and 34 for females). About 9 out of $10(91 \%)$ and $92 \%$ of the respondents from Burkina Faso and Mali, respectively, had ever been married at the time the survey was completed; meanwhile, $45 \%$ of those from Burkina Faso and $48 \%$ of those in Mali lived in the same house with their parents/parents-in-law. With regard to decision-making about money, there was clear variation by sex in both countries, where slightly more than threequarters of the male respondents $(76 \%)$ said they made the decisions themselves, compared to less than $10 \%$ of their female counterparts. Slightly below half $(47 \%)$ of the respondents from Burkina Faso and more than half $(55 \%)$ of the respondents from Mali had lived in the area where interviews were conducted since birth, with the proportion of males in this category being higher in both countries (Table 1). Three-quarters (74\%) and four-fifths (80\%) of the respondents from Burkina Faso and Mali, respectively, were Muslim, while $6 \%$ in Burkina Faso and $8 \%$ in Mali practised Catholicism.

\section{Qualitative research participants}

Qualitative research participants were comprised of 60 key informants (males and females aged 18 and over) and 6-7 participants, both males and females, aged 18 years and over for each of the 24 focus groups discussions 
Table 2: Number of interviews conducted per village

\begin{tabular}{|l|c|c|c|c|c|c|c|}
\hline $\begin{array}{l}\text { Type of } \\
\text { interview }\end{array}$ & $\begin{array}{l}\text { Faramana } \\
(\mathrm{BF})\end{array}$ & $\begin{array}{l}\text { Koury } \\
(\text { Mali })\end{array}$ & $\begin{array}{l}\text { Koloko } \\
(\mathrm{BF})\end{array}$ & $\begin{array}{l}\text { Finnkolo } \\
\text { (Mali) }\end{array}$ & $\begin{array}{l}\text { Tansila } \\
(\mathrm{BF})\end{array}$ & $\begin{array}{l}\text { Boura } \\
\text { (Mali) }\end{array}$ & Total \\
\hline $\begin{array}{l}\text { Key Informant } \\
\text { Interviews }\end{array}$ & 11 & 12 & 12 & 7 & 10 & 8 & $\mathbf{6 0}$ \\
\hline $\begin{array}{l}\text { Focus Group } \\
\text { Discussions }\end{array}$ & 4 & 4 & 4 & 4 & 4 & 4 & $\mathbf{2 4}$ \\
\hline
\end{tabular}

Most of the key informants were civil servants (35) who had some level of education. The remaining (25) were local leaders, such as village chiefs, imams, priests, CVDs, and representatives of local NGOs and youth and women movements. The FGD participants were mostly villagers with little or no education.

\section{Types of Disputes and Conflict Resolution Mechanisms}

\section{Types of disputes}

The data shed light on some of the most common types of disputes among the population we surveyed. Overall, out of all people interviewed, the most reported types of disputes were conflicts over land (47\%) and conflicts between breeders and farmers $(27 \%)$. Nine percent of the respondents cited conflicts relating to culture, traditions, and customs, while $3 \%$ reported ethnic conflicts. Other responses included domestic conflicts and conflicts around child marriage. In Figure 2 these results are disaggregated by country and by gender for each country.

Figure 2: Type of conflicts along the Burkina Faso and Mali border

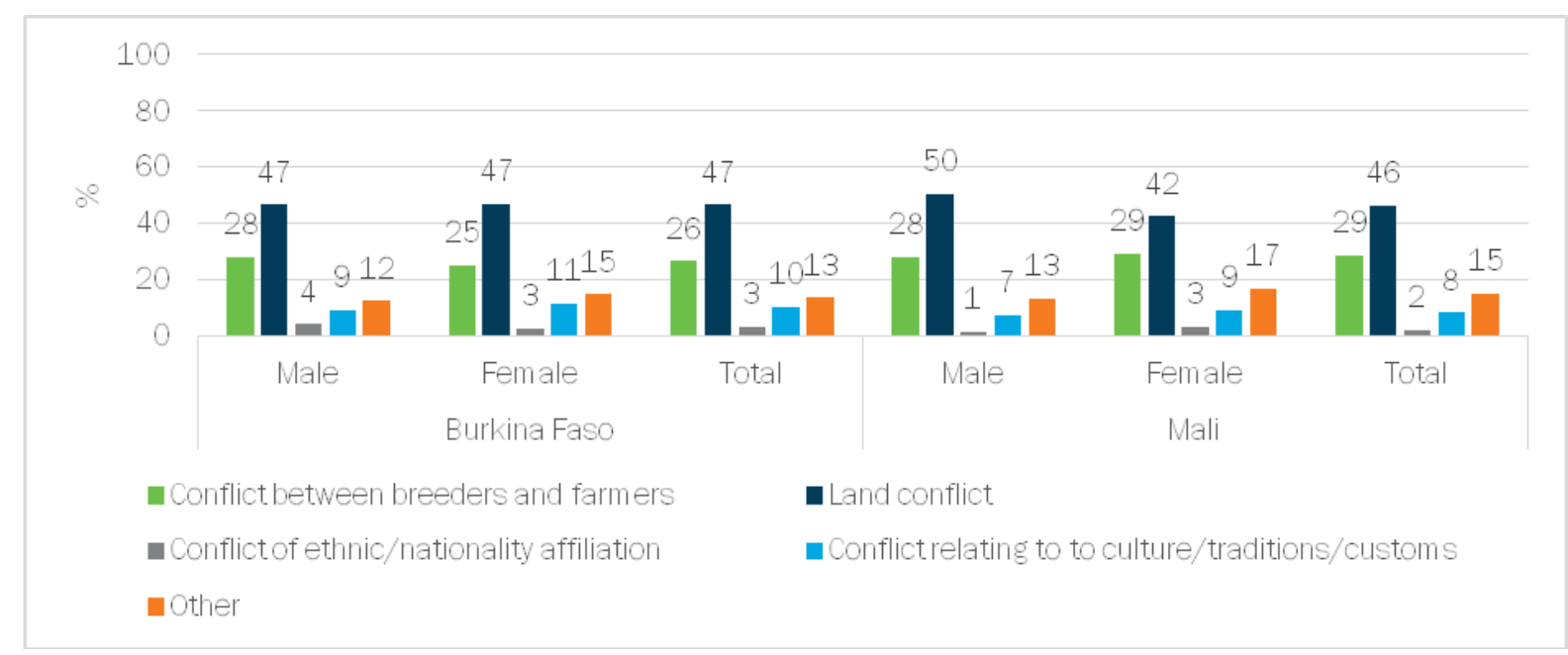

As evidenced by Figure 2 above, conflicts over land were the most common type of conflict in both Burkina Faso (47\%) and Mali (46\%), followed by conflicts between breeders, which were cited by slightly over a quarter of the respondents in both Burkina Faso and Mali. Conflicts relating to culture, traditions or customs were cited by about one in 10 of the respondents in both countries.

Appendix Table 1 shows paired commune variations in terms of both types of disputes and existing conflict resolution mechanisms. In these results, we compare Faramana (Burkina Faso) 
and Koury (Mali), Koloko (Burkina Faso) and Finkolo (Mali), and Tansila (Burkina Faso) and Boura (Mali). Results show that there were no significant differences between the pair communes but there existed gender differences within some communes. These results serve as a balance test on this issue.

Importantly, the qualitative findings differ from the quantitative results on types of conflicts experienced. Child and early marriage and women's abduction were cited as the second- or third-most common types of disputes in the qualitative data. Child marriage is widespread in all communities, regardless of country. It is practised by the three ethnic groups equally (Bobo, Senoufo and Bwaba) in Burkina Faso and Mali and people justify it as being a common way that couples are formed. Child and early marriage can be arranged (parents give the girl without her consent), forced (the girl is kidnapped by a man/boy without her consent or the consent of her parents), or wanted (a girl flees with her boyfriend, sometimes to avoid an arranged marriage). The Senoufo community even has a word, "Kosseguê," to describe this practice: a woman who is married has to send her first girl child back to her parents' house to be married there. The law on age of marriage was almost unknown by most FGD respondents. The corpulence of the girl, the fact that she has menstruated, and the fact that she has developed breasts are indicators parents look for when deciding when to marry the girl, not the legal age. Below we provide some direct quotations on each variety of early marriage to further inform the reader about this practise.

Kossegué as arranged marriage: "They say that in the Sénoufo communities, they practise the Kossegué. What is the Kossegué? It means that when you take a woman into a family, if that woman gives birth to a girl, the girl has to go back to her mother's family to get married. However, our laws do not recogniSe that practise. So, as a result, there is a problem between the law and their culture. Often it is difficult for them to understand. When you tell them that a girl who is not 18 years old is a minor, someone who has not been to school cannot understand that. $\mathrm{He} / \mathrm{she}$ says: "no as soon as you see the girl with breasts, well it's (laughs). So, often it makes it difficult to solve cases" (Male, KII, Koloko, Burkina Faso)

Wanted early marriage: "This a variety of early marriage. The young person meets during the demonstrations in the different villages. The young man and the girl consult each other next door. You'll find that it's a girl engaged by another young man. So, if they have agreed with the girl, he comes to take the girl and then go away with her somewhere else. There is a problem there, because the man who engaged the girl had been working in the fields for his in-laws for three years. You will find that the latter had already done the three years of work for the girl's parents, and someone else is coming to take her to go away. That's the problem "(Male, KII, Koury, Mali)

Kidnapping and abduction: Another variety of forced marriage is the abduction of married women. A woman who is already married and living with her husband can be abducted by another man. This is said to happen regularly within the communities, as explained below.

"The conflicts that are common in our community are land conflicts and women's conflicts; someone can come and take someone else's wife, and this can create problems."

(Male, KII, Koury, Mali)

"Our Social Action department is mostly asked to intervene for cases relating to the abduction of women and girls."

(Male, KII, Faramana, Burkina Faso) 


\section{Conflict resolution mechanisms}

Quantitative respondents were asked who had the most common influence on what is required, permitted, or forbidden in the community. This was done to give an indication of what conflict resolution mechanisms exist in each locality. Appendix Table 1 shows the overall proportion of what respondents cited to be the most influential of these mechanisms. We disaggregate these results by gender.

In Burkina Faso, local government was cited by $39 \%$ of the respondents as having the most influence, while $28 \%$ stated national government, $25 \%$ stated $\%$ stated traditional authorities (i.e. village chiefs, land chief, village elders), and $6 \%$ stated religious authorities. These options were given to them as multiple choice, including an option "other." The rest either did not know or refused to respond to the question. There was a slightly significant difference in how male and female respondents answered this question ( $p=0.038$ ), with $43 \%$ and $30 \%$ of the male respondents, respectively, in Burkina Faso and Mali, citing local and national governments, compared to $34 \%$ (local governments) and $27 \%$ (national governments) of the female respondents. The proportion of female respondents who cited religious authorities (8\%) was also double that of male respondents who cited the same mechanism (4\%). In Mali, a relatively higher proportion of the respondents said traditional authorities (36\%) had more influence, followed by about a third of the respondents citing local governments. National government was a popular conflict resolution mechanism among $24 \%$ of the respondents and $7 \%$ cited religious authorities. The rest of the respondents either did not know or refused to respond to the question. There was no significant association between gender and type of conflict resolution response in Mali.

The qualitative data indicate that there is a clear difference between the two countries. In Mali, traditional leaders, particularly Muslim leaders, opposed the idea of passing an FGM law in the country. Some interviewees openly explained that politicians do not dare to challenge these traditional authorities by enforcing an unwanted law.

Qualitative KIls and FGDs also provided in-depth information on conflict resolution mechanisms. These data suggest that the mechanism chosen (customary or government route) depends on the nature of the conflict, but conciliation is almost always reported to be the outcome. In general, people would use the customary route first and it is ONLY when no solution is found by way of that mechanism that the disputants turn to the government authorities (the prefect, the mayor, the police/gendarmerie, and finally the court). The main conflict resolver in all locations was reported to be the village chief. But he does not judge the case alone; he consults his ministers, the land chief (for land disputes), the Development Committee (in Burkina Faso), and even religious leaders to find a solution. The quotes below help illustrate how conflict resolution occurs at the village level.

\section{Q: How do you solve disputes over women abductions?}

R: "We go to the village chief; we tell the chief and his advisers that this person has taken that person's fiancée. So, the village chief and his counsellors can say: go tell the one who took another person's fiancée to bring the girl back so that she can join her real fiancé. So, when the messenger tells that message to the other party, the kidnapper comes back with the girl to the chief and the chief takes the girl to her parents. The parents in turn will drive the girl to her husband's house. [...] Everything is settled at the level of the village chief."

(Female, KII, Koury, Mali)

Interestingly, even local government representatives often advise disputants to solve their problems first through the customary route, as explained below by a prefect. 
"Generally, we call on communities to engage in grassroots discussions with the village chief, his advisors and notabilities. Each conflict that is related to land or to questions of customs and habits, to the exploitation of natural resources, we ask communities to go back to the village, to take the evil by the root, to exchange with the elders in order to find the solution."

(Male, KII-Security, Boura, Burkina Faso)

When the customary route has failed, people will often turn to the local government (prefect, gendarmerie/police, court) or the mayor. In some rare cases, people go straight to the police or the prefect when they want the other party to be punished or when they want to rely less on customary norms. For example, a man who abducted a girl without her parents' consent might go to the local government. Some extreme disputes are also taken directly to the local government, such as a fight that injured or killed a person. A case is then taken to court if no solution is found by the local government.

\section{Legal knowledge}

\section{Knowledge of legality or illegality of FGM/C practise}

Respondents were also asked to give their opinion whether to the best of their knowledge they thought $\mathrm{FGM} / \mathrm{C}$ was legal and whether they had a legal obligation to comply with the law prohibiting the practice. We then compared this with what they thought about other criminalised activities like cutting wood in the forest or bush and paying a bribe to the police to avoid getting into trouble. Figure 3 shows the results by country, disaggregated by gender within each country.

Figure 3: Proportion of respondents in Burkina Faso and Mali who think FGM/C is legal

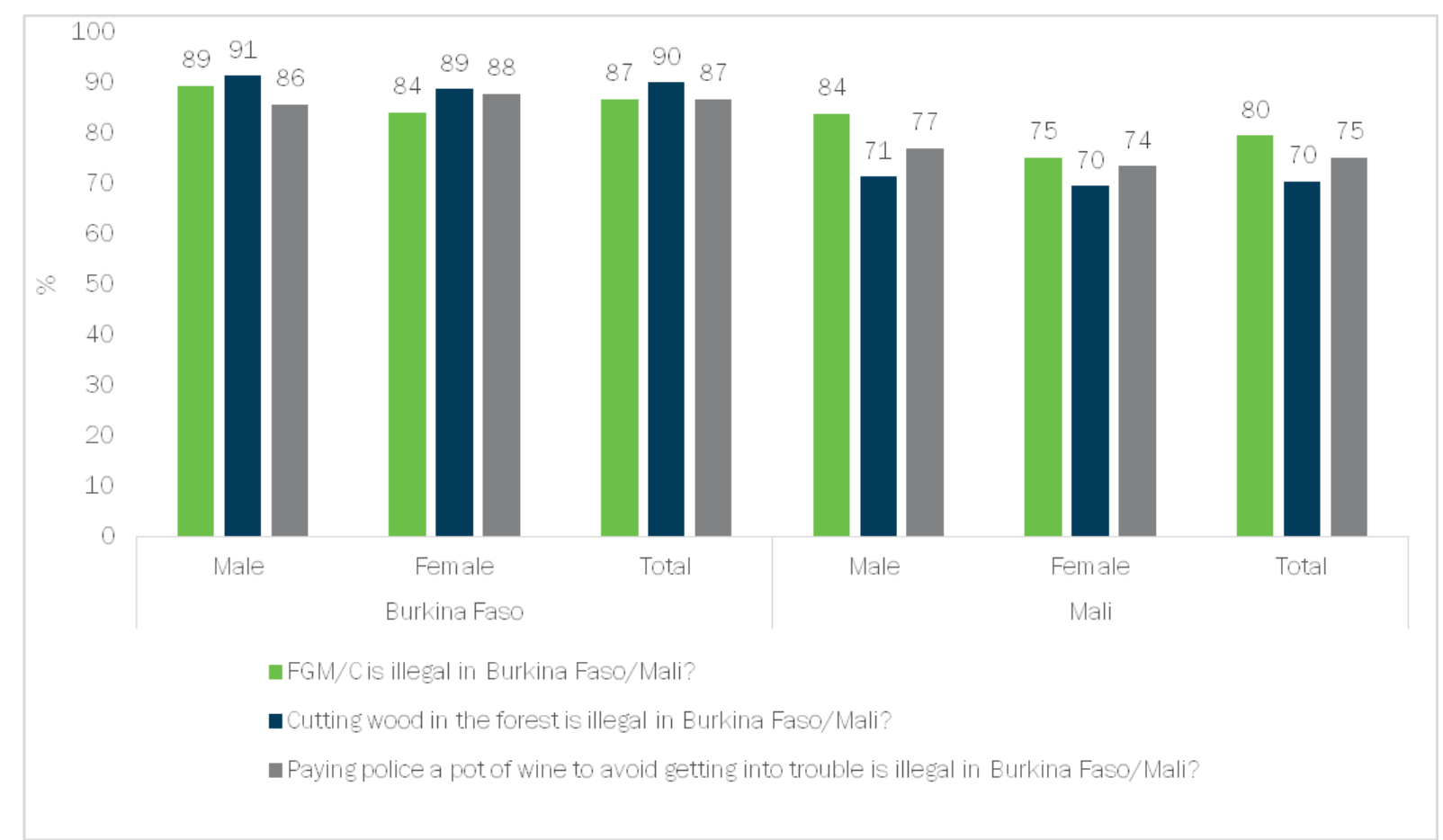

Overall, $87 \%$ of all the respondents in Burkina Faso and $80 \%$ of all the respondents in Mali thought that $\mathrm{FGM} / \mathrm{C}$ was illegal, and $6 \%$ of the respondents from both Burkina Faso and Mali did not know whether FGM/C was illegal or not. While there was no significant difference between male and females in their knowledge of whether FGM/C was legal or illegal in Burkina Faso, there was a significant difference in FGM/C legal knowledge between males and females in Mali ( $p=0.001$ ), with $84 \%$ of males thinking FGM/C was illegal compared to $75 \%$ of females. Table 3 
shows results disaggregated by pair communes. We compared Faramana (BF) and Koury (M), Koloko (BF) and Finkolo (M), and Tansila (BF) and Boura (M). We also looked at how FGM/C legal knowledge compares to legal knowledge related to other activities like cutting wood in the forest and paying police a bribe to avoid getting into trouble.

Table 3 Knowledge of legality or illegality of FGM/C among pair communes in Burkina Faso and Mali

\begin{tabular}{|c|c|c|c|c|c|c|c|}
\hline & $\begin{array}{l}\text { Faramana } \\
(\mathrm{BF})\end{array}$ & $\begin{array}{l}\text { Koury } \\
(\mathrm{M})\end{array}$ & $\begin{array}{l}\text { Koloko } \\
(\mathrm{BF})\end{array}$ & $\begin{array}{l}\text { Finkolo } \\
(\mathrm{M})\end{array}$ & $\begin{array}{l}\text { Tansila } \\
\text { (BF) }\end{array}$ & $\begin{array}{l}\text { Boura } \\
\text { (M) }\end{array}$ & Total \\
\hline \multicolumn{8}{|c|}{ Is FGM/C legal in Burkina Faso/Mali? } \\
\hline Yes & $14(6.9)$ & $29(14.4)$ & $17(8.5)$ & $35(17.4)$ & $14(7)$ & $25(12.3)$ & $134(11.1)$ \\
\hline No & $166(81.8)$ & $148(73.3)$ & $179(89.5)$ & $163(81.1)$ & $178(89.0)$ & $171(84.2)$ & $1005(83.1)$ \\
\hline Don't know & $23(11.3)$ & $25(12.4)$ & $4(2.0)$ & $3(1.5)$ & $8(4.0)$ & $7(3.5)$ & $70(5.8)$ \\
\hline \multicolumn{8}{|c|}{ Is cutting wood in the forest legal in Burkina Faso/Mali? } \\
\hline Yes & $20(9.9)$ & $52(25.7)$ & $6(3.0)$ & $58(28.9)$ & $16(8.0)$ & $36(17.7)$ & $188(15.6)$ \\
\hline No & $171(84.2)$ & $125(61.9)$ & $193(96.5)$ & $137(68.2)$ & $179(89.5)$ & $165(81.3)$ & $970(80.2)$ \\
\hline Don't know & $12(5.9)$ & $24(11.9)$ & $1(0.5)$ & $5(2.5)$ & $5(2.5)$ & $2(1.0)$ & $49(4.1)$ \\
\hline $\begin{array}{l}\text { Refused to } \\
\text { answer }\end{array}$ & $0(0.0)$ & $1(0.5)$ & $0(0.0)$ & $1(0.5)$ & $0(0.0)$ & $0(0.0)$ & $2(0.2)$ \\
\hline \multicolumn{8}{|c|}{ Is paying police a bribe to avoid getting to trouble legal in Burkina Faso/Mali? } \\
\hline Yes & $34(16.8)$ & $37(18.3)$ & $17(8.5)$ & $54(26.9)$ & $13(6.5)$ & $27(13.3)$ & $182(15.1)$ \\
\hline No & $156(76.9)$ & $138(68.3)$ & $182(91.0)$ & $146(72.6)$ & $185(92.5)$ & $172(84.7)$ & $979(81.0)$ \\
\hline Don't know & $10(4.9)$ & $27(13.4)$ & $1(0.5)$ & $1(0.5)$ & $2(1.0)$ & $4(2.0)$ & $45(3.7)$ \\
\hline $\begin{array}{l}\text { Refused to } \\
\text { answer }\end{array}$ & $3(1.5)$ & $0(0.0)$ & $0(0.0)$ & $0(0.0)$ & $0(0.0)$ & $0(0.0)$ & $3(0.3)$ \\
\hline
\end{tabular}

The results in Table 3 above indicate that a relatively higher proportion of participants from Burkina Faso-Faramana (82\%), Koloko (90\%), and Tansila (89\%)-reporting that FGM/C was illegal compared to those from Mali-Koury (73\%), Finkolo (81\%), and Boura (83\%), respectively. We also found that $11 \%$ and $12 \%$ of the respondents in Faramana and Koury respectively did not know whether FGM/C was legal or not. Commune variation does exist in the sample. In Tansila, $87 \%$ of the male respondents and $91 \%$ of the female respondents knew FGM/C was illegal. Apart from Tansila, a relatively higher proportion of male respondents knew FGM/C was illegal compared to females. It bears mentioning here that the figures on the Mali side are particularly noteworthy, given that FGM/C is NOT illegal in Mali. In other words, legal knowledge in surveyed towns in Mali is strikingly inaccurate, but in a way that may reduce the practice of $\mathrm{FGM} / \mathrm{C}$.

We also note respondents' legal knowledge with respect to subjects other than FGM/C. The proportion of those who did not know whether an activity was illegal in Faramana was considerably lower in terms of knowledge of the legality of cutting wood in the forest $(6 \%)$ and paying police a bribe (5\%). A similar pattern (not knowing if an activity is legal or not) was noted in Koloko ( $2 \% \mathrm{FGM} / \mathrm{C})$, with $1 \%$ not knowing whether cutting wood in the forest was illegal and $1 \%$ not knowing whether paying the police a bribe was illegal; in Tansila, these numbers were with $4 \%$ for $\mathrm{FGM} / \mathrm{C}, 3 \%$ for cutting wood in the forest, and $1 \%$ for paying the police a bribe. Compared to their FGM/C responses, relatively lower proportions of participants from communes in Mali (Koury, Finkolo, Boura) reported other activities, like cutting wood in the forest and paying 
police a bribe, to be illegal. Appendix Table 2 shows the results disaggregated by gender and commune.

The fact that a high proportion of people in Burkina Faso know that FGM/C is illegal (Faramana $82 \%$, Koloko $90 \%$, and Tansila $89 \%$ ) confirms the findings of previous studies (Ramey et al. 2019; CNLPE 2016; UNFPA 2016). This strong knowledge was also persistent among FGD participants, who were well aware that FGM/C is illegal in Burkina Faso and stated that this is one of the reasons why they no longer cut girls.

The Mali results on legal knowledge showed Koury (73\%), Finkolo (81\%), and Boura (83\%) believing that FGM/C is illegal. As mentioned briefly above, there is no law banning $F G M / C$ in Mali. We need to dive deeper through further research to explain why respondents in Mali are so wrong (in a good way) about FGM/C law in their own country. We need to test the hypotheses related to possible cross-border effects of the $\mathrm{FGM} / \mathrm{C}$ campaigns that have taken place in Burkina Faso; it is possible cross-border diffusion of ideas and knowledge explains the surprising Mali results. It is also possible that sensitisation campaigns undertaken by anti-FGM/C NGOs in Mali may have affected legal knowledge. Regardless, future research should investigate any and all factors that led people in the surveyed villages in Mali to believe that FGM/C is illegal. This is particularly true given that our qualitative data indicate that even some local government representatives in Mali think that FGM/C is illegal in their own country. The below three qualitative excerpts should help illustrate some of the legal knowledge complexities we found on the ground.

"Now I would like to know if there is a law against FGM/C in Mali?

Yes, there is a law prohibiting FGM/C in Mali, as I said, there was a decision.

Is it the same as in Burkina Faso?

Well, I cannot say because I haven't read the content of the laws of two countries; I don't know their details, but I think that these countries have about the same views on decision-making against $F G M / C$, the content of the laws can vary slightly but the main goal of these laws is for women to thrive.

One last question, when did the law against FGM/C in Mali come into effect?

It is in 2003, if I am not mistaken. The measure has been taken and it was said on TV and radio by doctors that girls should not undergo excision."

Male, KII, Koury, Mali

"This law states that any person who is caught in the process of carrying out this practise will be punished, and this sanction may result in the payment of a fine in the sense that the practise leads to unfortunate complications on the girl's body."

Female, FGD 35+, Finnkolo, Mali

"As I said, in Mali, it seems that the law is not enforced; many people are afraid to do it officially [the cutting], they really do it underground. They don't do it openly."

Male, KII, Finnkolo, Mali

To further complicate this picture, some participants in Mali said that they do not know whether or not an FGM/C law exists in Mali, but that they do not respect the sensitisation messages they hear on the radio. Below are the arguments used by 18-34-year-old FGD participants to justify why this is so.

$\mathrm{Q}$ : You heard on the radio that $\mathrm{FGM} / \mathrm{C}$ is not good, but do people here respect that? 
No. 6: "No, people don't respect it."

No. 1: "We listen to the radio, but we do not respect it because those who even say not to do it, hide to cut their own daughters. They think we are bushmen, which is why we also cut our daughters [laughers]. On the radio, they said that it is bad, yet those who say it do it underground."

No. 3: "No, but deciding not to cut a girl is bad in the sense that boys will consider her as "blakolo" [a pejorative expression in Dioula which means an impure person] and will laugh while saying that she will have difficulty finding a husband; this is why it is difficult for us to respect the law."

Females, FGD 18-34, Koury, Mali

\section{Source of information about statutory and customary law}

Table 4 below shows the main sources of information on statutory law, as well as for customary law and associated practises. The results are disaggregated by country and by gender within each country.

Table 4: Main sources of information for statutory law and customary law

\begin{tabular}{|c|c|c|c|c|c|c|c|}
\hline & \multicolumn{3}{|c|}{ Burkina Faso } & \multicolumn{3}{|c|}{ Mali } & \multirow[b]{2}{*}{$\begin{array}{l}\text { Total } \\
(\mathrm{N}=1209)\end{array}$} \\
\hline & $\begin{array}{l}\text { Male } \\
(\mathrm{N}=301)\end{array}$ & $\begin{array}{l}\text { Female } \\
(\mathrm{N}=302)\end{array}$ & $\begin{array}{l}\text { Total } \\
(\mathrm{N}=603)\end{array}$ & $\begin{array}{l}\text { Male } \\
(\mathrm{N}=304)\end{array}$ & $\begin{array}{l}\text { Female } \\
(\mathrm{N}=302)\end{array}$ & $\begin{array}{l}\text { Total } \\
(\mathrm{N}=606)\end{array}$ & \\
\hline \multicolumn{8}{|c|}{ Sources of information about statutory law } \\
\hline Radio & $136(45.2)$ & $118(39.1)$ & $254(42.1)$ & $187(61.5)^{*}$ & $156(51.7)$ & $343(56.6) \ddagger$ & $597(49.4)$ \\
\hline Television & $65(21.6)$ & $59(19.5)$ & $124(20.6)$ & $58(19.1)$ & $53(17.5)$ & $111(18.3)$ & $235(19.4)$ \\
\hline Newspaper/magazines & $5(1.7) *$ & $0(0.0)$ & $5(0.8)$ & $3(1.0)$ & $1(0.3)$ & $4(0.7)$ & $9(0.7)$ \\
\hline Family/fiends & $45(15.0)$ & $83(27.5)^{* *}$ & $128(21.2) \ddagger$ & $18(5.9)$ & $50(16.6)^{* *}$ & $68(11.2)$ & $196(16.2)$ \\
\hline Observation & $13(4.3)$ & $12(4.0)$ & $25(4.1)$ & $6(2.0)$ & $11(3.6)$ & $17(2.8)$ & $42(3.5)$ \\
\hline Elected officials & $22(7.3)$ & $14(4.6)$ & $36(6.0)$ & $17(5.6)$ & $18(6.0)$ & $35(5.8)$ & $71(5.9)$ \\
\hline Traditional authorities & $1(0.3)$ & $5(1.7)$ & $6(1.0)$ & $8(2.6)$ & $4(1.3)$ & $12(2.0)$ & $18(1.5)$ \\
\hline Religious authorities & $2(0.7)$ & $1(0.3)$ & $3(0.5)$ & $1(0.3)$ & $0(0.0)$ & $1(0.2)$ & $4(0.3)$ \\
\hline Police/gendarmerie & $0(0.0)$ & $0(0.0)$ & $0(0.0)$ & $1(0.3)$ & $1(0.3)$ & $2(0.3)$ & $2(0.2)$ \\
\hline Other & $11(3.7)$ & $8(2.6)$ & $19(3.2)$ & $5(1.6)$ & $5(1.7)$ & $10(1.7)$ & $29(2.4)$ \\
\hline Don't know & $1(0.3)$ & $2(0.7)$ & $3(0.5)$ & $0(0.0)$ & $3(1.0)$ & $3(0.5)$ & $6(0.5)$ \\
\hline \multicolumn{8}{|c|}{ Sources of information about customary law and practises } \\
\hline Radio & $5(1.7)$ & $8(2.6)$ & $13(2.2)$ & $21(6.9)$ & $26(8.6)$ & $47(7.8) \ddagger$ & $60(5.0)$ \\
\hline Television & $6(2.0)$ & $3(1.0)$ & $9(1.5)$ & $1(0.3)$ & $3(1.0)$ & $4(0.7)$ & $13(1.1)$ \\
\hline Newspaper/magazines & $1(0.3)$ & $1(0.3)$ & $2(0.3)$ & $1(0.3)$ & $0(0.0)$ & $1(0.2)$ & $3(0.3)$ \\
\hline Family/friends & $112(37.2)$ & $134(44.4)$ & $246(40.8)$ & $96(31.6)$ & $123(40.7) *$ & $219(36.1)$ & $465(38.5)$ \\
\hline Observation & $37(12.3)$ & $50(16.6)$ & $87(14.4)$ & $39(12.8)$ & 39 (12.9) & 78 (12.9) & $165(13.7)$ \\
\hline Elected officials & $12(4.0)$ & $10(3.3)$ & $22(3.6)$ & $12(3.9)$ & $9(3.0)$ & $21(3.5)$ & $43(3.6)$ \\
\hline Traditional authorities & $116(38.5) * *$ & $86(28.5)$ & $202(33.5)$ & $114(37.5)$ * & $86(28.5)$ & $200(33.0)$ & $402(33.3)$ \\
\hline Religious authorities & $3(1.0)$ & $2(0.7)$ & $5(0.8)$ & $18(5.9)$ & $12(4.0)$ & $30(5.0) \ddagger$ & $35(2.9)$ \\
\hline Police/gendarmerie & $0(0.0)$ & $0(0.0)$ & $0(0.0)$ & $0(0.0)$ & $0(0.0)$ & $0(0.0)$ & $0(0.0)$ \\
\hline Other & $7(2.3)$ & $6(2.0)$ & $13(2.2)$ & $1(0.3)$ & $1(0.3)$ & $2(0.3)$ & $15(1.2)$ \\
\hline
\end{tabular}




\begin{tabular}{|c|c|c|c|c|c|c|c|}
\hline \multirow[b]{3}{*}{ Don't know } & \multicolumn{3}{|c|}{ Burkina Faso } & \multicolumn{3}{|c|}{ Mali } & \multirow[b]{2}{*}{$\begin{array}{l}\text { Total } \\
(\mathrm{N}=1209)\end{array}$} \\
\hline & $\begin{array}{l}\text { Male } \\
(\mathrm{N}=301)\end{array}$ & $\begin{array}{l}\text { Female } \\
(\mathrm{N}=302)\end{array}$ & $\begin{array}{l}\text { Total } \\
(\mathrm{N}=603)\end{array}$ & $\begin{array}{l}\text { Male } \\
(\mathrm{N}=304)\end{array}$ & $\begin{array}{l}\text { Female } \\
(\mathrm{N}=302)\end{array}$ & $\begin{array}{l}\text { Total } \\
(\mathrm{N}=606)\end{array}$ & \\
\hline & $2(0.7)$ & $2(0.7)$ & $4(0.7)$ & $0(0.0)$ & $3(1.0)$ & $3(0.5)$ & $7(0.6)$ \\
\hline Refused to answer & $0(0.0)$ & $0(0.0)$ & $0(0.0)$ & $1(0.3)$ & $0(0.0)$ & $1(0.2)$ & $1(0.1)$ \\
\hline
\end{tabular}

Radio was the main source of information regarding statutory law, as reported by about half of all respondents. About one-fifth and $16 \%$, respectively, said that television and family/friends/ community were their main sources of information regarding statutory law. There were significant differences by country $(p<0.001)$ and by gender in both Burkina Faso $(p=0.005)$ and Mali $(p=0.004)$, in terms of what respondents believe to be their main source of information on statutory law. Forty-five percent of male respondents and $39 \%$ of the female respondents in Burkina Faso thought that the radio was the main source, with $15 \%$ of male respondents and $28 \%$ of female respondents thinking family was the main source. In Mali, $62 \%$ of male respondents and $52 \%$ of female respondents thought radio was the main source of information regarding statutory law. Notably, as compared to the $6 \%$ of the male respondents who thought family or friends were their main source of information regarding statutory law, $17 \%$ of female respondents believed the same.

Meanwhile, in terms of sources of information regarding customary law, a third of all respondents believed this to be traditional authorities, $39 \%$ thought it was family or friends, and $14 \%$ believed observation to be their primary source of information. There were significant differences by country $(p<0.001)$, but we did not observe significant differences by gender in either Burkina Faso $(p=0.310)$ or Mali $(p=0.118)$. Forty-one percent of respondents from Burkina Faso, as compared to $36 \%$ of respondents from Mali, stated that family or friends were their main source of information regarding customary law and associated practises, while $34 \%$ of respondents from Burkina Faso, as compared to $29 \%$ of respondents from Mali thought it was traditional authorities. Notably, less than $1 \%$ of respondents from Burkina Faso thought religious authorities were the main source, as compared to $6 \%$ in Mali. Appendix Table 3 details the main sources of information regarding statutory law and customary law and practises by pair communes and by gender within each commune.

Key informants and FGD participants largely confirmed the diverse sources of information on customary law found in the quantitative data. Radio was their main source, in addition to family/friends/community, traditional leaders (the village chief; the Village Development Committee [CVD] in Burkina Faso; the Land Committee [COFO] in Mali), community meetings with the local government (the health workers, mayors, prefects), NGOs, and education at schools. It is important to note that many have received quite a lot of information on the health consequences of $\mathrm{FGM} / \mathrm{C}$ through local health workers. Also of note is the fact that, while customary law is a written law, the majority of the people in the study sites are illiterate and, thus, their knowledge of it is mediated by others. The local radio station, which includes broadcasts in the local language, is the most accessible media used by government officials, NGOs, judges, and anyone who wants their message to reach the maximum number of people. Finally, in some cases, people learn about the law when they have to deal with the authorities, so they learn by experience. The qualitative data below are meant to illustrate some of the key findings.

How have you learned that $\mathrm{FGM} / \mathrm{C}$ is illegal? 
"I learned from the health workers who told us not to do it anymore because the law bans cutting the girls."

Female, FGD 35+, Faramana, Burkina Faso

"To be aware of government laws, for example the court, the local Departmental Court [the prefecture] often makes publications called bench publications and those who are educated read them and when the illiterate person asks, they are explained to them."

Male, KII, Faramana, Burkina Faso

"There are radio broadcasts where the judge even comes to explain certain provisions of the law to the public. Here in Mali, when people have problems, they go directly to the traditional chief or to the mayors, who are supposed to explain the laws to the population because the population does not come directly to us to learn about the law or for guidance. It is when they come to us for specific problems that we explain the law to them. However, it is difficult, especially for people who have never been to school, it is not easy to make them understand and accept the law. Often, for these people we even take the Penal Code and read them the provision of the law that applies to the offence in question and everything related to it."

Male, KII, Koury, Mali

\section{Legal obligation to comply with the law}

We also sought to determine whether respondents believed that people had any legal obligation to comply with the law prohibiting FGM/C. Figure 4 shows the proportion of respondents who thought they had a legal obligation to comply with FGM/C law in both Burkina Faso and Mali, disaggregating by gender within each country.

Figure 4: Proportion of respondents who reported having a legal obligation to comply with the law, in Burkina Faso and Mali

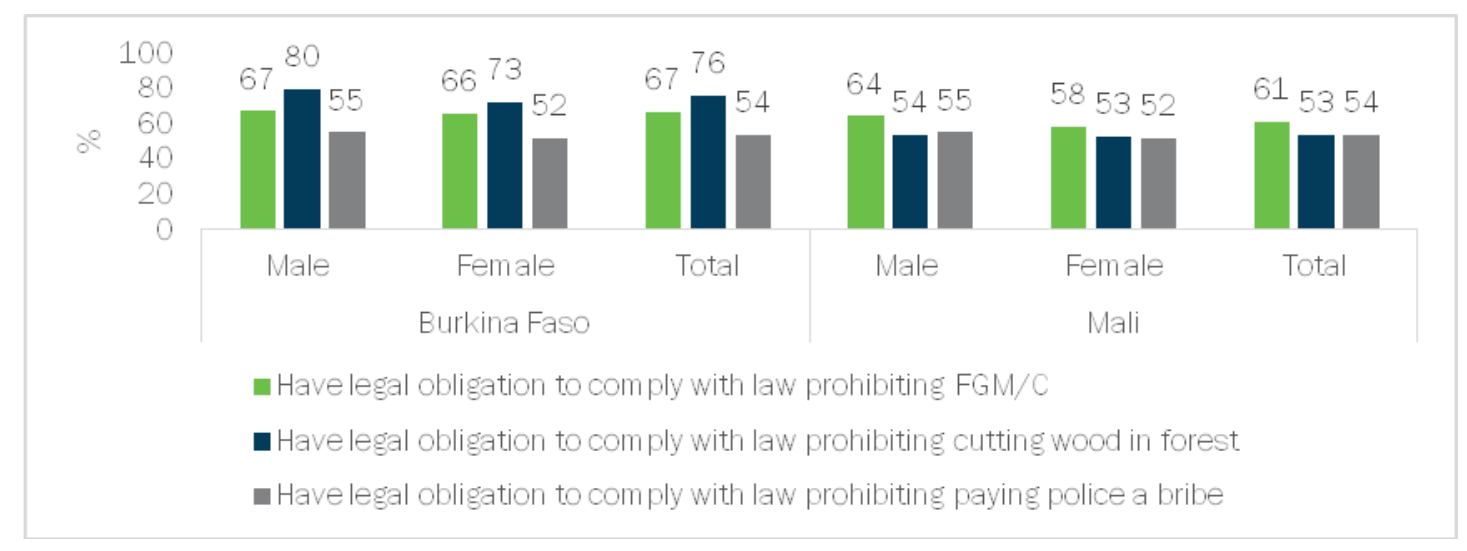

Overall, $64 \%$ of all the respondents in both countries thought people had an obligation to comply with a law prohibiting $\mathrm{FGM} / \mathrm{C}$, while $33 \%$ said they did not have any legal obligation to do that, and $3 \%$ did not know. Overall, $67 \%$ and $61 \%$ of respondents from Burkina Faso and Mali, respectively, were of the opinion that people had a legal obligation. There were significant differences by gender in both countries with $5 \%$ and $6 \%$ of female respondents in Burkina Faso $(p=0.025)$ and Mali $(p=0.004)$, respectively, not knowing whether they had a legal obligation, as compared to $1 \%$ of their male counterparts saying the same.

\section{Legal punishment}


Respondents were asked if they knew anyone who had been punished or penalised for practising $\mathrm{FGM} / \mathrm{C}$, for cutting wood in the forest, or for paying police a bribe in order to avoid getting into trouble. They were also asked what type of punishment they thought they would receive for a violation. Table 5 shows the overall results of whether respondents knew anyone who had been punished, while Figure 5 shows the type of punishment respondents thought they would receive for violating each law.

Table 5: Proportions of who had been punished for practising FGM/C or cutting wood in the forest or paying police a bribe

\begin{tabular}{|c|c|c|c|c|c|c|c|}
\hline & \multicolumn{3}{|c|}{ Burkina Faso (B) } & \multicolumn{3}{|l|}{ Mali (M) } & \multirow{2}{*}{$\begin{array}{l}\text { Total }_{\mathrm{B}+\mathrm{M}} \\
(\mathrm{N}=1209)\end{array}$} \\
\hline & $\begin{array}{l}\text { Female } \\
(\mathrm{N}=302)\end{array}$ & $\begin{array}{l}\text { Male } \\
(\mathrm{N}=301)\end{array}$ & $\begin{array}{l}\text { Total }_{\mathrm{BF}} \\
(\mathrm{N}=603)\end{array}$ & $\begin{array}{l}\text { Female } \\
(\mathrm{N}=302)\end{array}$ & $\begin{array}{l}\text { Male } \\
(\mathrm{N}=304)\end{array}$ & $\begin{array}{l}\text { Total }_{M} \\
(\mathrm{~N}=606)\end{array}$ & \\
\hline \multicolumn{8}{|c|}{ Has anyone you know been penalised for practising FGM/C } \\
\hline Yes & $49(16.2)$ & $68(22.6)$ & $117(19.4)$ & $63(20.9)$ & $74(24.3)$ & $137(22.6)$ & $254(21.0)$ \\
\hline No & $244(80.8)$ & $228(75.8)$ & $472(78.3)$ & $228(75.5)$ & $225(74.0)$ & $453(74.8)$ & $925(76.5)$ \\
\hline Don't know & $9(3.0)$ & $5(1.7)$ & $14(2.3)$ & $10(3.3)$ & $5(1.6)$ & $15(2.5)$ & $29(2.4)$ \\
\hline Refused to answer & $0(0.0)$ & $0(0.0)$ & $0(0.0)$ & $1(0.3)$ & $0(0.0)$ & $1(0.2)$ & $1(0.1)$ \\
\hline \multicolumn{8}{|c|}{ Has anyone you know been penalised for cutting wood in the forest/bush? } \\
\hline Yes & $65(25.5)$ & $73(24.3)$ & 138 (24.9?) & $42(13.9)$ & $55(18.1)$ & $97(16.0)$ & $235(19.4)$ \\
\hline No & $231(76.5)$ & $225(74.8)$ & $456(75.6)$ & $254(84.1)$ & $242(79.6)$ & 496 (81.9) & $952(78.7)$ \\
\hline Don't know & $5(1.7)$ & $3(1.0)$ & $8(1.3)$ & $5(1.7)$ & $7(2.3)$ & $12(2.0)$ & $20(1.7)$ \\
\hline Refused to answer & $1(0.3)$ & $0(0.0)$ & $1(0.2)$ & $1(0.3)$ & $0(0.0)$ & $1(0.2)$ & $2(0.2)$ \\
\hline \multicolumn{8}{|c|}{ Has anyone you know been penalised for paying police a bribe to avoid getting into trouble? } \\
\hline Yes & $98(32.5)$ & $120(39.9)$ & $218(36.2)$ & $90(29.8)$ & $125(41.1)$ & $215(35.5)$ & $433(35.8)$ \\
\hline No & $202(66.9)$ & $179(59.5)$ & $381(68.2)$ & $209(69.2)$ & $175(57.6)$ & $384(63.4)$ & $765(63.3)$ \\
\hline Don't know & $2(0.7)$ & $2(0.7)$ & $4(0.7)$ & $2(0.7)$ & $4(1.3)$ & $6(1.0)$ & $10(0.8)$ \\
\hline Refused to answer & $0(0.0)$ & $0(0.0)$ & $0(0.0)$ & $1(0.3)$ & $0(0.0)$ & $1(0.2)$ & $1(0.1)$ \\
\hline
\end{tabular}

Overall, $21 \%$ of respondents knew someone who had been punished for practising FGM/C, 19\% knew of someone who had been punished for cutting wood in the forest, and $36 \%$ knew of someone who had been punished for paying police a bribe. There were no significant differences in the proportion of those who knew someone who had been punished for practising FGM/C by country $(p=0.393)$ or by gender, in both Burkina Faso $(p=0.092)$ and in Mali $(p=0.313)$. There were also no significant differences by gender at the commune level.

Figure 5 below presents the types of punishment respondents believe are associated with practising $\mathrm{FGM} / \mathrm{C}$. Respondents in both countries answered that the first sanction is paying a fine (28.2\% in Mali and $25.4 \%$ in Burkina Faso) followed by imprisonment in Burkina Faso and no sanction in Mali. 
Figure 5: Respondents' opinions on types of punishment that they believe are associated with FGM/C in Burkina Faso and Mali

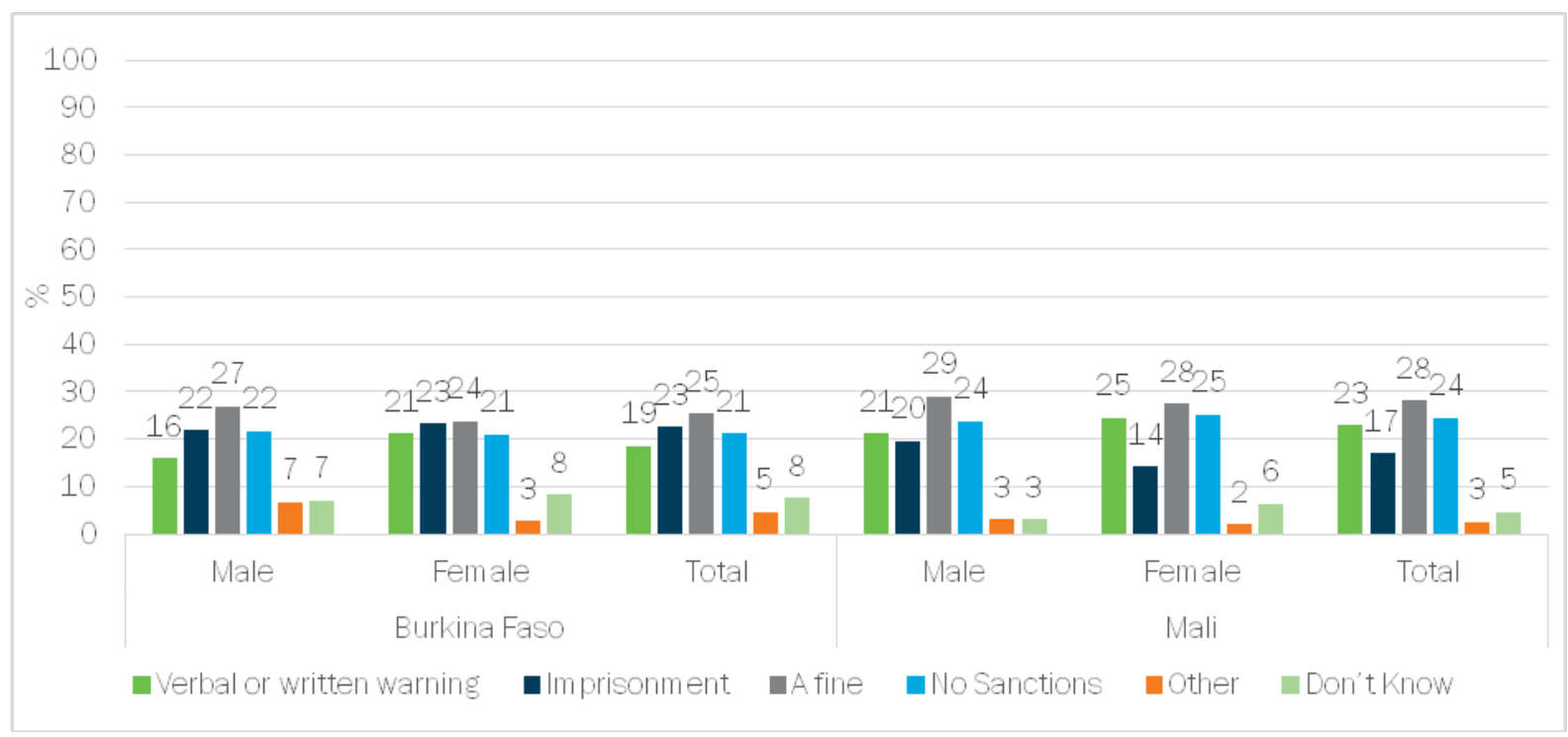

In addition, Appendix Table 4 details the proportion of respondents who had been punished for practising FGM/C and the nature of the punishment. These data are disaggregated by pair commune and by gender within each commune.

It should once again be noted that the Mali results described above are surprising. This is because there is no law against FGM/C in Mali. Despite this, $22.6 \%$ of respondents said they knew someone who had been punished for practising $F G M / C$ (compared to $19.4 \%$ of respondents in Burkina Faso). We need to understand the specific actions for which these people were punished. The below response from a key informant who is a representative of a local court in Mali provides some insight into how FMG/C may be indirectly covered by other laws in Mali.

"Now let's assume that a family is considering cutting their daughter, is this allowed?

You know that the Malian law implicitly says that FGM/C is prohibited, I say 'implicitly' [...]. So implicitly, if we want to make what is called an interpretation of the law, it is clear that this practise is prohibited by the Malian law. Now, has the word FGM (female genital mutilation) or the word excision reached the level of political courage to say it openly? No! You know that generally FGM is practised, generally it is barely accepted [...] there is no FGM/C problem brought to us, but the problems arise when the health of the girl is concerning as a result of this practise. If there is a case of death or disability, the parents now go to the authorities and there the magistrates, the judges; have the right words to qualify the facts. Maybe they will use assault and battery, or at least they will use the right words, but they will not say genital mutilation or excision, they will find the right words to repress all the parties involved in this practise. [...] Until now you will not see the words excision and female genital mutilation anywhere in the Penal Code, neither in the Persons and Family Code nor in the Malian Constitution."

Male, KII, Koury, Mali

We also sought to determine which actors were punishable by law according to respondents and who they believed was responsible for enforcement of FGM/C law in Burkina Faso and Mali. This section also examines what respondents thought would happen to a person, in terms of punishment if he/she were to practise FGM/C. Figure 6 shows the proportion of people respondents believed to be punishable for practising $\mathrm{FGM} / \mathrm{C}$. 


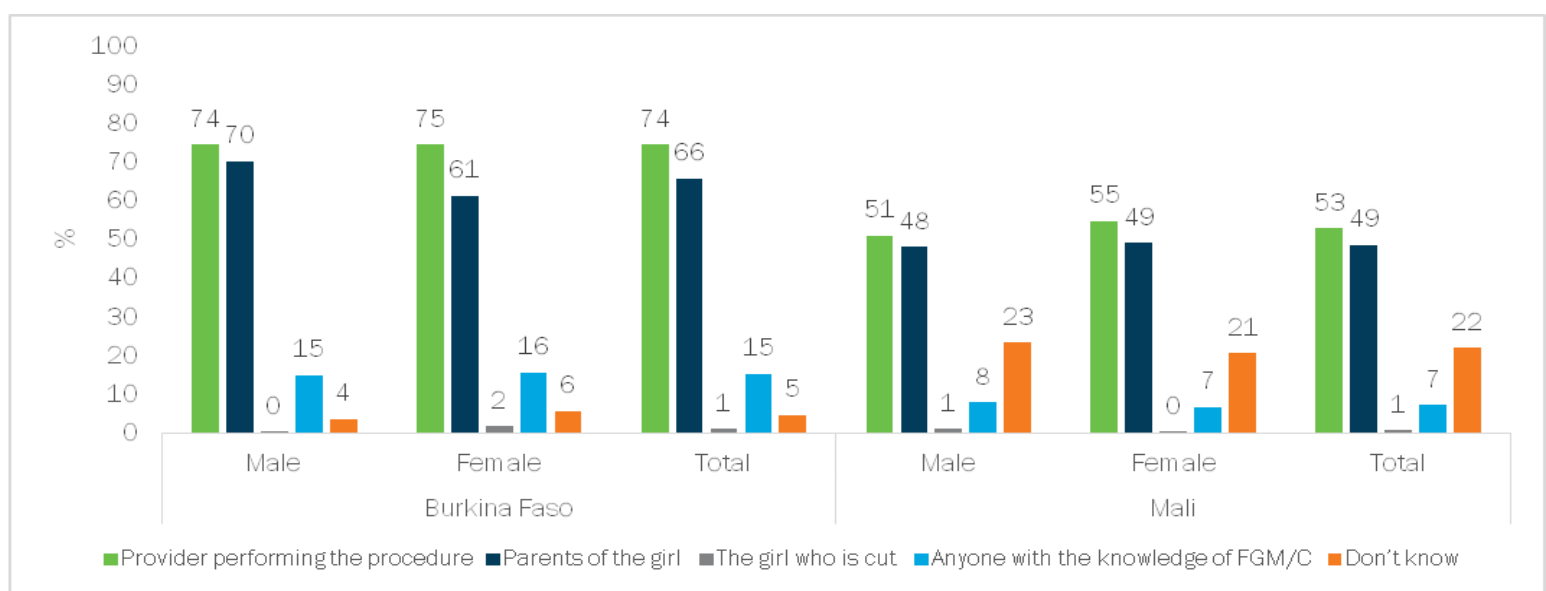

In both Burkina Faso and Mali, a relatively higher majority of respondents believe that the provider who performs the procedure (74\% Burkina Faso, 53\% Mali) and the parents of the girl (66\% Burkina Faso, 49\% Mali) are punishable under the law. There was a significant difference between the proportion of male $(70 \%)$ and female $(61 \%)$ respondents in Burkina Faso who thought the parents of the girl were the ones who would be punished for practising $\mathrm{FGM} / \mathrm{C}$ $(p=0.022)$. The proportion of respondents who did not know who was to be punished for FGM/C violations was significantly higher in Mali (22\%) than in Burkina Faso (5\%) and proportions of those who thought anyone with knowledge of FGM/C could be punished was higher in Burkina Faso (15\%) than in Mali $(7 \%)$. Details related to perceptions of who should be punished for FGM/C violations by pair commune are presented in Appendix Table 4.

The quantitative data described above are generally consistent with the qualitative results. Most key informants and FGD participants said that the person most likely to be punished for FGM/C was the provider who performed the cutting and the parents who brought their daughter to the provider.

"Well, the culprits are the parents first, the parents, mom and dad, because the child belongs to them. They are the ones who brought their daughter to this practise in any case, they are the ones who are in any case the decision-makers, the child is not responsible."

Male, KII, Koury, Mali

Who will be punished?

"According to the law, I personally think that there's the family, it's the family that initiated, it's the family that took the initiative to go and cut the girl, it's the family!"

Male, KII, Faramana, Burkina Faso

"I think everyone should be considered guilty. The person who brought her/his daughter to perform FGM/C must be condemned as well as the cutter."

Male, FGD, Faramana, Burkina Faso

Moving beyond perceptions of who is punishable for $\mathrm{FGM} / \mathrm{C}$ violations, Table 6 , below, shows which actors respondents believe to be responsible for enforcing FGM/C law, as well as other criminalised activities like cutting wood in the forest/bush and paying police bribes to avoid getting into trouble. 
Table 6: Respondents' perceptions on who enforces the law, by country and by gender

\begin{tabular}{|c|c|c|c|c|c|c|c|}
\hline & \multicolumn{3}{|c|}{ Burkina Faso (B) } & \multicolumn{3}{|l|}{ Mali (M) } & \multirow{2}{*}{$\begin{array}{l}\text { Total }_{\mathrm{B}+\mathrm{M}} \\
(\mathrm{N}=1209 \\
)\end{array}$} \\
\hline & $\begin{array}{l}\text { Male } \\
(\mathrm{N}=301)\end{array}$ & $\begin{array}{l}\text { Female } \\
(\mathrm{N}=302)\end{array}$ & $\begin{array}{l}\text { TotalB } \\
(\mathrm{N}=603)\end{array}$ & $\begin{array}{l}\text { Male } \\
(\mathrm{N}=304)\end{array}$ & $\begin{array}{l}\text { Female } \\
(\mathrm{N}=302)\end{array}$ & $\begin{array}{l}\text { Totalm } \\
(\mathrm{N}=606)\end{array}$ & \\
\hline \multicolumn{8}{|c|}{ Who enforces the law against FGM/C? } \\
\hline Police/gendarmerie & $\begin{array}{r}181 \\
(60.1)\end{array}$ & $\begin{array}{r}207 \\
(68.5)\end{array}$ & $\begin{array}{r}388 \\
(64.3)\end{array}$ & $\begin{array}{r}192 \\
(63.2)\end{array}$ & $199(65.9)$ & $391(64.5)$ & $\begin{array}{r}779 \\
(64.4)\end{array}$ \\
\hline Courts & $\begin{array}{r}39 \\
(13.0)\end{array}$ & $26(8.6)$ & $\begin{array}{r}65 \\
(10.8)\end{array}$ & $\begin{array}{r}36 \\
(11.8)\end{array}$ & $17(5.6)$ & $53(8.7)$ & $118(9.8)$ \\
\hline Social Action & $21(7.0)$ & $13(4.3)$ & $34(5.6)$ & $12(3.9)$ & $13(4.3)$ & $25(4.1)$ & $59(4.9)$ \\
\hline Someone else & $24(8.0)$ & $14(4.6)$ & $38(6.3)$ & $\begin{array}{r}35 \\
(11.5)\end{array}$ & $31(10.3)$ & $66(10.9)$ & $104(8.6)$ \\
\hline Don't know & $\begin{array}{r}35 \\
(11.6)\end{array}$ & $\begin{array}{r}42 \\
(13.9)\end{array}$ & $\begin{array}{r}77 \\
(12.8)\end{array}$ & $29(9.5)$ & $41(13.6)$ & $70(11.6)$ & $\begin{array}{r}147 \\
(12.2)\end{array}$ \\
\hline Refused to answer & $1(0.3)$ & $0(0.0)$ & $1(0.2)$ & $0(0.0)$ & $1(0.3)$ & $1(0.2)$ & $2(0.2)$ \\
\hline \multicolumn{8}{|c|}{ Who enforces the law against cutting wood in the forest/bush? } \\
\hline Police/gendarmerie & $\begin{array}{r}198 \\
(65.8)\end{array}$ & $\begin{array}{r}227 \\
(75.2)^{*}\end{array}$ & $\begin{array}{r}425 \\
(70.5)\end{array}$ & $\begin{array}{r}177 \\
(58.2)\end{array}$ & $184(60.9)$ & $361(59.6)$ & $\begin{array}{r}778 \\
(65.0)\end{array}$ \\
\hline Courts & $18(6.0)$ & $18(6.0)$ & $36(6.0)$ & $19(6.3)$ & $8(2.6)$ & $27(4.5)$ & $63(5.2)$ \\
\hline Social Action & $\begin{array}{r}46 \\
(15.3)\end{array}$ & $23(7.6)^{*}$ & $\begin{array}{r}69 \\
(11.4)\end{array}$ & $18(5.9)$ & $15(5.0)$ & $33(5.4)$ & $102(8.4)$ \\
\hline Someone else & $17(5.6)$ & $15(5.0)$ & $32(5.3)$ & $\begin{array}{r}44 \\
(14.5)\end{array}$ & $39(12.9)$ & $83(13.7)$ & $115(9.5)$ \\
\hline Don't know & $22(7.3)$ & $19(6.3)$ & $41(6.8)$ & $\begin{array}{r}46 \\
(15.1)\end{array}$ & $55(18.2)$ & $101(16.7)$ & $\begin{array}{r}142 \\
(11.8)\end{array}$ \\
\hline Refused to answer & $0(0.0)$ & $0(0.0)$ & $0(0.0)$ & $0(0.0)$ & $1(0.3)$ & $1(0.2)$ & $1(0.1)$ \\
\hline \multicolumn{8}{|c|}{ Who enforces the law against paying police a bribe to avoid getting into trouble? } \\
\hline Police/gendarmerie & $\begin{array}{r}228 \\
(75.7)\end{array}$ & $\begin{array}{r}242 \\
(80.1)^{*}\end{array}$ & $\begin{array}{r}470 \\
(77.9)\end{array}$ & $\begin{array}{r}212 \\
(69.7)\end{array}$ & $202(66.9)$ & $414(68.3)$ & $\begin{array}{r}884 \\
(73.1)\end{array}$ \\
\hline Courts & $13(4.3)$ & $4(1.3)$ * & $17(2.8)$ & $16(5.3)$ & $8(2.6)$ & $24(4.0)$ & $41(3.4)$ \\
\hline Social Action & $21(7.0)$ & $10(3.3)$ & $31(5.1)$ & $10(3.3)$ & $12(4.0)$ & $22(3.6)$ & $53(4.4)$ \\
\hline Someone else & $28(9.3)$ & $28(9.3)$ & $56(9.3)$ & $\begin{array}{r}43 \\
(14.1)\end{array}$ & $42(13.9)$ & $85(14.0)$ & $\begin{array}{r}141 \\
(11.7)\end{array}$ \\
\hline Don't know & $11(3.7)$ & $18(6.0)$ & $29(4.8)$ & $23(7.6)$ & 37 (12.3) & $60(9.9)$ & $89(7.4)$ \\
\hline Refused to answer & $0(0.0)$ & $0(0.0)$ & $0(0.0)$ & $0(0.0)$ & $1(0.3)$ & $1(0.2)$ & $1(0.1)$ \\
\hline Noles. & & & & & & & \\
\hline
\end{tabular}

The data indicate that $64 \%$ of respondents thought that the police are primarily responsible for enforcing FGM/C law, while $10 \%$ thought it was enforced by the courts, $5 \%$ by Social Action, and $12 \%$ did not know. Perception of who enforces the law against cutting wood in the forest follow a similar trend, with $65 \%$ thinking it was the police, $5 \%$ courts, $8 \%$ Social Action and $12 \%$ reporting 
that they did not know. With respect to paying police a bribe to avoid trouble, a slightly higher proportion was noted: $73 \%$ thought it was the police, while $3 \%$ thought it was the courts.

In terms of country-level comparison, there was a significant differences between the proportion of people respondents believed to be responsible for enforcing $F G M / C$ law $(p=0.046$ ), with a slightly higher proportion of respondents in Burkina Faso (12\%) than in Mali $(6 \%)$ thinking it was actually the courts that enforced the law against FGM/C. Proportions of those who thought it was the police (64\% in Burkina Faso and $66 \%$ in Mali) did not differ significantly by country. There were no significant differences by gender in terms of who respondents believe to be responsible for enforcing FGM/C law in both Burkina Faso $(p=0.051)$ and Mali $(p=0.053)$. Further details regarding respondents' perceptions on who enforces the FGM/C law, disaggregated by pair commune, are presented in Appendix Table 5.

It is important to note once again that the results in Mali are consistent with people believing that $\mathrm{FGM} / \mathrm{C}$ is illegal in Mali, while there is still no specific law banning FGM/C in that country. In both countries, the police and gendarmerie are the first line of intervention to arrest a person, and it is not surprising that they are perceived to be the first to enforce the law.

Respondents were also asked whether they thought someone would be punished if they were to plan to practise $\mathrm{FGM} / \mathrm{C}$. The same inquiries were made for cutting wood in the forest and paying the police a bribe to avoid trouble. Figure 7 shows the results for Burkina Faso and Mali, disaggregated by gender.

Figure 7: Proportion of respondents who thought a person would be punished for practising FGM/C compared to what they thought if they did other criminalised conduct

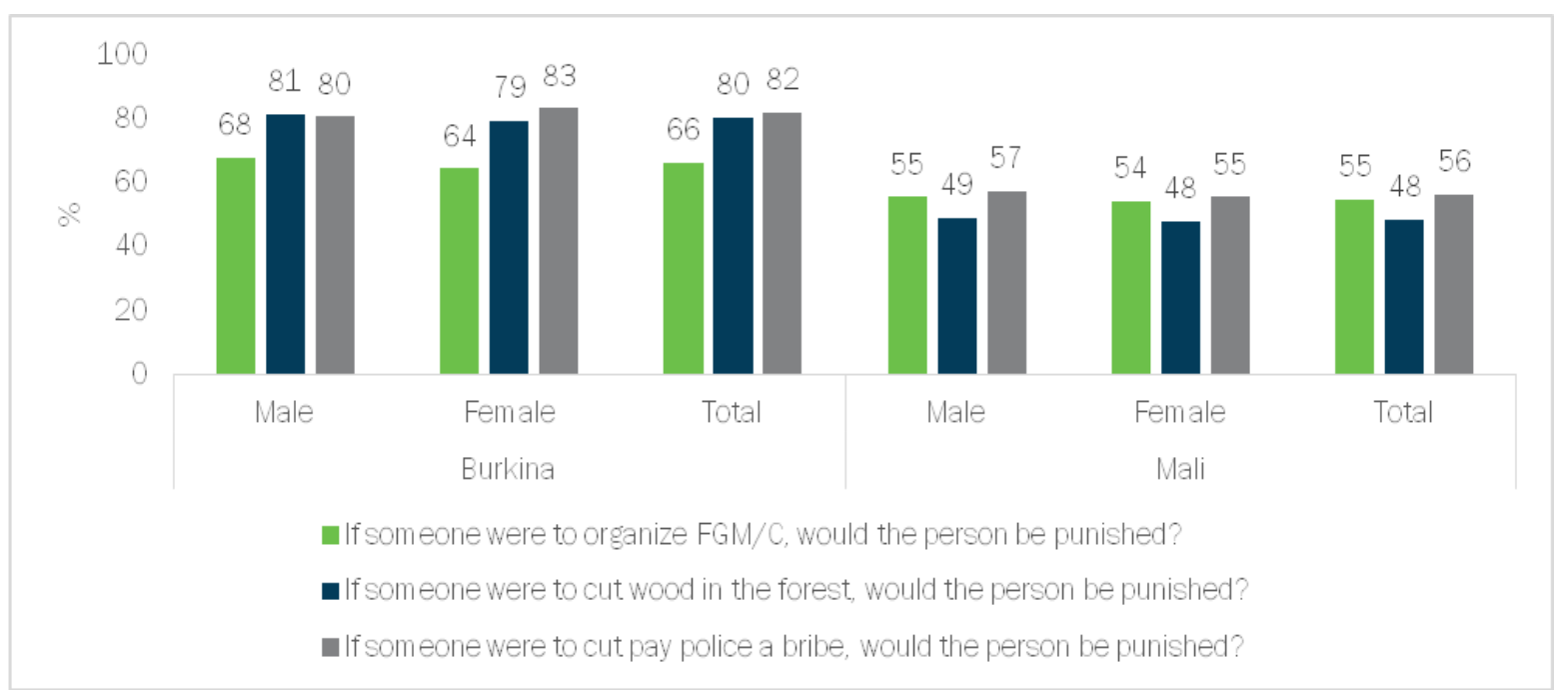

If someone were to organize an instance of $\mathrm{FGM} / \mathrm{C}, 66 \%$ of respondents in Burkina Faso and $55 \%$ of respondents in Mali thought that person would be punished. Compared to figures for $\mathrm{FGM} / \mathrm{C}$, the proportions of those who thought someone would be punished if the person were to cut wood in the forest $(80 \%)$ or pay police bribe to avoid trouble $(82 \%)$ was higher. Trends were similar by gender, with higher proportions of both male and female respondents saying that if someone was to cut wood in the forest ( $81 \%$ male, $79 \%$ female) or pay police a bribe to avoid trouble (79\% male, $83 \%$ female), that person would be punished, particularly as compared to the same figures for FGM/C (68\% male, 64\% female). In Mali however, there was no significant difference between the proportion of respondents who thought someone would be punished if that person were to organise $\mathrm{FGM} / \mathrm{C}(55 \%)$ as compared to some who had paid the police a bribe to avoid trouble (56\%). Proportions of those who thought someone would be punished if he/she cut wood in the forest were, however, slightly lower (48\%) and a similar trend was 
observed for both male and female respondents. These perceptions, disaggregated by pair commune, are presented in Appendix Table 5.

Overall, it is important to note that, in both countries, respondents perceived there to be a higher probability of getting punished when cutting wood in the forest or paying a bribe to the police to avoid trouble than when organizing FGM/C. And this is true despite the fact that Mali does not have a specific FGM law, while Burkina Faso does.

Respondents were also asked how, hypothetically, being arrested for practising FGM/C, would be perceived by the people they know best-whether these individuals would approve or disapprove of their arrest. Table 7 shows the overall results, as well as the results for Burkina Faso and Mali, disaggregated by gender within each country.

Table 7: Approval or disapproval of arrest of individuals for practising FGM/C compared to whether they practised other criminalised conduct

\begin{tabular}{|c|c|c|c|c|c|c|c|}
\hline & \multicolumn{3}{|c|}{ Burkina Faso } & \multicolumn{3}{|c|}{ Mali } & \multirow[b]{2}{*}{$\begin{array}{l}\text { Total } \\
(\mathrm{N}=1209)\end{array}$} \\
\hline & $\begin{array}{l}\text { Male } \\
(\mathrm{N}=301)\end{array}$ & $\begin{array}{l}\text { Female } \\
(\mathrm{N}=302)\end{array}$ & $\begin{array}{l}\text { Total } \\
(\mathrm{N}=603)\end{array}$ & $\begin{array}{l}\text { Male } \\
(\mathrm{N}=304)\end{array}$ & $\begin{array}{l}\text { Female } \\
(\mathrm{N}=302)\end{array}$ & $\begin{array}{l}\text { Total } \\
(\mathrm{N}=606)\end{array}$ & \\
\hline \multicolumn{8}{|c|}{ Disapprove of arrest for practising FGM/C? } \\
\hline Disapprove greatly & $117(38.9)$ & $111(36.8)$ & $228(37.8)$ & $112(36.8)$ & $104(34.4)$ & $\begin{array}{r}216 \\
(35.6)\end{array}$ & $444(36.7)$ \\
\hline Disapprove somewhat & $63(20.9)$ & $65(21.5)$ & $128(21.2)$ & $67(22.0)$ & $69(22.8)$ & $\begin{array}{r}136 \\
(22.4)\end{array}$ & $264(21.8)$ \\
\hline Disapprove a little & 63 (20.9) & $53(17.5)$ & $116(19.2)$ & $51(16.8)$ & $63(20.9)$ & $\begin{array}{r}114 \\
(18.8)\end{array}$ & $230(19.0)$ \\
\hline Do not disapprove & $55(18.3)$ & $58(19.2)$ & $113(18.7)$ & $72(23.7)$ & $54(17.9)$ & $\begin{array}{r}126 \\
(20.8)\end{array}$ & $239(19.8)$ \\
\hline Don't know & $3(1.0)$ & $15(5.0)^{*}$ & $18(3.0)$ & $2(0.7)^{*}$ & $11(3.6)$ & $13(2.1)$ & $31(2.6)$ \\
\hline Refused to answer & $0(0.0)$ & $0(0.0)$ & $0(0.0)$ & $0(0.0)$ & $1(0.3)$ & $1(0.2)$ & $1(0.1)$ \\
\hline \multicolumn{8}{|c|}{ Disapprove of arrest for cutting wood in the forest? } \\
\hline Disapprove greatly & $108(35.9)$ & $109(36.1)$ & $217(36.0)$ & $141(46.4)$ & $134(44.4)$ & $\begin{array}{r}275 \\
(45.4)^{\dagger}\end{array}$ & $492(40.7)$ \\
\hline Disapprove somewhat & $57(18.9)$ & $57(18.9)$ & $114(18.9)$ & $66(21.7)$ & $64(21.2)$ & $\begin{array}{r}130 \\
(21.5)\end{array}$ & $244(20.2)$ \\
\hline Disapprove a little & $48(15.9)$ & $58(19.2)$ & $106(17.6)$ & $43(14.1)$ & $44(14.6)$ & $87(14.4)$ & $193(16.0)$ \\
\hline Do not disapprove & $81(26.9)$ & $70(23.2)$ & $151(25.0)^{\dagger}$ & $51(16.8)$ & $52(17.2)$ & $\begin{array}{r}103 \\
(17.0)\end{array}$ & $254(21.0)$ \\
\hline Don't know & $7(2.3)$ & $8(2.6)$ & $15(2.5)$ & $3(1.0)$ & $7(2.3)$ & $10(1.7)$ & $25(2.10$ \\
\hline Refused to answer & $0(0.0)$ & $0(0.0)$ & $0(0.0)$ & $0(0.0)$ & $1(0.3)$ & $1(0.2)$ & $1(0.1)$ \\
\hline \multicolumn{8}{|c|}{ Disapprove of arrest for paying police a bribe to avoid trouble? } \\
\hline Disapprove greatly & $108(35.9)$ & $105(34.8)$ & $213(35.3)$ & $128(42.1)$ & $132(43.7)$ & $\begin{array}{r}260 \\
(42.9)^{\dagger}\end{array}$ & $473(39.1)$ \\
\hline Disapprove somewhat & $62(20.6)$ & $61(20.2)$ & $123(20.4)$ & $73(24.0)$ & $70(23.2)$ & $\begin{array}{r}143 \\
(23.6)\end{array}$ & $266(22.0)$ \\
\hline Disapprove a little & 60 (19.9) & 66 (21.9) & 126 (20.9) & $52(17.1)$ & $48(15.9)$ & $\begin{array}{r}100 \\
(16.5)\end{array}$ & $226(18.7)$ \\
\hline Do not disapprove & $63(20.9)$ & $62(20.5)$ & $125(20.7)^{\dagger}$ & $50(16.4)$ & $45(14.9)$ & $95(15.7)$ & $220(18.2)$ \\
\hline
\end{tabular}




\begin{tabular}{|c|c|c|c|c|c|c|c|}
\hline & \multicolumn{3}{|c|}{ Burkina Faso } & \multicolumn{3}{|c|}{ Mali } & \multirow[b]{2}{*}{$\begin{array}{l}\text { Total } \\
(\mathrm{N}=1209)\end{array}$} \\
\hline & $\begin{array}{l}\text { Male } \\
(\mathrm{N}=301)\end{array}$ & $\begin{array}{l}\text { Female } \\
(\mathrm{N}=302)\end{array}$ & $\begin{array}{l}\text { Total } \\
(\mathrm{N}=603)\end{array}$ & $\begin{array}{l}\text { Male } \\
(\mathrm{N}=304)\end{array}$ & $\begin{array}{l}\text { Female } \\
(\mathrm{N}=302)\end{array}$ & $\begin{array}{l}\text { Total } \\
(\mathrm{N}=606)\end{array}$ & \\
\hline Don't know & $8(2.7)$ & $8(2.6)$ & $16(2.7)$ & $1(0.3)$ & $6(2.0)$ & $7(1.2)$ & $23(1.9)$ \\
\hline Refused to answer & $0(0.0)$ & $0(0.0)$ & $0(0.0)$ & $0(0.0)$ & $1(0.3)$ & $1(0.2)$ & $1(0.1)$ \\
\hline
\end{tabular}

Slightly more than one-third of all respondents thought that the people they knew best would strongly disapprove of their arrest if they were arrested for practising FGM/C, 22\% would somewhat disapprove, $19 \%$ would disapprove just a little, while $20 \%$ would not disapprove at all. There is a similar trend in the data with respect to other activities. A higher percentage of the respondents thought the people they knew best would disapprove strongly $(40.7 \%)$ or somewhat strongly (20\%) if they were arrested for cutting wood in the forest, and disapprove greatly $(39 \%)$ or somewhat $(22 \%)$ if they were arrested for paying the police a bribe to avoid trouble.

There were no significant differences $(p=0.686)$ in the proportion of the respondents from Burkina Faso $(38 \%)$ and Mali (36\%) who thought that the people they knew best would disapprove greatly if they were arrested for practising FGM/C. There were, however, significant differences $(p=0.001)$ between the proportion of respondents from Burkina Faso (36\%) and Mali $(45 \%)$ who thought people would greatly disapprove if they were arrested for cutting wood in the forest. In addition, among people who though the people they know best would disapprove greatly if they were arrested for paying a bribe to the police, there was a significant difference $(p=0.003)$ between Burkina Faso (35\%) and Mali (43\%). There were no significant differences when the data were analysed by gender in both countries. In this case, slightly more than a third of respondents thought people they knew would greatly disapprove if they were arrested for practising any of the above criminalised activities, and about a fifth thought these same people would somewhat disapprove. Details related to these results, analysed by pair commune, are presented in Appendix Table 5.

It is worth noting that, though respondents in both countries stated their respect for the law, up to $59 \%$ in Burkina Faso would disapprove (greatly or somewhat) if people they knew were arrested for practising FGM/C. Local and social ties, and other local reasons, therefore, seem to be more important that the law.

\section{The List Experiment}

A list experiment is a technique used to elicit truthful responses to sensitive questions and to overcome desirability bias. Desirability bias is known to cause respondents to profer inaccurate responses. In the context of this study, the sensitive question that we sought to answer was whether an individual planned to continue practising FGM/C. List experiments require that the survey sample be randomly divided into two sub-samples and for one of the sub-samples to be read a list of not very sensitive activities and then asked to count how many of the items are true for the respondent. The other sub-sample is then provided the same list of activities, plus an extra activity related to the sensitive issue under study.

In this study, the overall sample of 1,209 was randomly divided in such a way that $50 \%$ of respondents received the control list, which included items 1 thru 5 below (and excluded the sensitive question). The other sub-sample then received all six items listed below (including the 
sensitive item). All respondents were asked to count the number of items they planned to do in the future and to report that number back to the enumerator.
1. Visit a sick relative
2. Cut woods in the bush/forest
3. Pay the police/gendarmerie a bribe to avoid trouble
4. Accuse a family member of witchcraft
5. Celebrate a religious holiday.
6. Circumcise my daughter or granddaughter

A two-sample t-test was used to compare the means of the two groups (Table 6). There was a significant difference $(p<0.001)$ between the mean number of responses, with the treatment group having a slightly higher mean (3.1) than the control group (2.9). If none of the respondents presented with \#6 planned to circumcise their daughter in the future, we would expect the means of the two groups to be the same (statistically), but since the mean was higher, we can deduce that some of the respondents do plan to circumcise daughters in the future. In all of the communes in Mali, there were significant differences between the mean number of activities reported by those in the treatment and control groups. In Burkina Faso, however, the difference in means was not significant $(p=0.20)$ across control and treatment groups in any commune $(p>0.05)$. These results are consistent with some degree of $F G M / C$ abandonment in Burkina Faso, even though lack of significance does not necessarily indicate that FGM/C has been fully abandoned in Burkina Faso, vis-à-vis Mali.

\section{Planned future prevalence estimation from the list experiment}

An estimate of planned FGM/C "prevalence" was estimated using a list experiment. Respondents were asked to report the total number of listed activities they planned to carry out "in the future." "Circumcise my daughter or granddaughter" was listed in the experimental/treatment condition, but not in the control. We were then able to obtain an estimate of planned FGM/C "prevalence" by computing the difference in the total counts between the treatment group and the control group, expressed as a fraction of the total number of individuals in the treatment group.

As indicated in Table 8 below, the above-described procedure and analysis resulted in an estimated planned "prevalence" of $28 \%$ among all respondents. Burkina Faso had an estimated planned "prevalence" of $14 \%$ while Mali had $44 \%$. All communes from Mali had a higher planned "prevalence estimate" compared to their comparative communes from Burkina Faso. The data suggest that the law in Burkina Faso may have had an effect on future plans to circumcise girls. 
Table 8: Estimation of planned future FGM/C prevalence using list experiment in Burkina Faso and Mali

\begin{tabular}{|c|c|c|c|c|c|c|c|}
\hline & Treatment group (T) & & Control group & & & & \\
\hline & $\begin{array}{r}\text { Mean } \\
(95 \% \mathrm{Cl})\end{array}$ & $\begin{array}{r}\text { Total } \\
\left(T_{t}\right)\end{array}$ & $\begin{array}{r}\text { Mean } \\
(95 \% \mathrm{Cl})\end{array}$ & Total $\left(\mathrm{C}_{\mathrm{t}}\right)$ & $\begin{array}{r}\text { T- } \\
\text { Test }\end{array}$ & $\begin{array}{l}\mathrm{Pr} \\
(\mathrm{T}>\mathrm{C})\end{array}$ & $\begin{array}{r}\text { Prevalence }(\%) \\
\text { estimate }\left(T_{t}-\right. \\
\left.C_{t}\right) / n_{t}\end{array}$ \\
\hline Overall & $3.1(3.0,3.2)$ & 1774 & $2.9(2.8,2.9)$ & 1817 & 3.6 & $<0.001$ & 28.4 \\
\hline \multicolumn{8}{|l|}{ Country } \\
\hline Burkina & $2.8(2.7,3.0)$ & 856 & $2.7(2.6,2.8)$ & 815 & 1.3 & 0.20 & 13.5 \\
\hline Mali & $3.4(3.2,3.5)$ & 1026 & $3.0(2.9,3.1)$ & 894 & 3.7 & $<0.001$ & 43.6 \\
\hline \multicolumn{8}{|c|}{ Paired Communes } \\
\hline Faramana & $2.8(2.5,3.0)$ & 281 & $2.7(2.5,2.8)$ & 269 & 0.6 & 0.53 & 11.8 \\
\hline Koury & $3.3(3.1,3.6)$ & 341 & $2.9(2.7,3.1)$ & 291 & 2.5 & 0.01 & 49.0 \\
\hline Koloko & $2.9(2.7,3.1)$ & 291 & $2.7(2.5,2.9)$ & 266 & 1.3 & 0.19 & 24.8 \\
\hline Finkolo & $3.5(3.2,3.8)$ & 357 & $3.1(2.8,3.3)$ & 305 & 2.7 & 0.008 & 51.5 \\
\hline Tansila & $2.8(2.6,3.1)$ & 284 & $2.8(2.6,3.0)$ & 280 & 0.3 & 0.79 & 4.0 \\
\hline Boura & $3.2(2.9,3.5)$ & 328 & $3.0(2.8,3.2)$ & 298 & 1.2 & 0.23 & 29.1 \\
\hline
\end{tabular}

Notes:

1. Prevalence was estimated as the difference between the total number of activities by the treatment group and the control group expressed as a fraction of the total number of respondents in the treatment group.

2. $\mathrm{n}_{\mathrm{t}}$ is the number of individuals in the treatment group.

We also examined cross-border differences in the mean number of reported activities and performed a two-sample t-test to compare these differences on a country basis. Table 9 presents these results in terms of overall cross-border differences, as well as pair commune differences.

Table 9: Burkina Faso-Mali cross-border comparison of the mean number of activities reported by the respondents randomized in the treatment group

\begin{tabular}{|c|c|c|c|c|}
\hline & Burkina Faso (B) & Mali (M) & & \\
\hline & Mean $(95 \% \mathrm{Cl})$ & Mean $(95 \% \mathrm{Cl})$ & T-Test & $\operatorname{Pr}\left(B_{m}=M_{m}\right)$ \\
\hline Burkina/Mali & $2.8(2.7,3.0)$ & $3.4(3.2,3.5)$ & -5.0 & $<0.001$ \\
\hline \multicolumn{5}{|l|}{ Paired communes } \\
\hline Faramana/Koury & $2.8(2.5,3.0)$ & $3.3(3.1,3.6)$ & -3.2 & $<0.001$ \\
\hline Koloko/Finkolo & $2.9(2.7,3.1)$ & $3.5(3.2,3.8)$ & -3.6 & $<0.001$ \\
\hline Tansila/Boura & $2.8(2.6,3.1)$ & $3.2(2.9,3.5)$ & -1.9 & 0.030 \\
\hline \multicolumn{5}{|l|}{ Notes } \\
\hline \multicolumn{5}{|c|}{$\mathrm{B}_{\mathrm{m}}=$ Mean of number of activities reported by participants in the treatment group in Burkina Faso. } \\
\hline \multicolumn{5}{|c|}{$\mathrm{M}_{\mathrm{m}}=$ Mean of number of activities reported by participants in the treatment group in Mali } \\
\hline
\end{tabular}

The mean number of activities reported by respondents in Mali was higher than those in Burkina Faso $(p<0.001)$ and a similar trend replicates itself across paired communes.

In order to cross-check our quantitative findings with the qualitative data, we focused on Boura (29.1) and Tansila (4.0), where planned future "prevalence" was lowest. 
From the point of view of our key informants and FGD participants, some people in their communities continue to practice FGM/C underground: crossing the border to Mali to have girls cut, or cutting girls during the rainy season, or cutting them at a younger age "when the baby is still at her mother's back." These practices are mostly linked to tradition in Burkina Faso, or to religion and tradition in Mali, but also to pressure from elders and other gatekeepers of customary norms and practices. The excerpts below from qualitative transcripts should help illustrate what individuals in Boura and Tansila believe prevalence rates to be, as well as why and how they believe the practice continues.

"I have the impression that the tradition occupies a more important place than we think. Some have agreed to give it up, but others continue to cut."

Female, FGD 35+, Boura, Mali

"We have learned that FGM/C is not good. The elders used to say that during childbirth it will be easy when you are cut, but if you are uncut it will be difficult during childbirth; that is why some adults women are cut during childbirth. Today, they cut before the birth. "

Female, FGD 18-34, Boura, Mali

There seems to be an intergenerational dispute over whether or not to cut, and our participants were openly against the practice and blaming the elders and the traditions. The cutters are those who help perpetuate the traditions of cutting. Participants also believed that the practice would decrease when the elders who strongly support it were no longer in this world. In addition, as the cutters are getting older and will one day die, chances are that there would be no more providers.

"In the past, all households used to cut their girls. Today you will find that some people still practise it and others do not. If some people continue to cut, it is because there are cutters that are still around, but if they're no longer there, the practise will stop [laughters]."

Male, FGD 35+, Tansila, Burkina Faso

"We had an association called 'deenba djè' which had received FGM/C training from the Catholic church. After the training, we dedicated our body and soul to the fight against FGM/C, which led to disagreements between us and our mothers. Personally, none of my four daughters have been cut. For this reason, my mother-in-law spent all her time insulting me and telling me that I had taken over the children."

Female, FGD 35+, Boura, Mali

"[...] because those who used to do the practice are no longer here [they are dead]."

Male, FGD 18-34, Tansila, Burkina Faso

However, the majority of participants believe that the practice is declining and that it will continue to do so. The reasons are multidimensional. People in Burkina Faso most fear the harsh FGM/C law, and in Mali people most fear the health consequences of a cutting that may turn wrong: a death of the girl or hemorrhage after cutting. In both cases, they will have to deal with the FGM/C law (in Burkina Faso) and law on physical harm (in Mali). These health and death risks were recurrent themes in the FGD discussions with men and women in Tansila/Boura regardless of their age. They believe that this fear led some parents to abandon the practice and that others will do so in the future. Hence, they strongly oppose FGM/C.

"In any case, I think there are no advantages in FGM/C. People used to say in the past that 
FGM/C was a way to avoid infidelity. While today, with the evolution of the science, it has been shown that FGM/C itself causes certain diseases that can affect women's reproductive health. Diseases such as tetanus, syphilis, and other infections."

Female, FGD 18-34, Tansila, Burkina Faso

"In some areas such as Marala [the participant makes a gesture to indicate a direction], there are women who have up to 7 children but who have not been cut; there are some people who do not do it anymore. My daughter who accompanied you [the research assistant] is not cut, nor is her younger sister. The people in our household have not accepted to cut their daughters because they say there are consequences. They refused to cut their daughter."

Female, FGD 35+, Boura, Mali

"FGM/C for me, well, it has no advantage. The customary leaders in the past acted as if it were a custom. However, this is not a custom. I don't see any advantages."

Male, FGD 18-34, Boura, Mali

"We were told that an uncut woman has complications during childbirth compared to a woman who is cut. That's what people used to say when FGM/C was practised, but now [laughter], now we no longer practise it here but our daughters who are cut have no problems during childbirth; on the contrary, they give birth more easily. Anyway, I don't see any advantages to FGM/C."

Male, FGD 35+, Tansila, Burkina Faso

In summary, the FGD data support the list experiment's projection of a decrease in FGM/C in both villages. But data from health worker key informants are also important, because they are in a position to know whether a woman or girl is cut or not. The two health workers who were interviewed in Tansila had divergent points of view on the current state of FGM/C practise. The first one confirmed that he delivered young women that are uncut, while the other reported that the younger and older women he has delivered are all cut. Excerpts from their transcripts are below.

Given your position here, at the health centre, do you really think that people have stopped the practise of $\mathrm{FGM} / \mathrm{C}$ ?

"Yes! When I say yes, it is because I receive many women in my health centre, and I can say that people have stopped the practise of FGM/C a lot. Because most of the cases we see are really women who may already have more than six children, and if we take their ages and go back in time, we will find that the practise has already been done a long time ago. But with the younger girls we meet today, we really feel that there are many who have not been cut. So, I can say that with this comparison already, the practise has really decreased."

Male, KII, Tansila, Burkina Faso

"As far as I know, almost all the women we dealt with during childbirth are all circumcised."

Young and old alike?

"Yes, young and old, so I tell myself that FGM/C is still practised but clandestinely. Otherwise I eould have seen the girls who are cut. And I can say that since I've been here, since I've been delivering babies, I've never found an uncut girl."

Male, KII, Tansila, Burkina Faso 
This divergence in experience is noteworthy and leads one to wonder why, in the same village, one health worker delivered uncut girls/women and the other did not. It may be that the second health worker joined the village recently, as noted by our research assistant.

\section{Compliance Motivations}

This section investigates what motivates people born into a tradition of FGM/C to obey, or not obey, a law prohibiting the practice.

\section{Motivations to obey the law}

Respondents were asked what motivated them to obey the statutory law and the customary law. Figure 8 shows what motivates respondents themselves, as well what respondents believe motivates others to obey the statutory law.

Figure 8: Individual motivations to obey statutory law

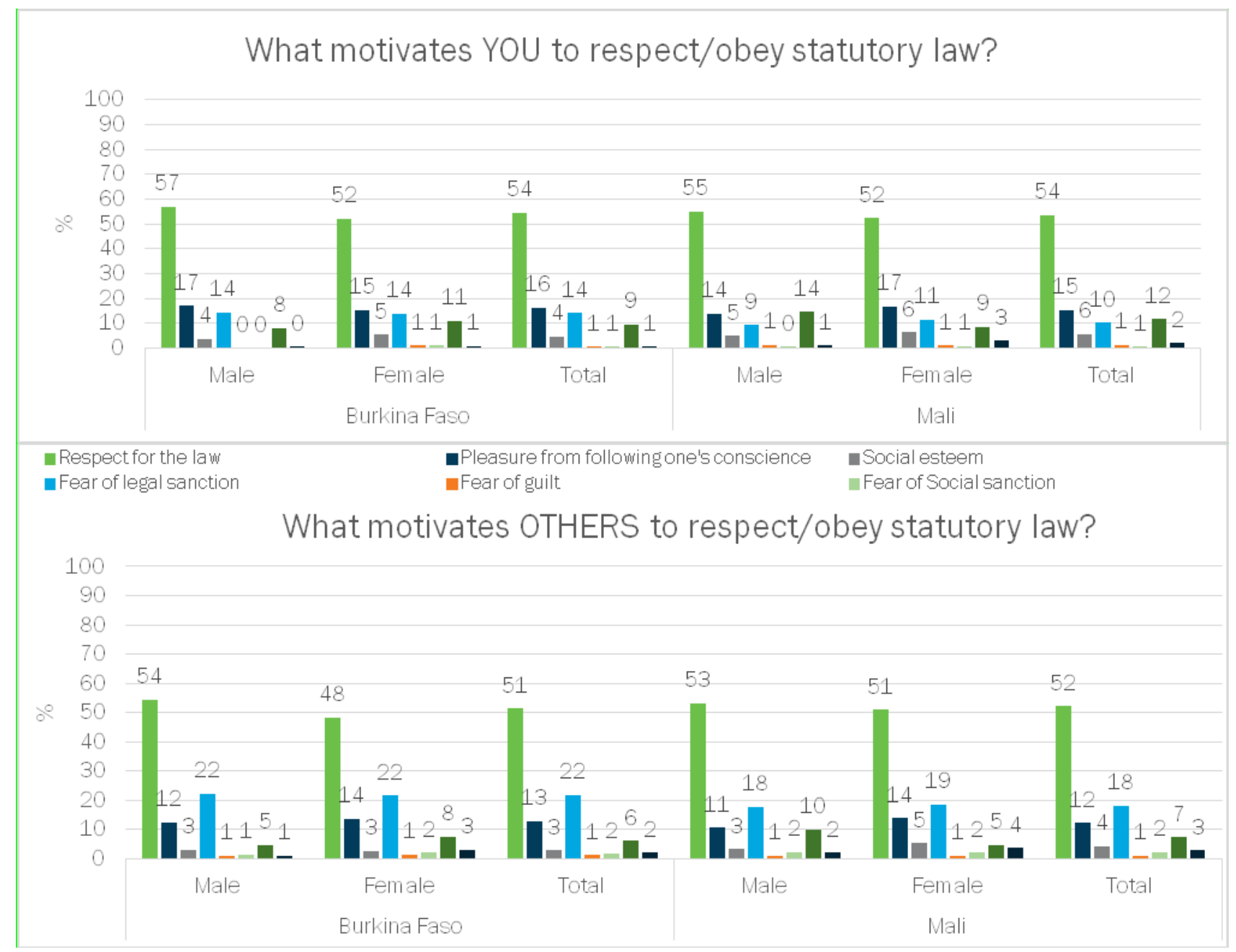

Respect for the law was the most important motivator for respondents (individually) to obey the statutory law (first panel in Figure 9), with $54 \%$ of all respondents reporting this when interviewed. There was no significant difference between the countries on this factor $(p=0.081)$. Pleasure from following one's conscience and fear of legal sanction were also mentioned by $16 \%$ and $12 \%$ of the respondents, respectively. Other factors included social esteem, fear of guilt and fear of social sanctions. 
There was also no significant difference between responses by gender in both Burkina Faso and Mali in terms of what motivated respondents to obey the formal law, with $55 \%$ of male respondents and $48 \%$ of female respondents in Burkina Faso thinking respect for the law was the main factor that motivated them to obey the statutory law. In Mali, $53 \%$ and $51 \%$ of male and female respondents, respectively, also thought respect for the law was the main motivating factor for them.

When asked what they thought motivated others to obey the statutory law, respect for the law was still reported as the main factor by $52 \%$ of respondents, with $13 \%$ and $20 \%$, respectively, saying others would be motivated by the pleasure they get from following their own conscience and fear of legal sanction.

In summary, respondents (individually) obey the law most often because of a sense of legal obligation and they believe others behave similarly. Fear of legal sanction comes in as only the second or third reason. Hence punishment does not seem to be what induces people to obey the law. These data suggest that we should rethink the harshness of the penalties associated with FGM/C and other laws. Appendix Table 6 details tesults, disaggregated by pair commune.

We also sought to know whether respondents' motivation to obey statutory law was the same or different from their motivation to obey customary law. Figure 9 shows what respondents believe motivates them (individually) to obey customary law and what they believe motivates others.

Figure 8: Individual motivations to obey customary law

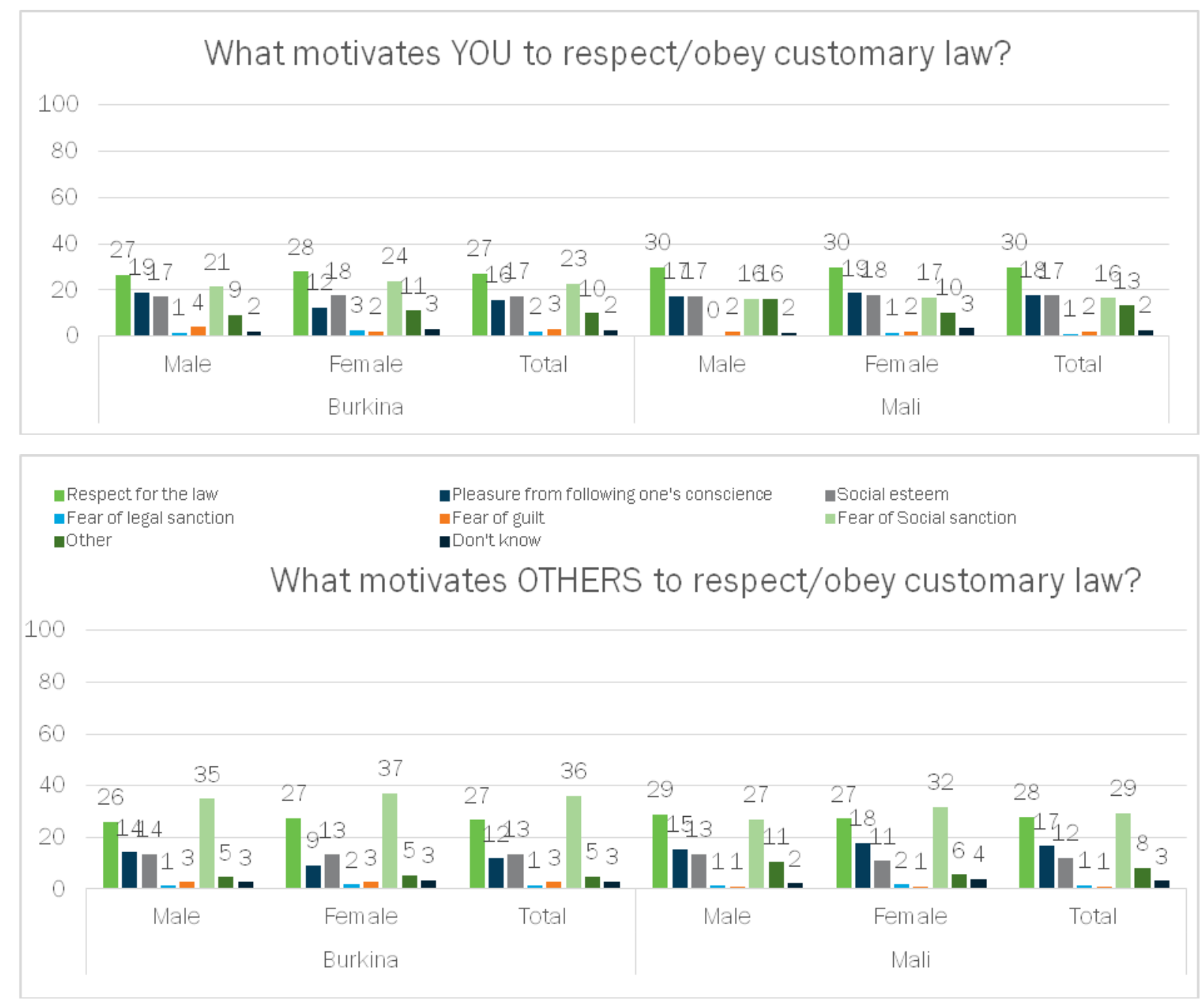


Overall, $28 \%$ of all respondents thought that respect for the law motivated them to obey customary law. The pleasure one gets from following one's conscience and social esteem were each reported by $17 \%$ of the respondents. Notably, about one-fifth of respondents said fear of social sanctions (ancestors, gods, etc.) motivated them to obey customary law. There was a marginally significant difference by country $(p=0.05)$ on this particular question, with the proportion of respondents who reported fear of social sanctions being $23 \%$ in Burkina Faso and only $16 \%$ in Mali.

The data suggest a different pattern when respondents were asked what they thought motivated others to obey customary law. Fear of social sanctions was reported by a relatively higher proportion of the respondents (33\%). The social sanctions can be social isolation and marginalisation within the community; they can also include something mystic that would happen to the individual who does not obey the local rules (a weird illness, disability, or a sudden death). The French word "fétiches" [something mystical] was recurrent in the responses of the qualitative participants. Respect for the law was mentioned by $27 \%$ of respondents, and this is approximately equivalent to what motivated the respondents individually, as reported above. There were also significant differences in the proportion of responses by country, with $36 \%$ of the respondents from Burkina Faso and $29 \%$ of the respondents from Mali mentioning fear of social sanctions as the main factor motivating others to obey customary law. Notably, $12 \%$ of respondents from Burkina Faso, compared to 17\% of respondents from Mali said that pleasure from following one's conscience was their main motivating factor, with $3 \%$ in Burkina Faso, compared to $1 \%$ in Mali, saying they were motivated by fear or guilt. There were, however, no significant differences by gender in either Burkina Faso $(p=0.230)$ or Mali $(p=0.373)$ on what motivated respondents (individually) to obey customary law, nor were there differences in terms of what respondents believed motivated others. (Appendix Table 7).

\section{Motivations to disobey the law}

When asked when people in their communities think it is permissible to disobey statutory law, $28 \%$ of all respondents thought it would be permissible if it contradicts religion/custom, $28 \%$ thought it would be permissible when they themselves do not agree with the law, $23 \%$ thought it would be permissible when authorities do not respect the law themselves, and $13 \%$ said it would be permissible if there were no sanctions for non-application of the law. When asked about customary law (Table 10), 51\% said it would be permissible to disobey customary law if it contradicts religion and $7 \%$ thought it would be permissible when it contradicts statutory law. 
Table10: When would it be permissible to disobey the statutory or customary law?

\begin{tabular}{|c|c|c|c|c|c|c|c|}
\hline & \multicolumn{3}{|c|}{ Burkina } & \multicolumn{3}{|c|}{ Mali } & \multirow[t]{2}{*}{ Total } \\
\hline & $\begin{array}{l}\text { Male } \\
(\mathrm{N}=301)\end{array}$ & $\begin{array}{l}\text { Female } \\
(\mathrm{N}=302)\end{array}$ & $\begin{array}{l}\text { Total } \\
(\mathrm{N}=603)\end{array}$ & $\begin{array}{l}\text { Male } \\
(\mathrm{N}=304)\end{array}$ & $\begin{array}{l}\text { Female } \\
(\mathrm{N}=302)\end{array}$ & $\begin{array}{l}\text { Total } \\
(\mathrm{N}=606)\end{array}$ & \\
\hline \multicolumn{8}{|c|}{ When would it be permissible to disobey the statutory law? } \\
\hline $\begin{array}{l}\text { Contradicts with } \\
\text { religion/custom }\end{array}$ & $79(26.2)$ & $91(30.1)$ & $170(28.2)$ & $83(27.3)$ & $85(28.1)$ & $168(27.7)$ & $338(28.0)$ \\
\hline I do not agree with the law & $77(25.6)$ & $87(28.8)$ & $164(27.2)$ & $82(27.0)$ & $97(32.1)$ & $179(29.5)$ & $343(28.4)$ \\
\hline $\begin{array}{l}\text { The authorities do not respect } \\
\text { the law }\end{array}$ & $58(19.3)$ & $61(20.2)$ & $119(19.7)$ & $94(30.9)$ & $61\left(20.2^{*}\right)$ & $155(25.6)$ & $274(22.7)$ \\
\hline $\begin{array}{l}\text { No sanctions for non- } \\
\text { application of the law }\end{array}$ & $44(14.6)$ & $50(16.6)$ & $94(15.6)$ & $30(9.9)$ & $38(12.6)$ & $68(11.2)$ & $162(13.4)$ \\
\hline Other & $92(30.6)$ & $55(18.2)^{*}$ & $147(24.4)$ & $80(26.3)$ & $58\left(19.2^{*}\right)$ & $138(22.8)$ & $285(23.6)$ \\
\hline Don't know & $17(5.6)$ & $25(8.3)$ & $42(7.0)$ & $4(1.3)$ & $23(7.6)^{*}$ & $27(4.5)$ & $69(5.7)$ \\
\hline Refused to answer & $1(0.3)$ & $0(0.0)$ & $1(0.2)$ & $0(0.0)$ & $0(0.0)$ & $0(0.0)$ & $1(0.1)$ \\
\hline \multicolumn{8}{|c|}{ When would it be permissible to disobey the customary law? } \\
\hline $\begin{array}{l}\text { Contradicts with } \\
\text { religion/custom }\end{array}$ & $153(50.8)$ & $155(51.3)$ & $308(51.1)$ & $150(49.3)$ & $154(51.0)$ & $304(50.2)$ & $612(50.6)$ \\
\hline Exceeded law/backwards & $68(22.6)$ & $78(25.8)$ & $146(24.2)$ & $67(22.0)$ & $61(20.2)$ & $128(21.1)$ & $274(22.7)$ \\
\hline $\begin{array}{l}\text { Contradicts with the statutory } \\
\text { law }\end{array}$ & $28(9.3)$ & $19(6.3)$ & $47(7.8)$ & $16(5.3)$ & $16(5.3)$ & $32(5.3)$ & $79(6.5)$ \\
\hline Too restrictive & $65(21.6)$ & $62(20.5)$ & $127(21.1)$ & $52(17.1)$ & $53(17.5)$ & $105(17.3)$ & $232(19.2)$ \\
\hline Segregationist law & $30(10.0)$ & $21(7.0)$ & $51(8.5)$ & $31(10.2)$ & $21(7.0)$ & $52(8.6)$ & $103(8.5)$ \\
\hline Other & $35(11.6)$ & $41(13.6)$ & $76(12.6)$ & $64(21.1)$ & $53(17.5)$ & $117(19.3)$ & $193(16.0)$ \\
\hline Don't know & $11(3.7)$ & $15(5.0)$ & $26(4.3)$ & $5(1.6)$ & $18(6.0)^{*}$ & $23(3.8)$ & $49(4.1)$ \\
\hline Refused to answer & $0(0.0)$ & $0(0.0)$ & $0(0.0)$ & $0(0.0)$ & $2(0.7)$ & $2(0.3)$ & $2(0.2)$ \\
\hline
\end{tabular}

Note: * significant at 0.05 significance level.

There were significant differences between the proportions of respondents who said it would be permissible to disobey the statutory law $(p=0.02)$ in Burkina Faso $(20 \%)$ and Mali $(26 \%)$. A significant difference was also observed between Burkina Faso (16\%) and Mali $(11 \%)$ in the proportion of respondents who thought it would be permissible to disobey the statutory law if there were no sanctions for non-application of the law (noncompliance) $(p=0.03)$. There were, however, no significant differences between Burkina Faso and Mali in terms of whether respondents thought it would be permissible to disobey the customary law $(p>0.05)$.

In Mali, significant differences were observed between the proportion of male respondents $(31 \%)$ and female respondents $(20 \%)$ who thought it would be permissible to disobey statutory law when the authorities themselves do not obey/respect the law. There were no significant differences, however, in terms of the proportions of respondents in the other categories when analysed by gender in both Burkina Faso and Mali. Results, disaggregated by pair commune, are presented in Appendix Tables 8 and 9.

\section{When is it acceptable to disobey Burkina Faso and/or Mali's statutory law?}

Table 11 shows the proportions of respondents who believe a particular situation would make it acceptable to disobey Burkina Faso's and/or Mali's statutory law. The data show the overall 
proportion, as well as a cross-country comparison; they are also disaggregated by gender within each country.

Table 11: When is it acceptable to disobey Burkina Faso's/Mali's Statutory law?

\begin{tabular}{|c|c|c|c|c|c|c|c|}
\hline \multirow[b]{2}{*}{$\begin{array}{l}\text { It is acceptable to break/disobey Burkina } \\
\text { Faso/Mali statutory law: }\end{array}$} & \multicolumn{3}{|c|}{ Burkina Faso } & \multicolumn{3}{|c|}{ Mali } & \multirow{2}{*}{$\begin{array}{c}\text { Total } \\
(\mathrm{N}=1209)\end{array}$} \\
\hline & $\begin{array}{l}\text { Male } \\
(\mathrm{N}=301)\end{array}$ & $\begin{array}{l}\text { Female } \\
(\mathrm{N}=302)\end{array}$ & $\begin{array}{l}\text { Total } \\
(\mathrm{N}=606)\end{array}$ & $\begin{array}{l}\text { Male } \\
(\mathrm{N}=304)\end{array}$ & $\begin{array}{l}\text { Female } \\
(\mathrm{N}=302)\end{array}$ & $\begin{array}{l}\text { Total } \\
(\mathrm{N}=606)\end{array}$ & \\
\hline $\begin{array}{l}\text { If this law is clearly against one's moral } \\
\text { principles (Yes) }\end{array}$ & $187(62.1)$ & $201(66.6)$ & $\begin{array}{l}388 \\
(64.3)\end{array}$ & $196(64.5)$ & $197(65.2)$ & $\begin{array}{l}393 \\
(64.9)\end{array}$ & $781(64.6)$ \\
\hline $\begin{array}{l}\text { If one would find it too costly to obey this } \\
\text { law (Yes) }\end{array}$ & $123(40.9)$ & $131(43.4)$ & $\begin{array}{l}254 \\
(42.1)\end{array}$ & $123(40.5)$ & $149(49.3)^{*}$ & $\begin{array}{l}272 \\
(44.9)\end{array}$ & $526(43.5)$ \\
\hline $\begin{array}{l}\text { If one knows that this law is not enforced } \\
\text { (Yes) }\end{array}$ & $171(56.8)$ & $181(59.9)$ & $\begin{array}{l}352 \\
(58.4)\end{array}$ & $190(62.5)$ & $196(64.9)^{*}$ & $\begin{array}{l}386 \\
(63.7)\end{array}$ & $738(61.0)$ \\
\hline $\begin{array}{l}\text { If one knows that most of the people he or } \\
\text { she knows best do not follow this law (Yes) }\end{array}$ & $91(30.2)$ & $128(42.4)^{*}$ & $\begin{array}{l}219 \\
(36.3)\end{array}$ & $105(34.5)$ & $126(41.7)^{*}$ & $\begin{array}{l}231 \\
(38.1)\end{array}$ & $450(37.2)$ \\
\hline If one does not know about this law (Yes) & $195(64.8)$ & $216(71.5)$ & $\begin{array}{l}411 \\
(68.2)\end{array}$ & $222(73.0)$ & $226(74.8)$ & $\begin{array}{l}448 \\
(73.9)\end{array}$ & $859(71.1)$ \\
\hline $\begin{array}{l}\text { If one thinks that this law was made without } \\
\text { representing the interests of people like him } \\
\text { or her (Yes) }\end{array}$ & $153(50.8)$ & $170(56.3)$ & $\begin{array}{l}323 \\
(53.6)\end{array}$ & $172(56.6)$ & $183(60.6)$ & $\begin{array}{l}355 \\
(58.6)\end{array}$ & $678(56.1)$ \\
\hline $\begin{array}{l}\text { If one thinks this law is enforced unfairly } \\
\text { (Yes) }\end{array}$ & $195(64.8)$ & $213(70.5)^{*}$ & $\begin{array}{l}408 \\
(67.7)\end{array}$ & $219(72.0)$ & $218(72.2)$ & $\begin{array}{l}437 \\
(72.1)\end{array}$ & 845 (69.9) \\
\hline
\end{tabular}

Note: *Significant at 5\% significance level.

Overall, $70 \%$ of the respondents thought it would be acceptable to break the law if one thought the law was enforced unfairly, $65 \%$ said it would be acceptable if the law was clearly against one's moral principles, $44 \%$ if one finds it too costly to obey the law, $56 \%$ if one thinks that the law was made without representing the interests of people like him/her, and $71 \%$ thought it would be acceptable if one did not know about the law. The proportion of respondents who thought it would be acceptable to break the statutory law were significantly different between Burkina Faso $(68 \%)$ and Mali $(74 \%)(p=0.046)$. The proportions of respondents who agreed to all other situations listed in Table 11 were not significantly different between the two countries. In both Burkina Faso and Mali, significant differences $(p<0.05)$ were observed, however, in the proportion of male and female respondents who agreed that it would be acceptable to break the statutory law if one knew that most of the people one knows best would approve of breaking that law, and also if one knew that most of the people one knows best do not follow that law. A higher proportion of female than male respondents was observed in both cases (Table 11).

\section{How the design and administration of the legal implementation strategy affects the choice to obey}

We asked qualitative research participants for their thoughts on FGM/C law. In Burkina Faso, almost all key informants who opposed FGM/C said it was a good law despite the fact that they did not know much about the content of the law. They did know that anyone who was caught practising $\mathrm{FGM} / \mathrm{C}$ was at risk for jail time and fines. They also believe that the design of the law was necessary to protect girls from FGM/C health consequences (hemorrhage, death, problems during childbirth, infections, etc.). Participants in Mali were also supportive of Burkina Faso's 
FGM/C law. Some knew nothing about the law, but when briefed about its contents, they were supportive and even insisted that Mali must have the same law. In fact, regardless of the village and the country, all those who opposed FGM/C still believed that the law was a good tool and it should be enforced more effectively to better punish those doing the cutting underground. This highlights the fact that enforcement of the law remains a challenge in remote areas in Burkina Faso. The transcript excerpts below illustrate how respondents think about FGM/C law.

What do you think about Burkina Faso's FGM/C law ?

"I think it is a very good example that Mali should follow to really put an end to this clandestine practise of FGM/C. If we have a specific law, it is good because the very presence of the law itself is a deterrent. And as soon as we start to seriously punish those who continue to cut, you will see that the others will give it up, there will be no more customers at all."

Male, KII, Koury, Mali

Why do you say the Burkina FGM/C law is a good law?

"Because it protects girls and women and prevent them from hardship, but the enforcement of such a law is difficult here, people are still hiding to cut. If the law were properly applied, we would like it."

Female, KII, Kokoko, Burkina Faso

\section{Conflict between customary law and statutory law}

Qualitative research participants were asked about conflicts between customary law and statutory law. Participants in both countries talked about child marriage, FGM/C, and the way in which the two laws resolve conflicts. Child marriage and FGM/C are both considered by international law to be harmful practises to girls and women. Yet, these practises are widespread in the study sites in both countries, as our data demonstrate. Participants explained that FGM/C and child marriage are cultural practises passed down from their ancestors, and that many people resist abandoning them; this is, in part, because some do not even understand why they should stop practising FGM/C. The statutory law has fixed a legal age of marriage which the communities do not use/recognise. Most people do not even know that there is a legal age of marriage, as some parents have brought their 16 year-old daughters to the civil hall to celebrate their civil marriages. From a local perspective, a girl is ready to be married when her breasts develop, when she begins to menstruate, or when her parents feel that she starts to get interested in "boys." Child marriage, whether forced or arranged, is part of the everyday lives of the people in our study sites.

It is worth noting here that $F G M / C$ is a practice influenced by social norms and is usually culturally justified, but some populations also believe that the advantages of continuing the practice outweigh the drawbacks. Participants in Mali study sites were more prone to speak in favour of FGM/C. Indeed, a government representative even said openly that they support $\mathrm{FGM} / \mathrm{C}$ because of their religion and culture, before concluding the interview by saying that their daughters were just cut a week before the RAs had come to the village.

The transcript excerpts below illustrate how respondents think about conflicts between statutory and customary law, FGM/C, and child marriage.

"People here are used to giving their daughters away whenever they want. There is also this problem that exists. However, as of today in Mali, everyone knows that forced marriage is not allowed, nor is the abduction of women, which is also punishable. Everyone in Mali knows that, but the repression is not easy, and it is also related to the different communities. It is a part of their practises." 
Male, KII, Koury, Mali

"The two laws contradict each other on other subjects such as marriage. From the point of view of customary or religious law, a girl even at 14 can be married. Yet modern law prohibits this; this too is a point of disagreement."

Male, KII, Faramana, Burkina Faso

On what subjects are the two laws in conflict?

"From my point of view, FGM/C is part of it because according to modern law FGM/C is a bad thing, yet from the point of view of customary law some people think that a girl who is not cut is full of sexual pleasure, others also say that it is not right; in fact many things are said. For me, this is where these laws are in conflict. Some religious and also some master preachers say that they cut their daughters, yet modern law prohibits it."

Female, KII, Faramana, Burkina Faso

Respondents also highlighted some aspects of statutory and customary law that are inherently contradictory. For instance, with respect to most statutory law, conflict resolution is based on enforcement and punishment. The outcome in the vast majority of situations is exacted against an individual. This fact stands in contrast to how customary law resolves disputes. Customary law tends to focus on conciliation, finding a solution that is best for the community, not the individual. Some participants were in favour of statutory law because they found that it was fair and focused on the rights of the individual, particularly those of women and children, who do not have much of a voice in customary law proceedings.

"Often at the level of inheritance there is a blockage, there is a total disconnect between customary law and national law, but generally people apply the customary law without problem and find that it works very well, but every time that the modern devices of justice are seized and begin to apply on these issues, it is a real problem because in the collective conscience they cannot understand that members of the same family brought each other to the authorities or to the courts to settle disputes."

Male, KII, Koury, Mali

"The two are sometimes in conflict; most of the time people do not trust the positive law [the civil law] because they think there is an injustice and the law is not for all cases. In reality this is what the average citizen thinks. He thinks the law is never applicable. It is the richest one who always wins. That's it!'

KII, Male, Koury, Mali

\section{Reasons why women and girls undergo FGM/C}

\section{Religious and traditional beliefs regarding FGM/C practise}

Respondents were asked whether they believed that FGM/C is permitted by their religion and customs. Their responses were then compared with responses on "cutting wood in the forest" and "paying the police a bribe to avoid trouble." Table 12 shows these results, disaggregated by country and by gender. 
Table 12: Perceptions on whether FGM/C is permitted by religion and customs

\begin{tabular}{|c|c|c|c|c|c|c|c|}
\hline & \multicolumn{3}{|c|}{ Burkina Faso } & \multicolumn{3}{|c|}{ Mali } & \multirow{2}{*}{$\begin{array}{l}\text { Total } \\
(\mathrm{N}=1209)\end{array}$} \\
\hline & $\begin{array}{l}\text { Male } \\
(\mathrm{N}=301)\end{array}$ & $\begin{array}{l}\text { Female } \\
(\mathrm{N}=302)\end{array}$ & $\begin{array}{l}\text { Total } \\
(\mathrm{N}=603)\end{array}$ & $\begin{array}{l}\text { Male } \\
(\mathrm{N}=304)\end{array}$ & $\begin{array}{l}\text { Female } \\
(\mathrm{N}=302)\end{array}$ & $\begin{array}{l}\text { Total } \\
(\mathrm{N}=606)\end{array}$ & \\
\hline \multicolumn{8}{|c|}{ Believe that the following is permitted by religion } \\
\hline FGM/C & $57(18.9)^{*}$ & $38(12.6)$ & $95(15.8)$ & $61(20.1)$ & $65(21.5)$ & $126(20.8)^{\dagger}$ & $221(18.3)$ \\
\hline Cutting wood in the forest & 96 (31.9) & $87(28.8)$ & $183(30.3)$ & $126(41.4)$ & $113(37.4)$ & $239(39.4)^{\dagger}$ & $422(34.9)$ \\
\hline $\begin{array}{r}\text { Paying police a bribe to avoid } \\
\text { trouble }\end{array}$ & $106(35.2)$ & $107(35.4)$ & $213(35.3)$ & $129(42.4)$ & $116(38.4)$ & $245(40.4)$ & 458 (37.9) \\
\hline \multicolumn{8}{|c|}{ Believe that the following is permitted by customs } \\
\hline FGM/C & $63(20.9)$ & $62(20.5)$ & $125(20.7)$ & $74(24.3)$ & $73(24.2)$ & $147(24.3)$ & $272(22.5)$ \\
\hline Cutting wood in the forest & $116(38.5)$ & 117 (38.7) & 233 (38.6) & $165(54.3)$ & $160(53.0)$ & $325(53.6)^{\dagger}$ & $558(46.2)$ \\
\hline $\begin{array}{r}\text { Paying police a bribe to avoid } \\
\text { trouble }\end{array}$ & 123 (40.9) & $126(41.7)$ & $249(41.3)$ & $152(50.0)$ & $148(49.0)$ & $300(49.5)^{\dagger}$ & $549(45.4)$ \\
\hline
\end{tabular}

Notes: + significant by country at $5 \%$ significance level; ${ }^{*}$ significant by gender at $5 \%$ significance level

About a fifth of all the respondents thought $\mathrm{FGM} / \mathrm{C}$ was permitted by their religion, while $35 \%$ and $38 \%$, respectively, thought cutting wood in the forest or paying the police a bribe to avoid trouble was permitted by their religion. There was a significant difference $(p=0.05)$ between the proportions of those who thought FGM/C was permitted by their religion in Burkina Faso (16\%) and Mali $(21 \%)$. A significant difference was also observed $(p<0.001)$ between the proportion of respondents who thought cutting wood was permitted by their religion in Burkina Faso (30\%) and Mali $(39 \%)$. There was, however, no significant difference $(p=0.197)$ between the proportion of those who thought paying the police a bribe to avoid trouble was permitted by their religion in Burkina Faso (35\%) and Mali (38\%). Nineteen percent of male respondents and $13 \%$ of female respondents $(p=0.013)$ in Burkina Faso, and $16 \%$ of male respondents and $20 \%$ of female respondents ( $p=0.007$ ) in Mali, thought FGM/C was permitted by their religion. Finally, there were no significant differences between Burkina Faso and Mali on the proportion of male and female respondents who thought cutting wood in the forest or paying the police a bribe to avoid trouble was permitted by their religion.

We also sought to understand whether respondent perceptions of whether the above-described activities were permitted by their religion differed from whether they believe FGM/C, cutting wood in the forest or paying the police a bribe to avoid trouble is permitted by their customs. Overall, compared to the religion responses discussed above, a similar pattern was observed in the proportion of respondents who thought FGM/C, cutting wood in the forest, or paying the police a bribe to avoid punishment was permitted by their customs. Twenty-three percent of all respondents thought $\mathrm{FGM} / \mathrm{C}$ was permitted by their customs. A relatively higher proportion of respondents said that cutting wood in the forest (46\%) and paying the police a bribe to avoid trouble $(45 \%)$ was permitted by their customs. When comparing the two countries, a higher proportion of respondents in Mali thought FGM/C was permitted by their customs (24\%) than among those in Burkina Faso (21\%), $\mathrm{p}=0.014$. A similar pattern was seen for respondents who thought cutting wood in the forest (Mali 54\%, Burkina Faso 39\%, $p<0.001$ ) and paying the police a bribe to avoid trouble (Mali $50 \%$, Burkina Faso $41 \%$, p=0.01) were permitted by their customs. There were, however, no significant differences observed in either country for all three activities when the results were disaggregated by gender (Table 12). 
Figure 10 shows respondents' perceptions of whether FGM/C is permitted by religion and customs by pair commune. In the graph, pair communes are arranged alongside each other. Faramana in Burkina Faso is compared to Koury in Mali, Koloko in Burkina Faso is compared to Finkolo in Mali, while Tansila in Burkina Faso is compared to Boura in Mali.

Figure 10: Proportion of respondents who believe FGM/C is permitted by their religion and customs

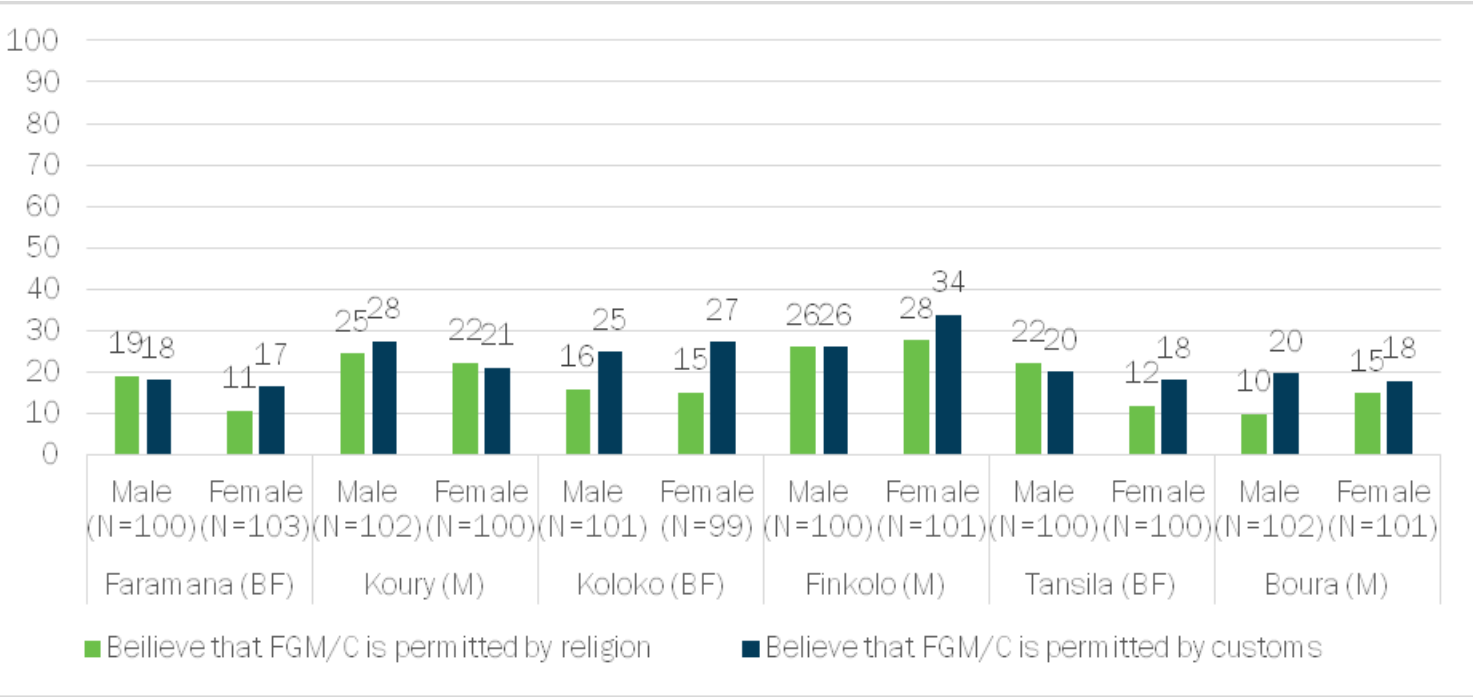

The data suggest that, in Faramana, a slightly higher proportion of female respondents (17\%) thought FGM/C was permitted by their customs, as compared to by their religion (11\%); and this difference is significant. In Koury, however, the proportion of female respondents who thought FGM/C was permitted by their religion (22\%) was not significantly different from those who said it was permitted by their customs (21\%). In Koloko, a higher proportion of both male (25\%) and female $(27 \%)$ respondents thought FGM/C was permitted by their customs, as compared to their religion (16\% male, $15 \%$ female). There was no significant difference between the proportion of male respondents who thought FGM/C was permitted by their religion and those who thought it was permitted by their customs. However, for women, a higher proportion of female respondents in Koloko (34\%) thought FGM/C was permitted by their customs, as compared to the $27 \%$ who thought it was permitted by their religion. In Tansila, a slightly higher proportion of male respondents (22\%) thought FGM/C was permitted by their religion, as compared to the $20 \%$ who thought it was permitted by their customs. A different scenario was observed among women, where $18 \%$, as compared to $12 \%$ of female respondents thought it was permitted by their customs and religion, respectively. In Boura, $20 \%$ of male respondents thought $\mathrm{FGM} / \mathrm{C}$ was permitted by their customs, while $10 \%$ thought it was permitted by their religion. Among female respondents, $18 \%$ thought it was permitted by their customs and $15 \%$ thought it was permitted by their religion.

\section{Reasons for practising FGM/C}

Table 13 shows why respondents thought FGM/C was practised in their respective communities. The results are disaggregated by country and by gender within each country. 
Table 13: Reasons for practise of FGM/C in Burkina Faso and Mali

\begin{tabular}{|c|c|c|c|c|c|c|c|}
\hline & \multicolumn{3}{|c|}{ Burkina Faso } & \multicolumn{3}{|l|}{ Mali } & \multirow[t]{2}{*}{$\begin{array}{l}\text { Total } \\
(\mathrm{N}=872)\end{array}$} \\
\hline & $\begin{array}{l}\text { Male } \\
(N=206)\end{array}$ & $\begin{array}{l}\text { Female } \\
(N=175)\end{array}$ & $\begin{array}{l}\text { Total } \\
(N=381)\end{array}$ & $\begin{array}{l}\text { Male } \\
(N=263)\end{array}$ & $\begin{array}{l}\text { Female } \\
(N=228)\end{array}$ & $\begin{array}{l}\text { Total } \\
(N=491)\end{array}$ & \\
\hline $\begin{array}{l}\text { Because everyone } \\
\text { else does it }\end{array}$ & $45(23.7)$ & 49 (29.5) & $94(26.4)$ & $51(21.5)$ & $56(27.7)$ & $107(24.4)$ & $201(25.3)$ \\
\hline $\begin{array}{l}\text { Religious } \\
\text { Obligation }\end{array}$ & $5(2.6)$ & $4(2.4)$ & $9(2.5)$ & $13(5.5)$ & $10(5.0)$ & $23(5.2)$ & $32(4.0)$ \\
\hline Tradition & $11(5.8)$ & $15(9.0)$ & $26(7.3)$ & $31(13.1)$ & $31(15.3)$ & $62(14.1) \dagger$ & $88(11.1)$ \\
\hline $\begin{array}{l}\text { Because there a } \\
\text { few arrests for } \\
\text { those who } \\
\text { practice }\end{array}$ & $48(25.3)$ & 27 (16.3) & 75 (21.1) & $43(18.1)$ & $29(14.4)$ & $72(16.4)$ & $147(18.5)$ \\
\hline Other & $78(41.1)$ & 59 (35.5) & $137(38.5)$ & $103(43.5)$ & $78(38.6)$ & $181(41.2)$ & $318(40.0)$ \\
\hline Don't know & $19(10.0)$ & $21(12.7)$ & $40(11.2)$ & $22(9.3)$ & $24(11.9)$ & $46(10.5)$ & $86(10.8)$ \\
\hline
\end{tabular}

A quarter of respondents (25\%) said they practised FGM/C because everyone else did it $(26 \%$ Burkina Faso, 24\% Mali, $p=0.512$ ), 4\% said it was a religious obligation (3\% Burkina Faso, 5\% Mali, $p=0.053$ ), $11 \%$ because of tradition (7\% Burkina Faso, 14\% Mali, $p=0.002$ ), and 19\% said they practised it because there were few arrests for those who did so (21\% Burkina Faso, $16 \%$ Mali, $p=0.092$ ). In Burkina Faso, $24 \%$ of male respondents and $29 \%$ of female respondents said they practised FGM/C because everyone else does it $(p=0.213)$, and similar proportions were also observed in Mali (22\% male, $28 \%$ female, $p=0.131)$. Significant differences by sex were observed among respondents who cited few arrests as the reason why they continued to practice FGM/C in Burkina Faso (25\% male vs. $16 \%$ female, $p=0.038$ ) while in Mali there were no significant difference by gender ( $14 \%$ male vs. $16 \%$ female, $p=0.286$ ).

We also compared the reasons given for practising FGM/C by those who said FGM/C was permitted by their religion against those who said it was permitted by their customs (Figure 11). In Burkina Faso, 46\% of respondents who thought FGM/C was permitted by their religion said they practised it because everyone else did it, as compared to a third (33\%) of those who thought it was permitted by their customs. There was no significant difference in Mali (27\%), however. Among those who thought FGM/C was permitted by their religion, as compared to those who thought $\mathrm{FGM} / \mathrm{C}$ was permitted by their customs, responses related to religious obligation, tradition, and few arrests did not differ significantly. 
Figure 11: Reasons for practising FGM/C among those thinking FGM/C was permitted by religion/custom

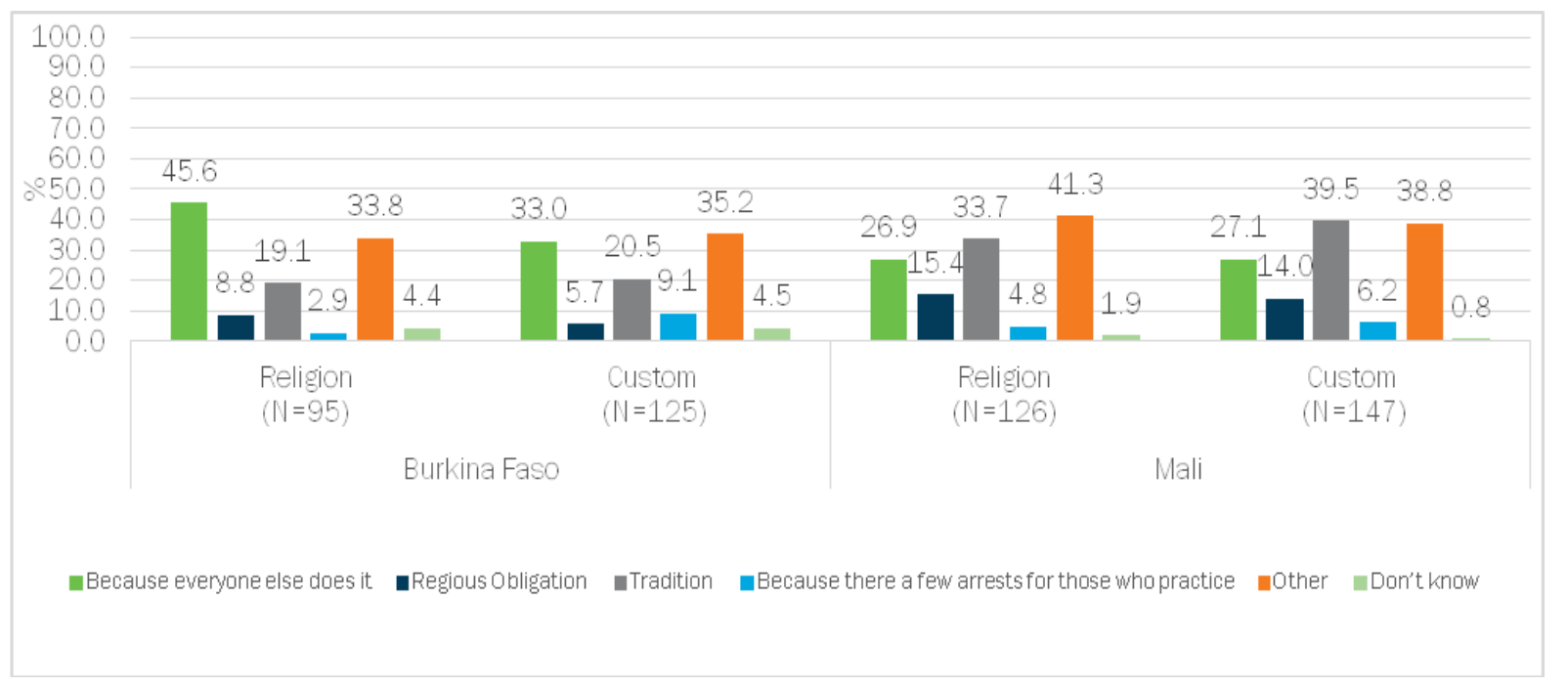

The qualitative results generally confirmed the quantitative data in this particular subject area. Interviewees linked the continuation of $\mathrm{FGM} / \mathrm{C}$ to their customs and religion. We asked our key informants and our FGD participants the reasons for having women and girls undergo $\mathrm{FGM} / \mathrm{C}$ in their community. Depending on the country, the ethnic groups and the experiences of the participants, a variety of reasons were invoked to justify the continuation of the practise. Culture/tradition, social reasons (such as marriageability), health reasons, pressure from elders, and sexuality were all listed.

Cultural reasons (or customs) were listed in both countries as one of the main justifications for the continued practise of FGM/C. Many respondents said they used to cut because it was their culture, their tradition, and that some continue to cut girls, even underground, because they still believe it is a part of their cultural practises and that these should be maintained. Regardless of gender, those who still support the practice are convinced that they are doing the right thing for their culture and that cutting has no disadvantages. The transcript excerpts below illustrate respondents' thinking on this issue.

"We were born to find this practise, so we do it until now and we haven't stopped it."

"For a very long time this has been done and there have been no disadvantages until now and we practise it without complications, which is why we do it."

Female, FGD 35+, Finkolo, Mali

"Since it is a practise of our ancestors, we only have to conform to it and perpetuate this tradition."

Male, FGD 18-34, Koury, Mali

Interestingly, only a few participants in Burkina Faso linked the practise of FGM/C to religion, and when they did, mainly to Islam. However, in Mali, participants said it is permitted and even requested by Islam, because Muslim women/girls must be pure. Given the fact that religious leaders have power in Mali, no politician dares to challenge their views by openly passing a law to ban the practise. The transcript excerpts below illustrate respondents' thinking on this subject.

"We would have liked to always have our girls cut because we were born and found that this practise had been around for a long time. Moreover, in the Muslim religion, FGM/C is an obligation."

Male, KII, Finnkolo, Mali 
Q: You just said that people would say nothing about a family who decided to cut their daughter?

"The prophet said, excuse me for the phrase, to cut so that the woman would not be hurt and there would be no consequences. The prophet says not to cut too much, you understand. We must not be ashamed to say things as they are. If I don't explain it this way, you won't have the answers to your questions. The prophet said to cut, but not to exceed a certain level."

Male, KII, Koury, Mali

In addition to religious reasons, respondents reported social reasons that led parents to cut their daughters. As they put it, belonging and being fully a woman within the community is only possible when one is cut. Participants explained that being cut is the ritual that allows a girl to become a woman and to enter the circle of women. So, an uncut woman, regardless of her age and whether she is married or not, is not mature and remains eternally a little girl. She has not grown up yet, so she cannot be fully a part of the community, and she cannot attend some women's activities that take place within her community. The only way to escape this pressure is when a husband is supportive of his wife's uncut status. The transcript excerpt below helps elucidate thinking on this issue.

"Well, if she is not cut and she is married it depends on how her husband understands it. Her husband may want this, or he may not want this. He can say that this one is not cut, so that she has not entered the field of women, she is still a girl. She is still a little girl, she's not a woman yet."

Male, KII, Finkolo, Mali

In the absence of a supportive husband, social pressure and isolation can foster suffering among uncut girls/women. To put an end to this situation, women sometimes ask to be cut in order to belong to the community. Also, in some communities where the practise runs deep, uncut girls will have a hard time getting married. Men want or are expected to marry a cut woman, and those who are not will be marginalised, much like their female counterparts. The transcript excerpts below illustrate how important social marginalisation is to the continuation of the practise.

What will people say about a girl who grew up without being cut?

"People will say it's not good and they will start criticising her parents."

"People will show contempt for her and start criticising her negatively. Moreover, it will be difficult for this girl to have a husband because men will sabotage her."

Male, FGD 18-34, Koury, Mali

"Those who oppose this practise will say that it is very good, but those who are in favour will feel betrayed and will hardly accept to marry the daughters of this family and by ricochet to give their daughter in marriage to the family who refuses to cut its girls."

Female, FGD, Finnkolo, Mali

"In our area for example, there is a fetish and when the girl is not cut, she is considered a child, regardless of her age. During the various rituals, the uncut girl cannot take part because she is considered a little girl."

Male, FGD 18-34, Koury, Mali 
In addition to the social reasons for continuing FGM/C, control of women's sexuality was also a recurrent theme in the narratives of the qualitative research participants. People used to believe, and some still do, that cutting functions to "make girls/women stay quiet." Many still believe that a cut woman has less sexual desire and will not cheat on her husband.

"A girl who is not cut is very dizzy, but those who are cut are not."

Male, FGD 35+, Koury, Mali

"As a local responsible, some people come to us with arguments that support FGM/C: they stand up for FGM/C because of the fact that an uncut woman remains faithful even if her husband is away for one year. An uncut woman cannot be faithful even if her husband is absent for only one month."

Male, KII, Koloko, Burkina Faso

In addition, participants from our FGDs believe that health and maternity reasons lead some parents to continue cutting their daughters. Some people believe that if a girl is not cut, she cannot give birth; and that she will have health issues. Some even believe that an uncut woman or girl can be a source of health problems to her partner or husband. Though some FGD participants said this is not proven to be true today, there are people in their communities who strongly believe that cutting has many health advantages.

Other participants linked decreases in cutting to early pregnancies experienced by girls today. They even see the campaign against FGM/C to be the main cause of the current early pregnancy situation. Given that they have stopped cutting girls, some believe that uncut girls like more sex and have sexual intercourse at an earlier age, hence the early pregnancies. They then justify early marriage by saying that abandonment of cutting forces them to make different marital choices. However, some participants also contradict this sexual control argument, arguing that nowadays they see cut and uncut girls equally "turning around men." Therefore, early pregnancy has more to do with the education the parents give to their daughters than being cut or not cut per se. Awareness of the consequences of FGM/C has led some parents to openly oppose $\mathrm{FGM} / \mathrm{C}$ in their communities so that their daughters are not cut. However, the social pressure remains so strong that many years of efforts to protect girls can vanish when a grown woman asks to be cut herself, as explained below.

"Personally, none of my four daughters have been cut. For this reason, my mother-in-law spent all her time insulting me and telling me that I had taken over the children. One of them was about to get married, and she was so influenced that she finally told me that she had to go and have herself cut. I replied by telling her that there was no way and that if she did it, I was no longer her mother. We fought; fought; and the year before last year, the cutter who spent many years without coming, came to the village and swept away all these years of effort because some girls who went on their own to have themselves cut were flattered, yet they were married and already had children. Girls that their parents did not cut went on their own to do it. "

Female, FGD 35+, Boura, Mali

\section{Behaviours/actions in face of FGM/C}

Respondents were asked what they would do if they learned that a neighbour was going to practise $\mathrm{FGM} / \mathrm{C}$. Table 13 presents overall proportions and disaggregated by country and by gender. 
Table 13: What would you do if you found out a neighbour was going to practise female genital mutilation/cutting

\begin{tabular}{|c|c|c|c|c|c|c|c|}
\hline & \multicolumn{3}{|c|}{ Burkina Faso } & \multicolumn{3}{|c|}{ Mali } & \multirow[t]{2}{*}{$\begin{array}{l}\text { Total } \\
(\mathrm{N}=1209)\end{array}$} \\
\hline & $\begin{array}{l}\text { Male } \\
(N=301)\end{array}$ & $\begin{array}{l}\text { Female } \\
(N=302)\end{array}$ & $\begin{array}{l}\text { Total } \\
(N=603)\end{array}$ & $\begin{array}{l}\text { Male } \\
(N=304)\end{array}$ & $\begin{array}{l}\text { Female } \\
(N=303)\end{array}$ & $\begin{array}{l}\text { Total } \\
(N=606)\end{array}$ & \\
\hline Nothing & $114(37.9)$ & $112(37.1)$ & $226(37.5)$ & $103(33.9)$ & $119(39.4)$ & $222(36.6)$ & $448(37.1)$ \\
\hline $\begin{array}{l}\text { Call telephone line } \\
\text { (hotline) }\end{array}$ & $3(1.0)$ & $2(0.7)$ & $5(0.8)$ & $6(2.0)$ & $3(1.0)$ & $9(1.5)$ & $14(1.2)$ \\
\hline $\begin{array}{l}\text { Tell the } \\
\text { police/gendarme }\end{array}$ & $36(12.0)$ & $43(14.2)$ & $79(13.1) \dagger$ & $26(8.6)$ & $17(5.6)$ & $43(7.1)$ & $122(10.1)$ \\
\hline Tell a social worker & $10(3.3)$ & $3(1.0)$ & $13(2.2)$ & $4(1.3)$ & $8(2.6)$ & $12(2.0)$ & $25(2.1)$ \\
\hline $\begin{array}{l}\text { Tell local } \\
\text { authorities }\end{array}$ & $25(8.3)$ & $17(5.6)$ & $42(7.0)$ & $34(11.2)$ & $26(8.6)$ & $60(9.9)$ & $102(8.4)$ \\
\hline $\begin{array}{l}\text { Tell a health } \\
\text { worker }\end{array}$ & $5(1.7)$ & $4(1.3)$ & $9(1.5)$ & $2(0.7)$ & $4(1.3)$ & $6(1.0)$ & $15(1.2)$ \\
\hline Tell a local NGO & $1(0.3)$ & $1(0.3)$ & $2(0.3)$ & $0(0.0)$ & $0(0.0)$ & $0(0.0)$ & $2(0.2)$ \\
\hline $\begin{array}{l}\text { Talk to a family } \\
\text { member }\end{array}$ & $63(20.9)$ & 77 (25.5) & $140(23.2)$ & $61(20.1)$ & $78(25.8)$ & $139(22.9)$ & $279(23.1)$ \\
\hline Do something else & $70(23.3)$ & $53(17.6)$ & $123(20.4)$ & $82(27.0)$ & $49(16.2)$ & $131(21.6)$ & $254(21.0)$ \\
\hline Don't know & $9(3.0)$ & $16(5.3)$ & $25(4.1)$ & $8(2.6)$ & $17(5.6)$ & $25(4.1)$ & $50(4.1)$ \\
\hline
\end{tabular}

Overall, $37 \%$ of all respondents said they would do nothing, $23 \%$ said they would talk to a family member, $10 \%$ said they would talk to the police, and $8 \%$ said they would tell local authorities. A significant difference was observed among respondents who said they would talk to the police between respondents surveyed in Burkina Faso (13\%) and Mali $(7 \%), p=0.001$. No significant differences were observed between respondents who said they would do nothing (38\% Burkina Faso, 37\% Mali); talk to a family member (23\% Burkina Faso, $23 \%$ Mali); or tell local authorities (7\% Burkina Faso, 10\% Mali). In Both Burkina Faso and Mali, a relatively higher proportion of female respondents ( 25\%), as compared to male respondents ( $20 \%)$ would talk to a family member $(p=0.033)$. Details regarding how residents of particular pair commune behave in the face of FGM/C are presented in Appendix Table 12.

\section{FGM/C prevalence estimates: Perceptions of the number of girls cut in the community}

Respondents were also asked about their perceptions of how many girls have been cut in their communities and whether they had been cut themselves. Table 14 presents the overall proportions, as well as these proportions disaggregated by country and by gender. 
Table 14: How many girls in your community do you think have been cut?

\begin{tabular}{|c|c|c|c|c|c|c|c|}
\hline & \multicolumn{3}{|c|}{ Burkina Faso } & \multicolumn{3}{|l|}{ Mali } & \multirow[t]{3}{*}{$\begin{array}{l}\text { Total } \\
(\mathrm{N}=1209)\end{array}$} \\
\hline & \multirow{2}{*}{$\begin{array}{l}\text { Male } \\
(N=301)\end{array}$} & \multirow{2}{*}{\begin{tabular}{|l|} 
Female \\
$(\mathrm{N}=302)$
\end{tabular}} & \multirow{2}{*}{$\begin{array}{l}\text { Total } \\
(N=603)\end{array}$} & \multirow{2}{*}{\begin{tabular}{|l|} 
Male \\
$(\mathrm{N}=304)$
\end{tabular}} & \multirow{2}{*}{$\begin{array}{l}\text { Female } \\
(N=303)\end{array}$} & \multirow{2}{*}{$\begin{array}{l}\text { Total } \\
(N=606)\end{array}$} & \\
\hline & & & & & & & \\
\hline \multicolumn{8}{|c|}{ How many girls in your community have been circumcised? } \\
\hline Everyone/all girls & $24(8.0)$ & $23(7.6)$ & $47(7.8)$ & $39(12.8)$ & $41(13.6)$ & $\begin{array}{l}80 \\
(13.2) \dagger\end{array}$ & $\begin{array}{l}127 \\
(10.5)\end{array}$ \\
\hline Most people/girls & $50(16.6)$ & $48(15.9)$ & $98(16.3)$ & $56(18.4)$ & $54(17.9)$ & $\begin{array}{l}110 \\
(18.2)\end{array}$ & $\begin{array}{l}208 \\
(17.2)\end{array}$ \\
\hline Some people/girls & $43(14.3)$ & $47(15.6)$ & $90(14.9)$ & $59(19.4)$ & $42(13.9)$ & $\begin{array}{l}101 \\
(16.7)\end{array}$ & $\begin{array}{l}191 \\
(15.8)\end{array}$ \\
\hline A few people/girls & $83(27.6)$ * & $57(18.9)$ & $140(23.2)$ & $87(28.6) *$ & $54(17.9)$ & $\begin{array}{l}141 \\
(23.3)\end{array}$ & $\begin{array}{l}281 \\
(23.2)\end{array}$ \\
\hline No one/no girl & $72(23.9)$ & $99(32.8)$ * & $\begin{array}{l}171(28.4) \\
\dagger\end{array}$ & $44(14.5)$ & $81(26.8)^{*}$ & $\begin{array}{l}125 \\
(20.6)\end{array}$ & $\begin{array}{l}296 \\
(24.5)\end{array}$ \\
\hline Don't know & $29(9.6)$ & $28(9.3)$ & $57(9.5)$ & $19(6.3)$ & $30(9.9)$ & $49(8.1)$ & $106(8.8)$ \\
\hline \multicolumn{8}{|c|}{ Have you or anyone in your family been circumcised? } \\
\hline Yes & $89(29.6)$ & $86(28.5)$ & $175(29.0)$ & $107(35.2)$ & $113(37.4)$ & $\begin{array}{l}220 \\
(36.3) \dagger\end{array}$ & $\begin{array}{l}395 \\
(32.7)\end{array}$ \\
\hline No & $197(65.4)$ & $198(65.6)$ & $395(65.5)$ & $180(59.2)$ & $167(55.3)$ & $\begin{array}{l}347 \\
(57.3)\end{array}$ & $\begin{array}{l}742 \\
(61.4)\end{array}$ \\
\hline Don't know & $15(5.0)$ & $18(6.0)$ & $33(5.5)$ & $15(4.9)$ & $21(7.0)$ & $36(5.9)$ & $69(5.7)$ \\
\hline Refused to answer & $0(0.0)$ & $0(0.0)$ & $0(0.0)$ & $2(0.7)$ & $1(0.3)$ & $3(0.5)$ & $3(0.3)$ \\
\hline
\end{tabular}

Overall, $28 \%$ of respondents thought that all or most girls had been cut, $23 \%$ thought a few girls had been cut, and $25 \%$ thought no girl had been cut; an additional $9 \%$ did not know. By country, $28 \%$ of respondents from Burkina Faso, as compared to $21 \%$ of respondents from Mali $(p=0.002)$ thought that no girl had been cut in their communities and these proportions differed significantly between male and female respondents in each country. About a quarter (24\%) of male respondents compared to a third (33\%) of female respondents in Burkina Faso $(p=0.016)$, and $15 \%$ of male and $27 \%$ of female respondents in Mali $(p<0.001)$ thought that no girl had been cut in their respective communities.

When asked whether they or someone in their family had been cut, one-third (33\%) of all respondents (overall) said yes, with their numbers being 29\% in Burkina Faso and $36 \%$ in Mali, $p=0.007$. There was no significant difference in the proportions by sex in each country: $30 \%$ of male and $29 \%$ of female respondents in Burkina Faso and $35 \%$ of male and $37 \%$ of female respondents in Mali. These estimates, disaggregated by pair commune, are presented in Appendix Table 10.

\section{Knowledge of FGM/C practise as compared to other criminalised conduct}

Figures 12 and 13 present the overall proportion of respondents with knowledge of FGM/C in comparison with other criminalised conduct, such as paying the police a bribe to avoid trouble and cutting wood in the forest. The results are disaggregated by country and by gender. 
Figure 12: Familiarity with FGM/C compared to other criminalised conduct

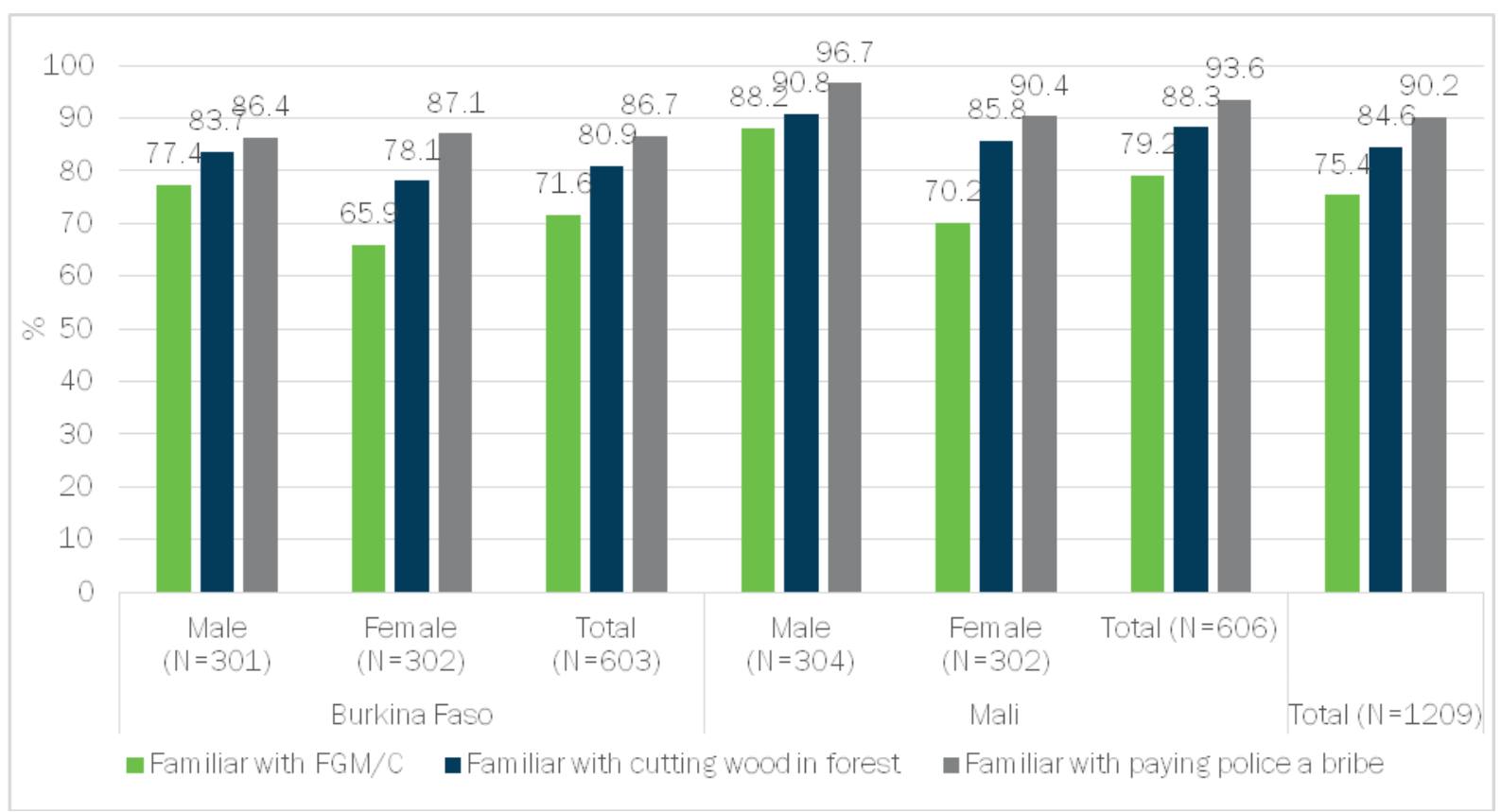

Overall, $75 \%$ of respondents were familiar with $\mathrm{FGM} / \mathrm{C}$ practise, with $85 \%$ and $90 \%$, respectively, saying they were familiar with cutting wood in the forest and paying the police a bribe to avoid trouble. The proportion of respondents who were familiar with $\mathrm{FGM} / \mathrm{C}$ practise was higher in Mali $(79 \%)$ than it was in Burkina Faso $(72 \%), p=0.002$, and in both countries the proportion of male respondents with knowledge was higher than that of female respondents (Burkina Faso: male $77 \%$, female $66 \%, p=0.002$; Mali: male $88 \%$, female $70 \%, p<0.001$ ). We also observed that the proportion of those who said they were familiar with FGM/C was significantly lower than those who said they were familiar with cutting wood in the forest as well as paying the police a bribe to avoid trouble. The difference margin between familiarity with $\mathrm{FGM} / \mathrm{C}$ and other criminal conduct was bigger among women in both Burkina Faso and Mali. More precisely, the difference margin between the proportion of female respondents in Burkina Faso who said they were familiar with cutting wood in the forest was $12.2 \%$, while for male respondents it was $6.2 \%$. In Mali, there was a similar pattern: the difference margin between the proportion of female respondents who said they were familiar with cutting wood in the forest was $15.3 \%$, as compared to male respondents (2.6\%). 
Figure 13: Perceptions on practise of FGM/C in the community compared to other criminalised conduct

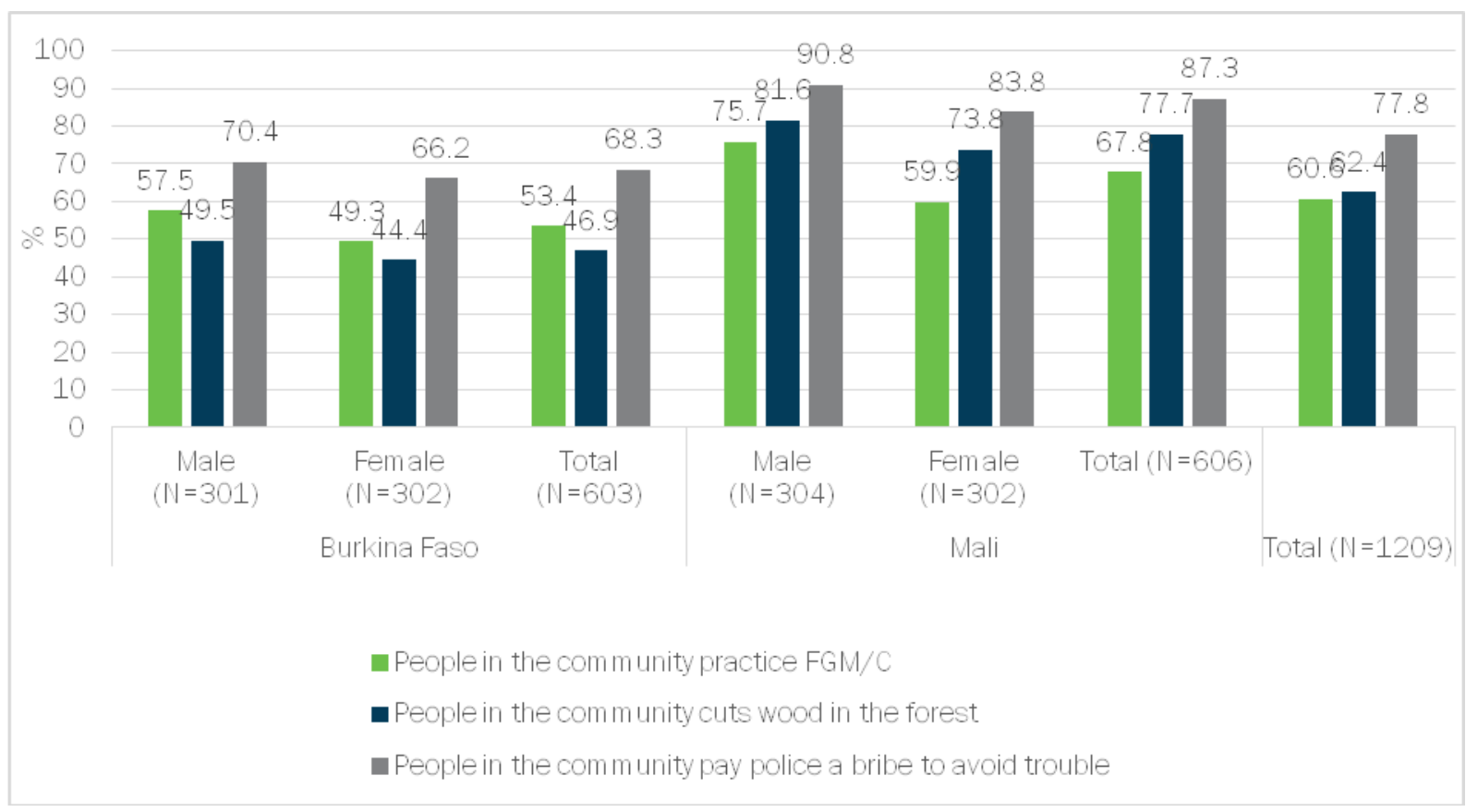

We also observed that $61 \%$ of all respondents (overall) thought that FGM/C was practised in their communities, while $62 \%$ and $78 \%$ thought cutting wood in the forest and paying the police a bribe to avoid trouble were practised. The proportions significantly differed by country. Approximately $53 \%$ of respondents in Burkina Faso and $68 \%$ of respondents in Mali $(p<0.001)$ thought $\mathrm{FGM} / \mathrm{C}$ was practised in their communities. Similar patterns were observed among respondents who thought that people in their communities cut wood in the forest (47\% Burkina Faso, $78 \%$ Mali, $p<0.001$ ) and paid the police bribes to avoid trouble $(68 \%$ Burkina Faso, $87 \%$ Mali, $\mathrm{p}<0.001$ ). In Mali, the proportion of respondents who thought that FGM/C was practised in their community was lower than that for both cutting wood in the forest $(78 \%)$ and paying the police a bribe to avoid trouble (87\%). Meanwhile, in Burkina Faso, the proportion of those who thought $\mathrm{FGM} / \mathrm{C}$ was practised in their community was slightly higher than that for cutting wood in the forest $(47 \%)$, but lower than that for paying the police a bribe to avoid trouble $(68 \%)$. The proportion of male respondents who thought $\mathrm{FGM} / \mathrm{C}$ was practised in their communities was higher than that of female respondents in both Burkina Faso (58\% male vs. $49 \%$ female, $\mathrm{p}=0.045)$ and Mali $(76 \%$ male vs. $60 \%$ female, $\mathrm{p}<0.001)$. A similar pattern is also seen in the proportion of those who thought people in their communities cut wood in the forest (Burkina Faso: $50 \%$ male, $44 \%$ female, $p=0.207$; Mali: $82 \%$ male, $74 \%$ female, $p=0.022$ ) and paid police a bribe to avoid trouble (Burkina Faso: $70 \%$ male, $66 \%$ female, $p=0.267$; Mali: $91 \%$ male, $84 \%$ female, $p=0.010$ ).

\section{Reasons for women and girls not undergoing FGM/C}

\section{Continuation/discontinuation of FGM/C}

Respondents were asked whether they thought FGM/C should continue or not, as well as whether they themselves planned to continue the practise even if everyone else in their communities was going to stop it. They were also asked their opinion on how much consideration they give to whether others practise FGM/C when deciding whether to do so themselves (Table 14 and Figure 15) 
Figure 14: Continuation of FGM/C among respondents even if everyone else in their community was to discontinue it

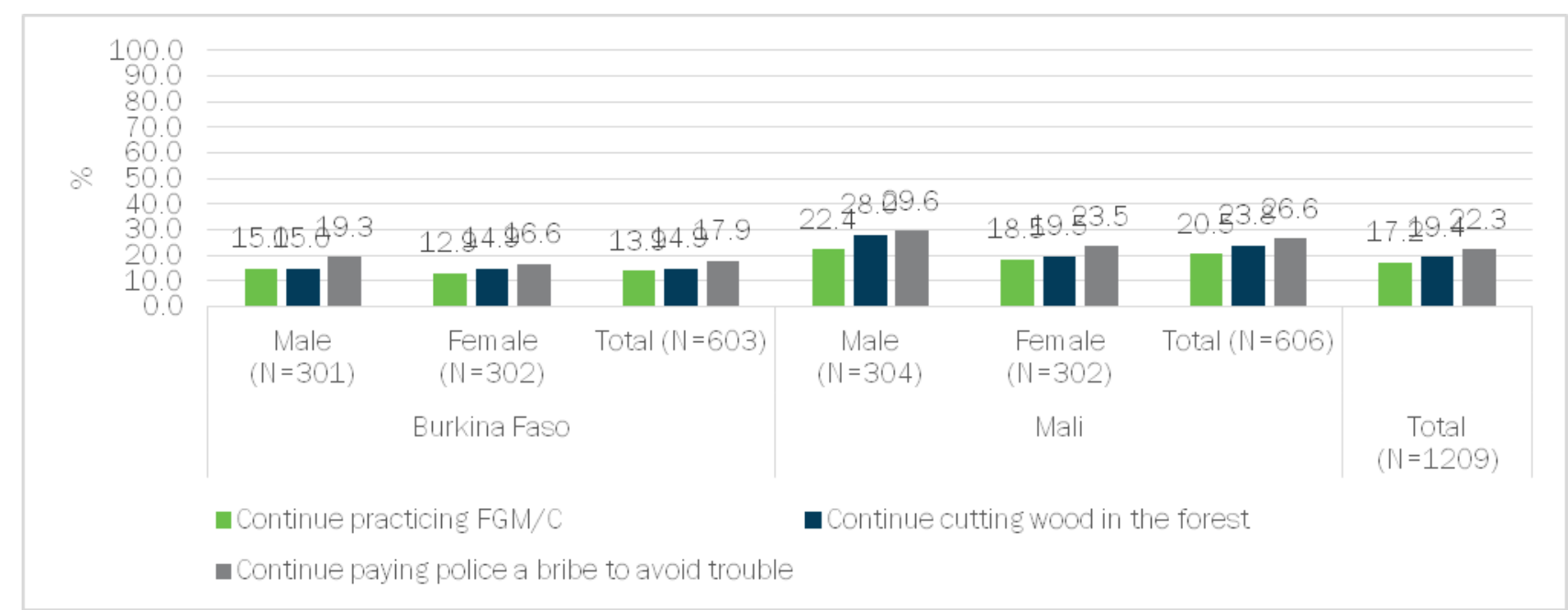

Overall, $17 \%$ of respondents stated that they would continue practising FGM/C even if everyone else in their community were to stop the practice (14\% Burkina Faso, $21 \%$ Mali, $p=0.003$ ). This was however slightly lower than those who said they would continue cutting wood in the forest $(19 \%)$ and paying the police bribes to avoid trouble (22\%). Disaggregated by gender within each country, $15 \%$ of male and $13 \%$ of female respondents in Burkina Faso $(p=0.470)$, as compared to $22 \%$ of male and $19 \%$ of female respondents in Mali $(p=0.243)$, said they would continue practising $\mathrm{FGM} / \mathrm{C}$ even if everyone else in their community were to stop it.

When asked whether they individually believed FGM/C should be stopped or should continue, $18 \%$ of respondents overall believed that the practice should continue (15\% Burkina Faso, $21 \%$ Mali, $p=0.005$ ) (Figure 14). This was slightly lower than those who believed cutting wood in the forest should continue (24\%) and paying the police bribes to avoid trouble (36\%). The proportions of those who believed these practises should continue were generally lower in Burkina Faso than in Mali. There was no significant difference in the proportions of those who believed FGM/C should continue by gender in both Burkina Faso (13\% male,16\% female, $\mathrm{p}=0.365$ ) and Mali ( $18 \%$ male, $23 \%$ female, $p=0.149$ ), though proportions of male were slightly lower. This confirms the work of Varol et al, (2015) showing generally greater support of abandonment among men in certain communities. For both male and female respondents in Burkina Faso, the proportions of those who believed FGM/C should continue was not significantly different from those who believed cutting wood in the forest should continue (male: $13 \%$ vs. $14 \%$; female: $16 \%$ vs. $15 \%$ ) but lower than paying the police bribes to avoid trouble (male: $13 \%$ vs. $28 \%$; female: $16 \%$ vs. $28 \%$ ) should continue. In Mali, however, the proportions of those who thought $\mathrm{FGM} / \mathrm{C}$ should continue was significantly lower than those who thought cutting wood in the forest (male: $18 \%$ vs. $33 \%$; female: $23 \%$ vs. $35 \%$ ) and paying the police bribes to avoid trouble (male: $18 \%$ vs. $41 \%$; female: $23 \%$ vs. $46 \%$ ) should continue. 
Figure 15: Proportions of those who believe FGM/C should continue in Burkina Faso and Mali

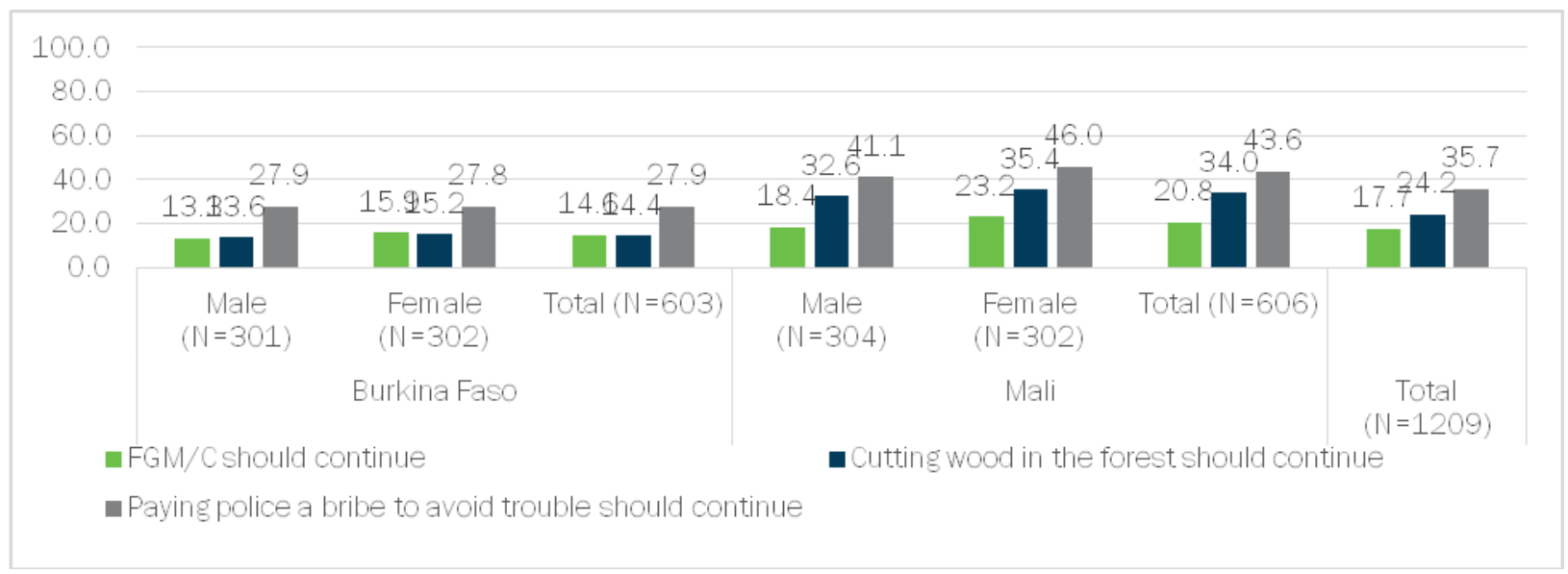

Table 15: Perceptions regarding the continuation/discontinuation of FGM/C in Burkina Faso and Mali

\begin{tabular}{|c|c|c|c|c|c|c|c|}
\hline & \multicolumn{3}{|c|}{ Burkina Faso } & \multicolumn{3}{|l|}{ Mali } & \multirow{2}{*}{$\begin{array}{l}\text { Total } \\
(\mathrm{N}=1209)\end{array}$} \\
\hline & $\begin{array}{l}\text { Male } \\
(N=301)\end{array}$ & $\begin{array}{l}\text { Female } \\
(N=302)\end{array}$ & $\begin{array}{l}\text { Total } \\
(N=603)\end{array}$ & $\begin{array}{l}\text { Male } \\
(N=304)\end{array}$ & $\begin{array}{l}\text { Female } \\
(N=302)\end{array}$ & $\begin{array}{l}\text { Total } \\
(N=606)\end{array}$ & \\
\hline \multicolumn{8}{|c|}{ If everyone else in your community were to stop FGM/C would you continue doing it? } \\
\hline Yes & $45(15.0)$ & $39(12.9)$ & 84 (13.9) & $68(22.4)$ & $56(18.5)$ & $\begin{array}{l}124 \\
(20.5) \dagger\end{array}$ & $208(17.2)$ \\
\hline No & $250(83.1)$ & $252(83.4)$ & $502(83.3)$ & $230(75.7)$ & $\begin{array}{l}234 \\
(77.5)\end{array}$ & $\begin{array}{l}464 \\
(76.6)\end{array}$ & $966(79.9)$ \\
\hline Don't know & $5(1.7)$ & $11(3.6)$ & $16(2.7)$ & $5(1.6)$ & $12(4.0)$ & $17(2.8)$ & $33(2.7)$ \\
\hline Refused to answer & $1(0.3)$ & $0(0.0)$ & $1(0.2)$ & $1(0.3)$ & $0(0.0)$ & $1(0.2)$ & $2(0.2)$ \\
\hline \multicolumn{8}{|c|}{$\begin{array}{l}\text { When deciding to practise FGM/C or not, how much consideration do you put to the question of whether } \\
\text { others practise it or not? }\end{array}$} \\
\hline Much consideration & $59(19.6)$ & $62(20.5)$ & $121(20.1)$ & $65(21.4)$ & $56(18.5)$ & $\begin{array}{l}121 \\
(20.0)\end{array}$ & $242(10.2)$ \\
\hline $\begin{array}{l}\text { Some } \\
\text { consideration }\end{array}$ & $72(23.9)$ & $74(24.5)$ & $146(24.2)$ & $69(22.7)$ & $69(22.8)$ & $\begin{array}{l}138 \\
(22.8)\end{array}$ & $284(23.5)$ \\
\hline $\begin{array}{l}\text { Not much } \\
\text { consideration }\end{array}$ & $52(17.3)$ & $53(17.5)$ & $105(17.4)$ & $49(16.1)$ & $43(14.2)$ & $92(15.2)$ & $197(16.3)$ \\
\hline No consideration & $100(33.2)$ & $84(27.8)$ & $184(30.5)$ & $103(33.9)$ & $\begin{array}{l}101 \\
(33.4)\end{array}$ & $\begin{array}{l}204 \\
(33.7)\end{array}$ & $388(32.1)$ \\
\hline Don't know & $18(6.0)$ & $29(9.6)$ & $47(7.8)$ & $18(5.9)$ & $\begin{array}{l}33 \\
(10.9)^{*}\end{array}$ & $51(8.4)$ & $98(8.1)$ \\
\hline \multicolumn{8}{|c|}{ Do your neighbours approve or disapprove if you practise FGM/C on your daughter in your household? } \\
\hline Strongly approve & $10(3.3)$ & $7(2.3)$ & $17(2.8)$ & $34(11.2)$ & $27(8.9)$ & $\begin{array}{l}61 \\
(10.1) \dagger\end{array}$ & $78(6.5)$ \\
\hline Approve & $79(26.2)$ & $72(23.8)$ & $151(25.0)$ & $78(25.7)$ & $87(28.8)$ & $\begin{array}{l}165 \\
(27.2)\end{array}$ & $316(26.1)$ \\
\hline Disapprove & $143(47.5)$ & $149(49.3)$ & $\begin{array}{l}292(48.4) \\
\dagger\end{array}$ & $122(40.1)$ & $\begin{array}{l}118 \\
(39.1)\end{array}$ & $\begin{array}{l}240 \\
(39.6)\end{array}$ & $532(44.0)$ \\
\hline
\end{tabular}




\begin{tabular}{|l|l|l|l|l|l|l|l|}
\hline $\begin{array}{l}\text { Strongly } \\
\text { disapprove }\end{array}$ & $59(19.6)$ & $53(17.5)$ & $112(18.6)$ & $60(19.7)$ & $49(16.2)$ & $\begin{array}{l}109 \\
(18.0)\end{array}$ & $221(18.3)$ \\
\hline Don't know & $10(3.3)$ & $21(7.0)^{*}$ & $31(5.1)$ & $10(3.3)$ & $21(7.0)^{*}$ & $31(5.1)$ & $62(5.1)$ \\
\hline Do you believe FGM/C should continue or should it be stopped? \\
\hline Continue & $40(13.3)$ & $48(15.9)$ & $88(14.6)$ & $56(18.4)$ & $70(23.2)$ & $\begin{array}{l}126 \\
(20.8) \dagger\end{array}$ & $214(17.7)$ \\
\hline Stopped & $258(85.7)$ & $245(81.1)$ & $503(83.4)$ & $245(80.6)$ & $\begin{array}{l}218 \\
(72.2)\end{array}$ & $\begin{array}{l}463 \\
(76.4)\end{array}$ & $966(79.9)$ \\
\hline Don't know & $3(1.0)$ & $8(2.6)$ & $11(1.8)$ & $3(1.0)$ & $13(4.3)$ & $16(2.6)$ & $27(2.2)$ \\
\hline Refused to answer & $0(0.0)$ & $1(0.3)$ & $1(0.2)$ & $0(0.0)$ & $1(0.3)$ & $1(0.2)$ & $2(0.2)$ \\
\hline Notes: $\dagger$ significant by country at $5 \%$ significance level; * significant by gender at 5\% significance level \\
\hline
\end{tabular}

Appendix Table 11 presents detailed results on the continuation/discontinuation rate of FGM/C disaggregated by pair commune and by gender.

\section{Awareness of the social costs of FGM/C}

When asked whether, in their opinion, life in the village was more difficult or less difficult for uncut women, $18 \%$ of respondents ( $16 \%$ Burkina Faso, $21 \%$ Mali, $p=0.041$ ) thought life is more difficult for uncut women. Disaggregated by gender, no significant differences were observed where $17 \%$ of male and $15 \%$ of female respondents from Burkina Faso, and $21 \%$ of male and $20 \%$ of female respondents from Mali thought life would be much more difficult for uncut women. On the other hand, $35 \%$ of all respondents (34\% Burkina Faso and $36 \%$ Mali, $p=0.434$ ) thought life would be much less difficult for uncut women in their communities. In both countries, the proportions of male and female respondents stating this response were not significantly different (Burkina Faso: $33 \%$ male vs. $34 \%$ female, $p=0.688$; Mali: $35 \%$ male vs. $37 \%$ female, $p=0.717$ ).

Table 16: Social costs of FGM/C for uncut women in Burkina Faso and Mali

\begin{tabular}{|c|c|c|c|c|c|c|c|}
\hline \multirow[b]{2}{*}{$\begin{array}{l}\text { Is life much more or less } \\
\text { difficult for the uncut } \\
\text { women? }\end{array}$} & \multicolumn{3}{|c|}{ Burkina Faso } & \multicolumn{3}{|l|}{ Mali } & \multirow[b]{2}{*}{$\begin{array}{l}\text { Total } \\
(\mathrm{N}=1209)\end{array}$} \\
\hline & $\begin{array}{l}\text { Male } \\
(N=301)\end{array}$ & $\begin{array}{l}\text { Female } \\
(N=302)\end{array}$ & $\begin{array}{l}\text { Total } \\
(N=603)\end{array}$ & $\begin{array}{l}\text { Male } \\
(N=304)\end{array}$ & $\begin{array}{l}\text { Female } \\
(N=302)\end{array}$ & $\begin{array}{l}\text { Total } \\
(N=606)\end{array}$ & \\
\hline Life is much more difficult & $52(17.3)$ & $44(14.6)$ & $96(15.9)$ & $65(21.4)$ & $59(19.5)$ & $\begin{array}{l}124 \\
(20.5) \dagger\end{array}$ & $\begin{array}{l}220 \\
(18.2)\end{array}$ \\
\hline Life is somewhat difficult & $38(12.6)$ & $52(17.2)$ & $90(14.9)$ & 40 (13.2) & $37(12.3)$ & $77(12.7)$ & $\begin{array}{l}167 \\
(13.8)\end{array}$ \\
\hline $\begin{array}{l}\text { Life is neither more or less } \\
\text { difficult }\end{array}$ & $59(19.6)$ & $46(15.2)$ & $105(17.4)$ & $45(14.8)$ & $50(16.6)$ & $95(15.7)$ & $\begin{array}{l}200 \\
(16.5)\end{array}$ \\
\hline Life is somewhat less difficult & $31(10.3)$ & $19(6.3)$ & $50(8.3)$ & $27(8.9)$ & $17(5.6)$ & $44(7.3)$ & $94(7.8)$ \\
\hline Life is much less difficult & 99 (32.9) & $104(34.4)$ & $203(33.7)$ & $111(36.5)$ & $\begin{array}{l}106 \\
(35.1)\end{array}$ & $\begin{array}{l}217 \\
(35.8)\end{array}$ & $\begin{array}{l}420 \\
(34.7)\end{array}$ \\
\hline Don't know & $22(7.3)$ & $36(11.9)$ & $58(9.6)$ & $16(5.3)$ & $\begin{array}{l}31 \\
(10.3)^{*}\end{array}$ & $47(7.8)$ & $105(8.7)$ \\
\hline Refused to answer & $0(0.0)$ & $1(0.3)$ & $1(0.2)$ & $0(0.0)$ & $2(0.7)$ & $2(0.3)$ & $3(0.3)$ \\
\hline
\end{tabular}

Appendix Table 12.includes detailed results, disaggregated by pair commune and by gender. 
This same topic was covered with qualitative participants (KII and FGD) by way of a vignette in which we asked them what would happen to a family that decided NOT to cut their daughter. We wanted to know what would happen to the uncut girl, and what would happen to the parents of the uncut girl. We also asked them why this family decided not to cut their daughter.

Responses to this vignette were illuminating. Among a number of other reasons that can lead a family to abandon cutting, the health consequences of cutting were a recurrent theme, from both key informants and FGD participants across all villages and in both countries. Respondents' knowledge of the health consequences of FGM/C seemingly came from the media (radio, TV), during the awareness-raising campaigns, but also from the lived experience of witnessing a cutting that turned out particularly poorly. Some people have seen the disadvantages of FGM/C for themselves and have learned that there are enormous risks to continuing the practice.

In addition to abandoning FGM/C for health reasons, some people have abandoned or said they would abandon FGM/C because they are sacred of legal consequences. This is particularly true in Burkina Faso, but also in Mali, despite the fact that there is no FGM/C law in place there. People in Mali are scared about the health consequences of FGM/C that may land them in jail (a huge hemorrhage or the death of the girl). The narratives below, from women FGDs participants, provide great summaries of the health consequences argument for abandoning the practice.

"I fully agree that we must abandon FGM/C. Our old lady [mother-in-law] insisted that my three daughters be cut. Long before we travelled to the cutter, she had talked about the two girls because my third daughter was always on my back. However, along the way, she changed her mind and told me that all three of my daughters must be cut. Once it was done, for the youngest one, it healed in less than a week. On the other hand, for the second one, we were very hot [hard time] because it bled so much that I didn't know which Saint to dedicate myself to; I regretted that so much and it took the intervention of a parent to stop the bleeding; he was the one who came to talk; we had to talk and finally we had to do what we didn't want to in order to stop the bleeding. Since that day, I am concerned, I no longer agree with FGM/C."

Female, 35+FGD, Boura, Mali

"I told you about the story of my daughter. It was SOPAL [local medication] that we used to have the bleeding stop. That day, we did everything, but we couldn't take her to the hospital. And when someone advised us to use SOPAL and we applied it, the blood stopped flowing."

Female, FGD 35+, Koury, Mali

"I have five daughters and it is only the elder who has not been able to escape FGM/C, otherwise the other four are not cut. People brag about this issue of FGM/C, but not everyone does it; there are some who have categorically refused to do so. I witnessed a case, and had it not been for my intervention, the girl was going to die. She could not be taken to the hospital because people were asked not to practise cutting anymore. So, after having cut the girl in question, at night her parents came to wake me up because the girl was constantly bleeding. I washed the wound with saltwater and the blood stopped flowing. Around 3 a.m., the bleeding started again, and the parents came to call me again; I did the same thing, i.e., I washed the wound with saltwater. The night was also the same scenario and the child was at the end of her strength, yet she kept bleeding. I had to go to the Catholic mission to ask the priest for help. He gave me cotton, compress and Betadine because he thought someone had hurt himself. This allowed the blood flow to stop. We continued this way until the wound healed. Then I went back to give the rest to the priest, and he asked me what had happened, but I didn't tell him the truth. I figured the most important thing was that he had just saved a life. If I had told him the truth that day, he wasn't going to give me the medicine and the child would die because we didn't have time to hang out anymore." 
An essential part of the health consequences story is the impact of health workers on convincing some parents to abandon the practice or at least to say that they would do so. Female FGD participants regularly talked about the health workers who told them not to cut their daughters anymore because of the health consequences associated with the practice. Given that women are often the ones within the family who brings any unwell kids to a community health worker, women may be scared that health workers will find out about any continued practise of FGM/C during health visits. Health workers also take the opportunity during medical visits to talk and educate mothers about the consequences of FGM/C. The transcript excerpts below should help illustrate the importance of community health workers to FGM/C abandonment.

"We do not do it anymore because the doctors told us not to."

Male, KII, Faramana, Burkina Faso

"We followed what the health workers told us. I learned with the health workers who told us not to cut the girls anymore"

Female, KII, Faramana, Burkina Faso

"The government has even made a decision to put an end to FGM/C in all our health centres. I had to post it here in the centre; but if I make the posters, the wind will take them away. Otherwise it is forbidden and in case someone is caught in it, I don't know how it will happen; because they told you it is forbidden and you dare to do it; so if they take you, you will be punished, according to the laws in force."

Male, KII, Koury, Mali

\section{Consequences for the uncut girl}

Qualitative participants stated that there are two types of consequences for uncut girls. The positive one is that nothing will happen to her. She will be accepted in the community, she will get married, have children with no problem, and she will not suffer during childbirth. Indeed, unless a woman's husband speaks about it openly, no one will know that she is uncut. Participants who were more against FGM/C in Burkina Faso and Mali were more likely to say that nothing will happen to an uncut woman or girl. In Burkina Faso, where the law bans FGM/C and where people are only cutting underground, respondents refused to say anything negative about uncut girls. Even in Mali, which has no FGM/C law, people are scared that cutting may turn out badly, thus, no one would say anything negative about the consequences for uncut women and girls. Instead they said some people would even congratulate the family who decides not to cut its girls.

"Nothing will happen to the uncut girls in our community. I personally know girls in the situation who got married, who have not suffered anything, and who have even had children; absolutely nothing will happen to them."

Female, KII, Faramana, Burkina Faso

Despite these progressive attitudes among some, other participants reported that people in communities that still believe FGM/C is a good thing will see an uncut girl differently. She can face mockery from others and people may fear approaching her. An uncut girl will also face problems when it comes time for her to get married. If she marries in a community where $\mathrm{FGM} / \mathrm{C}$ is practised, she may be marginalised. It is even possible that no man in the community would like to marry her. Importantly, all of these perceptions of uncut girls are linked to the perceived 
benefits of the cutting. In Mali, the uncut girl is called a blakoro [someone who is immature, impure], a negative word that shows that an uncut girl is not like other pure women.

"The girl is considered as it is said in Bambara language a "blakoro' [an uncut woman], she is not a perfect woman."

Male, KII, Koury, Mali

"I know that it is at the weddings that people often say that this girl is not cut. It seems that there are even girls who have even been sent back to their parents because they were not cut. I haven't seen these cases, but l've heard a lot about them. This means that for many parents, it is what pushes them to cut their daughters. They do not want her husband one day to repudiate her because she is not cut".

Male, KII Health, Faramana, Burkina Faso

\section{Consequences for the uncut girl's parents}

When respondents were asked what would happen to parents who refused to cut their daughters, qualitative responses were also divided. Most participants responded that nothing would happen to them because everyone knows that $\mathrm{FGM} / \mathrm{C}$ has many disadvantages and is illegal. Such attitudes prevail, even in Mali, where FGM/C per se is not illegal. However, others believe that they will face social isolation and marginalisation because they will have betrayed their community rules by failing to practise FGM/C. Being ostracised or socially dead in such communities can cause psychosocial trauma. The below transcript excerpt shows how some respondents view the social isolation that can result from $\mathrm{FGM} / \mathrm{C}$ abandonment.

"I think that socially the family will be indexed. Well, actually that's the main thing I see, since you belong to a community that has its laws. When you challenge these laws, it's like you're getting out of the community. So that's what it's all about, this isolation, your way of seeing things that makes you leave the community. You have refused to respect the rules on a customary level and that is what can put you aside, that is what I see."

Male, KII, Tansila, Burkina Faso

The duelling perceptions of the consequences of FGM/C abandonment for uncut girls and their parents confirm that there has been a positive shift in perceptions and behaviours. However, it also shows there is some resistance that supports FGM/C as a social norm (Mackie 2017; Cislaghi and Heise 2017) under which one is expected to conform to what others do and expect you to do. The social rejection and the shame associated with not conforming to what the majority do, or are perceived to do, can force an individual to conform, even relatively unwillingly, to a practise that they may not agree with.

\section{Discussion}

As with previous studies (Diop et al., 2008; GRIGED 2008; UNFPA 2016; CNLPE 2016a, 2016b; Crisman et al. 2016), we find that FGM/C in our study communities is still strongly linked to cultural, societal, and religious beliefs that demand that women and girls undergo the practise. This perception can lead to the stigmatisation and isolation of uncut girls and their parents, particularly in communities in Mali, where adult women ask to be cut in order to lessen the social pressure.

While FGM/C persists in both Burkina Faso and Mali, the government of Burkina Faso has taken measures to curb and eradicate the practise. The government of Mali, in contrast, has not passed a law that specifically criminalises FGM/C. Many draft laws have received "continued 
objections, particularly from high-profile religious leaders who support the practise" (28TooMany 2018). However, the Malian government does have a strategy in put an end to FGM/C. In 2002 it established the National Programme for the Fight against Excision (Programme National de Lutte pour l'abandon de l'Excision) (PNLE); it also adopted a National Action Plan that addresses FGM/C for the period 2015-19. It is against this backdrop that our study was conducted in three pair villages along the Burkina Faso-Mali border. Its findings are revealing.

Perhaps the most interesting relates to legal knowledge, with $87 \%$ and $80 \%$ of respondents in Burkina Faso and Mali, respectively, thinking that FGM/C is illegal in their country. Burkina Faso's FGM/C law was also well known by our qualitative respondents and this is consistent with previous research conducted in Burkina Faso (CNLPE 2016a, 2016b; UNFPA 2016). Mali, however, has no such law. Despite this, many respondents in Mali seem to think that the practise is in fact illegal there. The number of people who report FGM/C to be illegal in Mali is lower than it is in Burkina, which suggests that the law appears to be working in Burkina, but we still need to explain why respondents in Mali are so wrong (in a good way) about FGM/C law in their own country.

We also found out that respect for the law was the main reason that motivated respondents individually to obey the law while they believed that fear of social sanctions motivated others to do so, and not fear of punishment in the first instance. Overall, $64 \%$ of respondents in both countries (67\% in Burkina Faso and $61 \%$ in Mali) believed people had an obligation to comply with a law prohibiting FGM/C. This moral obligation is a key motivation behind legal obedience. Our results also confirm what is already known: $F G M / C$ is a practise driven by social norms, which is the social expectations that members of a group hold of one another (Mackie et al. 2015). When asked whether they would pursue FGM/C if everyone in their community were to stop it, $83.3 \%$ and $76.6 \%$ of respondents in Burkina Faso and Mali, respectively, said they would stop the practise. This suggests that the fight against the practice should continue to focus on a variety of efforts at the community level and, particularly, ones that work through community leaders as key players reaching consensus on abandonment. The Mali-Burkina Faso comparison showed that law interacts with other motivations and with the ultimate decision to continue or stop FGM/C.

Legal pluralism (multiple legal authorities) was predominant, in terms of conflicts resolution as well as regulating people's behaviours. Statutory and customary law are sometimes in conflict, including on women's and girls' rights issues such as child marriage, FGM/C, and access to land for women. Interventions for FGM/C abandonment should recognise the fact of legal pluralism where it exists. Disobedience of FGM/C law in the context of legal pluralism was also a matter of allegiance to conflicting customary or religious authorities. Though FGM/C is the crux of this study, these findings have implications for other areas in plural legal contexts.

The relationship between child/early marriage and FGM/C is also an important, and somewhat expected finding from our qualitative data. Child/early marriage is a form of gender-based violence and is just as harmful a practise to girls as $\mathrm{FGM} / \mathrm{C}$, which was pointed out by many qualitative respondents.

"If you get married when you are still a child, you will suffer enormously: if you get pregnant, your delivery could be difficult [...]"

Female, FGD, Faramana, Burkina Faso.

Interestingly, qualitative FGD respondents from some communities in Burkina Faso (Faramana and Koloko) were keener to speak openly about child marriage (also illegal) and its manifestations than they were about FGM/C. This openness and close relationship between two 
harmful practises also suggest how Burkina Faso's FGM/C law has affected perceptions at the community level.

In addition, health workers seemed to have tremendous influence on women in our study communities. They are a respected source of knowledge regarding FGM/C prohibition and health consequences. Many female participants reported that they have stopped cutting their daughters because health workers told them to stop. Health workers also provide confidence to women who face social pressure to cut their daughters. Our findings suggest that health workers are agents of change and play an important role in the abandonment process. They should be receiving more support from their respective governments to continue to advise and advocate for the abandonment of $\mathrm{FGM} / \mathrm{C}$, not only among their female patients, but among all patients in the community, particularly as fear of health consequences is a key driver of FGM/C abandonment within these communities.

\section{Limitations}

Contamination: The study was designed to minimise possible contamination, i.e., participants from village A talking about the study to people from village $B$. This was accomplished by way of a minimum distance between each pair village of $30 \mathrm{~km}$. There may have been some contamination beyond our control, but we expect from our experience on the ground that this was minimal.

KII sample: We selected our key informants to obtain a diversity of roles and positions within each community with the goal of gathering diverse, in-depth information on our topics of interest. We interviewed the maximum number of key informants available, but we may not have reached saturation where the samples were relatively small (seven in Boura vs. 12 in Finkolo).

FGD sample: We recruited participants through community facilitators in each village to ensure diversity and inclusion. We asked them to assist our team leader to recruit participants widely. Our team leader was present during the whole process with participants, but we had no means to control whether participants with different points of view were excluded.

FGM/C law in Burkina Faso: Measures were taken to build trust with the study participants and to ensure they were at ease participating in the study; this included providing information on anonymity and confidentially of the data and random selection of quantitative survey participants. However, given that FGM/C is criminal in Burkina Faso and people do know of prosecutions, this may have hindered their responses. Our experience suggests that most participants felt little fear and were forthcoming, but this cannot be totally excluded as a source of data contamination.

Security situation: The data were collected in a very insecure environment, we may not have been able to reach as many participants as we would have liked. The cross-border methodology demanded that data collectors leave villages as quickly as possible. With more time, we may have been able to reach other participants who were absent, resulting in more diverse data.

The list experiment: The list experiment, which was designed to get around various respondent biases and to provide a more accurate estimate of planned future prevalence than possible using other methodological approaches, also has limitations. For instance, it is possible, despite the anonymity provided by the list experiment, that respondents will still seek to hide any intention of practising $\mathrm{FGM} / \mathrm{C}$. If this is true, the prevalence rates we find here would be underestimates. It is also possible that respondents might plan to practise $\mathrm{FGM} / \mathrm{C}$ in the future but fail to carry out these intentions due to a variety of intervening factors, including frustration of efforts by 
authorities. In this case, the prevalence rates we find would be overestimates. Unfortunately, there are few ways to reduce remaining limitations of the list experiment approach.

Researchers' triangulation: Given the impossibility of getting a sample of transcripts translated from French into English, the co-PI was unable to access the qualitative data and to largely contribute to the interpretation. To try to mitigate this, the team held regular meetings as the analysis progresses to discuss the emerging themes from the data in French.

\section{Conclusion}

The shift towards FGM/C abandonment is occurring in Burkina Faso. The list experiment results confirm this trend; there is a very clear cross-border difference for each of the village pairs, with higher reported rates of planned FGM/C in Mali than in Burkina Faso. This suggests that the law is working in Burkina Faso and that some combination of harsh enforcement and complementary implementation efforts have been beneficial. In Burkina Faso, participants have strong knowledge of FGM/C law, confirmed previous findings. The Mali results on legal knowledge (Koury $73 \%$, Finkolo $81 \%$, and Boura $83 \%$ ) believing that FGM/C is illegal) are unexpected and fascinating. This is important in terms of future efforts to pass an FGM/C law in Mali. Awareness of health consequences and the risk of a girl's death, in addition to respect for the law, drives some families to abandon the practise or at least say they will do so. Health workers and local leaders seemingly play a key role in the shift towards abandonment.

These above positive results are complicated by the persistence of attitudes, beliefs, and perceptions that $\mathrm{FGM} / \mathrm{C}$ still has many advantages. There are still many people who strongly support FGM/C, even in Burkina Faso, where projected prevalence is very low. Further research should explore the extent of this resistance, its motivations and causes, in order to discern the abandonment message that is best suited to the specific contexts of those people who have resisted all actions taken so far.

\section{Implications for Policy/Programmes/Research}

\section{Programmatic suggestions}

- Strengthen the role of health workers as agents of change in all interventions aiming to eliminate $\mathrm{FGM} / \mathrm{C}$ in both countries.

\section{Policy suggestions}

- Continue to pursue the sensitisation and awareness-raising efforts implemented by the government of Burkina Faso over the last 20 years. As part of this, the FGM/C law was translated into the three main local languages (Mooré, Dioula, and Fulfuldé) and communicated via local radio. This strategy may even be working beyond the border, as evidenced by the data on legal knowledge in Malian pair villages. The local language of all six pair villages is Dioula, which means that messages delivered via radio reach communities on both sides of the border.

- Implement and strengthen international coordination to eliminate cross-border FGM/C. Our results revealed that regional cooperation is necessary to curb FGM/C in the border area. Instead of passing a different law in Mali, a regional law that is effectively applied in both neighbouring countries would be an effective tool given the legal knowledge of Malian respondents indicated by our findings. A regional law that intensifies efforts at the 
community-level across the border should help to reduce the underground practise of crossborder FGM/C.

- Engage with local leaders to encourage abandonment. We find that customary law is strong in our study communities and that the village chief is primarily responsible for conflict resolution, though he often consults other key community members (imam, land chief) depending on the nature of the conflict. This means that approaches to end FGM/C will be more effective when powerful and influential leaders are on board. The government of Burkina Faso has experience implementing FGM/C law through community leaders, where village chiefs, imams, and other influential people are involved in all community interventions.

- Develop strategies, particularly in Mali, to convince religious leaders (who have tremendous influence) to ask followers to stop pursuing the practise.

- Experiment interventions using acceptable alternatives to $\mathrm{FGM} / \mathrm{C}$, such as other harmless rites of passage to replace $\mathrm{FGM} / \mathrm{C}$ in areas where there has been resistance to all actions undertaken to date combat the practise.

\section{Research Suggestions}

- Conduct research to better understand the source of knowledge for people in Mali who think that $\mathrm{FGM} / \mathrm{C}$ is illegal in their country and to better understand the dissonance between individual/local acceptance of the behaviour and attitudes that FGM/C is nationally unacceptable. Future efforts should investigate any and all factors explaining why the practise persists despite acknowledgement of the unacceptability and the illegality of the practise.

- Scale up cross-border research to include other countries neighbouring Burkina Faso that have an FGM/C a law (Côte d'Ivoire, Ghana, Niger) and where Burkinabe families also cross the border to have their daughters undergo the practice (GRIGED 2008; UNFPA 2016). Replicate the list experiment to assess the effect or contribution of the law and strengthen the findings. This methodology can easily be applied to other countries that want to assess the cross-border effects of their law.

- Despite a shift to FGM/C abandonment in Burkina Faso, there are still some families that continue to practise FGM/C and plan to do so in the future. They are strong supporters of the practice and their attitudes, behaviours, and perceptions are linked to the advantages of the practice, as well as cultural and social reasons. Underground continuation of the practise, such as cross-border FGM/C, cutting girls at young age, and cutting during the rainy season, is therefore not surprising. Medicalisation is also occurring in some settings. A sound anthropological study involving the community-level immersion of involved researchers may help to provide in-depth knowledge about how to persuade deep supporters of FGM/C to abandon the practise. The design of this study could be informed by lessons learned in other settings where increased abandonment has taken place. 


\section{References}

28TooMany. 2018. "Mali: The law and FGM." Report. London: 28TooMany.

Aldashev, G., Chaara, I., Platteau, J. P., and Wahhaj, Z. (2012). Formal law as a magnet to reform custom. Economic Development and Cultural Change, 60(4), 795-828.

Berer, M. 2015. The history and role of the criminal law in anti-FGM campaigns: Is the criminal law what is needed, at least in countries like Great Britain?. Reproductive health matters, 23(46), 145-157.

Boyden, J., Pankhurst, A., and Tafere, Y. 2013. Harmful traditional practices and child protection: contested understandings and practices of female child marriage and circumcision in Ethiopia. Young Lives.

Boyes-Watson, C. 2014. "What is restorative justice?" Boston: Suffolk University. http://www.suffolk.edu/college/centers/15970.php

Cislaghi, B. and L. Heise. 2017. STRIVE Technical Brief: Measuring Social Norms. London: London School of Hygiene and Tropical Medicine.

CNLPE (National Committee to Fight the practice of Excision). 2016a. Évaluation de l'impact des activités de promotion de l'élimination de la pratique de l'excision de 1990 à 2015 au Burkina Faso, Final Report. Ouagadougou : Ministry of Family, National Solidarity and Women.

2016b. Plan stratégique national de promotion de l'élimination des mutilations génitales féminines au Burkina Faso (PSN/MGF) 2016-2020. Ouagadougou : Ministry of Family, National Solidarity and Women.

Crisman, B., S. Dykstra, C. Keny, and M. O'Donnell. 2016. “The Impact of Legislation on the Hazard of Female Genital Mutilation/Cutting: Regression Discontinuity Evidence from Burkina Faso," Working Paper 432. Washington, DC: Center for Global Development. Available at: https://www.cgdev.org/publication/impact-legislation-hazard-female-genitalmutilationcutting-regression-discontinuity

Diop, N.J., Z. Congo, A. Ouédraogo, A. Sawadogo, L. Saloucou, and I. Tamini. 2008. "Analysis of the evolution of the practise of female genital mutilation/cutting in Burkina Faso," FRONTIERS Final Report. Washington, DC: Population Council.

Engelsma, B., G. Mackie, and B. Merrell. 2018. "Unprogrammed abandonment of female genital mutilation/cutting." Evidence to End FGM/C: Research to Help Women Thrive. New York: Population Council.

Feldman, Y. (2011). The complexity of disentangling intrinsic and extrinsic compliance motivations: Theoretical and empirical insights from the behavioral analysis of law. Wash. UJL \& Pol'y, 35, 11.

Friedman, L.M. 2016. Impact: How Law Affects Behavior. Cambridge, MA: Harvard University Press.

Griffiths, J. 1986. "What is legal pluralism,” Journal of Legal Pluralism 24: 1-55.

GRIGED. 2008. Pratique transfrontalière de l'excision: Etat des lieux et évaluation des actions dans les zones frontalières du Burkina Faso, de la Côte d'Ivoire, du Ghana, du Mali et du Niger.

Hafner-Burton, E. M., Victor, D. G., and Lupu, Y. 2012. Political science research on international law: the state of the field. American Journal of International Law, 106(1), 47-97.

Hathaway, O. A. 2007. Why do countries commit to human rights treaties?. Journal of Conflict Resolution, 51(4), 588-621.

Herbert, H., and Hart, A. (1961). The concept of law. The Mythology of Modern Law, 3. 
INFO-Stat/Mali and ICF International. 2014. Enquête démographique et de santé au Mali 20122013. Rockville MD: CPS, INSTAT, INFO-STATE, and ICF International.

Institut National de la Statistique et de la Démographie (INSD), Ministère de l'Économie et des Finances, Burkina Faso. 2012. Enquête Démographique et de Santé et à Indicateurs Multiples (EDSBF-MICS IV) 2010. Calverton, MD: ICF International. Bank.

2015. Enquête Multisectorielle Continue. The World Bank Microdata Library. Geneva: World

Kahan, D.M. 1997. "Social influence, social meaning, and deterrence," Virginia Law Review 83(2): 349-395.

Mackie, G. 2017. "Effective rule of law requires construction of a social norm of legal obedience," in C. Tognato (ed.), Cultural Agents Reloaded: The Legacy of Antanas Mockus. Cambridge, MA: Harvard University Press.

Mackie, G., F. Moneti, H. Shakya, and E. Denny. 2015. What Are Social Norms? How Are They Measured? New York and San Diego: UNICEF/University of California, San Diego, Center on Global Justice.

McAdams, R.H. 2015. The Expressive Powers of Law: Theories and Limits. Cambridge, MA: Harvard University Press.

Ministry of Justice, Human Rights and Civil Promotion. 2018. "Code pénal." Ouagadougou: Burkina Faso

Mockus, A. 2002. "Co-existence as harmonization of law, morality, and culture," Prospects 32(1): 19-37.

Nagin, D. S., and Pogarsky, G. 2001. Integrating celerity, impulsivity, and extralegal sanction threats into a model of general deterrence: Theory and evidence. Criminology, 39(4), 865-892.

Neumayer, E. 2005. Do international human rights treaties improve respect for human rights?. Journal of conflict resolution, 49(6), 925-953.

Nussbaum, M.C. 1999. "Judging other cultures: The case of genital mutilation," in M.C. Nussbaum (ed.), Sex and Social Justice, pp. 118-129. Oxford: Oxford University Press.

Platteau, J. P. 2010. Redistributive pressures in sub-Saharan africa: Causes, consequences, and coping strategies. Conference'Understanding African Poverty in the Longue Durée'. International Institute for the Advanced Study of Cultures, Institutions, and Economic Enterprise (IIAS), Accra, July, 15-17.

Pratt, T. C., Cullen, F. T., Blevins, K. R., Daigle, L. E., and Madensen, T. D. 2006. The Empirical Status of Deterrence Theory: A Meta-Analysis.

Ramey, V., N. Sangaré, D. Damianova. 2019. Média, Accès à l'Information et aux TIC, et Émancipation des Femmes et des Filles. Ouagadougou: European Union Office of Burkina Faso.

Secrétariat du gouvernement. 2002. Code pénal 2001 CODE PENAL LOI N 01-079 DU 20 AOUT 2001. Bamako: Republic of Mali.

Shahvisi, A. and B.D. Earp. 2019. "The law and ethics of female genital cutting," in S. Creighton and L.-M. Liao (eds.), Female Genital Cosmetic Surgery: Solution to What Problem? pp. 58-71. Cambridge: Cambridge University Press.

Shell-Duncan, B., Herlund, Y., Moreau, A., and Lauron-Moreau, A. 2013. Legislating change? Responses to criminalizing female genital cutting in Senegal. Sex and Social Justice.

Sherman, L. W. 1993. Defiance, deterrence, and irrelevance: A theory of the criminal sanction. Journal of research in Crime and Delinquency, 30(4), 445-473. 
Stavenhagen, R., and Iturralde, D. A. 1990. Entre la ley y la costumbre: el derecho consuetudinario indígena en América Latina. Instituto Interamericano de Derechos Humanos. Instituto Indigenista Interamericano..

Tamanaha, B. Z. (2008). Understanding legal pluralism: past to present, local to global. Sydney L. Rev., 30, 375.

Tamanaha, B. Z., Sage, C., and Woolcock, M. (Eds.). 2012. Legal pluralism and development: Scholars and practitioners in dialogue. Cambridge University Press.

Tyler, T.R. 1990. Why People Obey the Law. Princeton, NJ: Princeton University Press.

UNICEF. 2010. Legislative Reform to Support the Abandonment of Female Genital Cutting. New York: UNICEF

2013. Female Genital Mutilation/Cutting: A Statistical Overview and Exploration of the Dynamics of Change. New York: UNICEF.

2016. Female Genital Mutilation/Cutting: A Global Concern. UNICEF global databases 2016 based on DHS, MICS and other nationally representative surveys, 2004-2015. New York: UNICEF.

UNFPA. 2016. Étude frontalière sur les pratiques transfrontalières des Mutilations Génitales Féminines (MGF). Rapport d'enquête. Ougadougou: UNFPA Burkina Faso. . 2018. Analysis of Legal Frameworks on Female Genital Mutilation in Selected Countries in West Africa. Dakar: UNFPA Regional Office for West and Central Africa.

UNFPA-UNICEF Joint Programme. 2015. Metrics of Progress, Moments of Change. Annual Report. New York : UNFPA-UNICEF Joint Programme.

Varol, N., S. Turkmani, K. Black, J. Hall, and A. Dawson. 2015. "The role of men in abandonment of female genital mutilation: A systematic review," BMC Public Health 15(1): 1034.

World Health Organization. 2000. Health Complications of Female Genital Mutilation Including Sequelae in Childbirth. Geneva: WHO.

World Health Organization, United Nations Population Fund (UNFPA) and United Nations Children's Fund (UNICEF). 1997. "Female genital mutilation: A joint WHO/UNICEF/UNFPA statement." Geneva: World Health Organization. Available at: https://apps.who.int/iris/handle/10665/41903. 


\section{Appendices}

Table 1: Types of disputes and conflict resolution mechanisms

\begin{tabular}{|c|c|c|c|c|c|c|c|c|c|c|c|c|}
\hline & \multicolumn{2}{|c|}{ Faramana } & \multicolumn{2}{|l|}{ Koury } & \multicolumn{2}{|l|}{ Koloko } & \multicolumn{2}{|l|}{ Finkolo } & \multicolumn{2}{|l|}{ Tansila } & \multicolumn{2}{|l|}{ Boura } \\
\hline & $\begin{array}{l}\text { Male } \\
(\mathrm{N}=100)\end{array}$ & $\begin{array}{l}\text { Female } \\
(\mathrm{N}=103)\end{array}$ & $\begin{array}{l}\text { Male } \\
(\mathrm{N}=102)\end{array}$ & $\begin{array}{l}\text { Female } \\
(\mathrm{N}=100)\end{array}$ & $\begin{array}{l}\text { Male } \\
(\mathrm{N}=101)\end{array}$ & \begin{tabular}{|l|} 
Female \\
$(\mathrm{N}=99)$
\end{tabular} & $\begin{array}{l}\text { Male } \\
(\mathrm{N}=100)\end{array}$ & $\begin{array}{l}\text { Female } \\
\text { (101) }\end{array}$ & $\begin{array}{l}\text { Male } \\
(\mathrm{N}=100)\end{array}$ & $\begin{array}{l}\text { Female } \\
(\mathrm{N}=100)\end{array}$ & \begin{tabular}{|l|} 
Male \\
$(\mathrm{N}=102)$
\end{tabular} & $\begin{array}{l}\text { Female } \\
(\mathrm{N}=101)\end{array}$ \\
\hline \multicolumn{13}{|c|}{ Q24. Give an example of a problem or a conflict that the members of your community encounter often } \\
\hline $\begin{array}{l}\text { Conflict between breeders and } \\
\text { farmers }\end{array}$ & $29(29.0)$ & $27(26.2)$ & $34(33.3)$ & $27(27.0)$ & $30(29.7)$ & $27(27.3)$ & $25(25.0)$ & $32(31.7)$ & $25(25.3)$ & $21(21.0)$ & $26(25.5)$ & $29(28.7)$ \\
\hline Land conflict & $37(37.0)$ & $37(35.9)$ & $40(39.2)$ & $34(34.0)$ & $59(58.4)$ & $52(52.5)$ & $61(61.0)$ & $53(52.5)$ & $44(44.4)$ & $52(52.0)$ & $52(51.0)$ & $41(40.6)$ \\
\hline $\begin{array}{l}\text { Conflict of ethnic/nationality } \\
\text { affiliation }\end{array}$ & $7(7.0)$ & $5(4.9)$ & $1(1.0)$ & $3(3.0)$ & $1(1.0)$ & $1(1.0)$ & $0(0.0)$ & $2(2.0)$ & $4(4.0)$ & $2(2.0)$ & $3(2.9)$ & $4(4.0)$ \\
\hline $\begin{array}{l}\text { Conflict relating to } \\
\text { culture/traditions/customs }\end{array}$ & $10(10.0)$ & $11(10.7)$ & $10(9.8)$ & $12(12.0)$ & $4(4.0)$ & $5(5.1)$ & $4(4.0)$ & $5(5.0)$ & $13(13.1)$ & $18(18.0)$ & $8(7.8)$ & $10(9.9)$ \\
\hline Other & $17(17.0)$ & $23(22.3)$ & $17(16.7)$ & $24(24.0)$ & $7(6.9)$ & $14(14.1)$ & $10(10.0)$ & $9(8.9)$ & $13(13.1)$ & $7(7.0)$ & $13(12.7)$ & $17(16.8)$ \\
\hline The national government & $23(23.0)$ & $21(20.4)$ & $22(21.6)$ & $23(23.0)$ & $34(33.7)$ & $29(29.3)$ & $26(26.0)$ & $20(19.8)$ & $32(32.0)$ & $31(31.0)$ & $25(24.5)$ & $27(26.7)$ \\
\hline The local government & $40(40.0)$ & $26(25.2)$ & $19(18.6)$ & $21(21.0)$ & $36(35.6)$ & $34(34.3)$ & $24(24.0)$ & $38(37.6)$ & $53(53.0)$ & $44(44.0)$ & $44(43.1)$ & $44(43.6)$ \\
\hline Traditional authorities & $28(28.0)$ & $33(32.0)$ & $48(47.1)$ & $46(46.0)$ & $27(26.7)$ & $30(30.3)$ & $37(37.0)$ & $28(27.7)$ & $12(12.0)$ & $20(20.0)$ & $33(32.4)$ & $28(27.7)$ \\
\hline Religious authorities & $6(6.0)$ & $17(16.5)$ & $8(7.8)$ & $5(5.0)$ & $3(3.0)$ & $5(5.1)$ & $13(13.0)$ & $15(14.9)$ & $3(3.0)$ & $2(2.0)$ & $0(0.0)$ & $2(2.0)$ \\
\hline Other [ask who:] & $2(2.0)$ & $1(1.0)$ & $2(2.0)$ & $2(2.0)$ & $1(1.0)$ & $1(1.0)$ & $0(0.0)$ & $0(0.0)$ & $0(0.0)$ & $1(1.0)$ & $0(0.0)$ & $0(0.0)$ \\
\hline Don't know & $1(1.0)$ & $5(4.9)$ & $3(2.9)$ & $3(3.0)$ & $0(0.0)$ & $0(0.0)$ & $0(0.0)$ & $0(0.0)$ & $0(0.0)$ & $1(1.0)$ & $0(0.0)$ & $0(0.0)$ \\
\hline Refused to answer & $0(0.0)$ & $0(0.0)$ & $0(0.0)$ & $0(0.0)$ & $0(0.0)$ & $0(0.0)$ & $0(0.0)$ & $0(0.0)$ & $0(0.0)$ & $1(1.0)$ & $0(0.0)$ & $0(0.0)$ \\
\hline
\end{tabular}

Table 2 : Legal obligation

\begin{tabular}{|c|c|c|c|c|c|c|c|c|c|c|c|c|}
\hline & \multicolumn{2}{|c|}{ Faramana } & \multicolumn{2}{|l|}{ Koury } & \multicolumn{2}{|l|}{ Koloko } & \multicolumn{2}{|l|}{ Finkolo } & \multicolumn{2}{|l|}{ Tansila } & \multicolumn{2}{|l|}{ Boura } \\
\hline & $\begin{array}{l}\text { Male } \\
(\mathrm{N}=100)\end{array}$ & $\begin{array}{l}\text { Female } \\
(\mathrm{N}=103)\end{array}$ & $\begin{array}{l}\text { Male } \\
(\mathrm{N}=102)\end{array}$ & $\begin{array}{l}\text { Female } \\
(\mathrm{N}=100)\end{array}$ & $\begin{array}{l}\text { Male } \\
(\mathrm{N}=101)\end{array}$ & $\begin{array}{l}\text { Female } \\
(\mathrm{N}=99)\end{array}$ & $\begin{array}{l}\text { Male } \\
(\mathrm{N}=100)\end{array}$ & $\begin{array}{l}\text { Female } \\
(101)\end{array}$ & $\begin{array}{l}\text { Male } \\
(\mathrm{N}=100)\end{array}$ & $\begin{array}{l}\text { Female } \\
(\mathrm{N}=100)\end{array}$ & $\begin{array}{l}\text { Male } \\
(\mathrm{N}=102)\end{array}$ & $\begin{array}{l}\text { Female } \\
(\mathrm{N}=101)\end{array}$ \\
\hline \multicolumn{13}{|c|}{ Q112. To the best of your knowledge, is female genital mutilation/cutting legal in Burkina Faso/Mali? } \\
\hline Yes & $6(6.0)$ & $8(7.8)$ & $14(13.7)$ & $15(15.0)$ & $6(5.9)$ & $11(11.1)$ & $17(17.0)$ & $18(17.8)$ & $7(7.0)$ & $7(7.0)$ & $11(10.8)$ & $14(13.9)$ \\
\hline No & $88(88.0)$ & $78(75.7)$ & $83(81.4)$ & $65(65.0)$ & $94(93.1)$ & $85(85.9)$ & $83(83.0)$ & $80(79.2)$ & $87(87.0)$ & $91(91.0)$ & $89(87.3)$ & $82(81.2)$ \\
\hline Don't know & $6(6.0)$ & $17(16.5)$ & $5(4.9)$ & $20(20.0)$ & $1(1.0)$ & $3(3.0)$ & $0(0.0)$ & $3(3.0)$ & $6(6.0)$ & $2(2.0)$ & $2(2.0)$ & $5(5.0)$ \\
\hline \multicolumn{13}{|c|}{ Q113. To the best of your knowledge, is cutting wood in the forest/bush legal in Burkina Faso/Mali? } \\
\hline Yes & $11(11.0)$ & $9(8.7)$ & $33(32.4)$ & $19(19.0)$ & $1(1.0)$ & $5(5.1)$ & $28(28.0)$ & $30(29.7)$ & $9(9.0)$ & $16(8.0)$ & $19(18.6)$ & $17(16.8)$ \\
\hline No & $83(83.0)$ & $88(85.4)$ & $63(61.8)$ & $62(62.0)$ & $100(99.0)$ & $93(93.9)$ & $71(71.0)$ & $66(65.3)$ & $87(87.0)$ & $179(89.5)$ & $83(81.4)$ & $82(81.2)$ \\
\hline Don't know & $6(6.0)$ & $6(5.8)$ & $6(5.9)$ & $18(18.0)$ & $0(0.0)$ & $1(1.0)$ & $1(1.0)$ & $4(4.0)$ & $4(4.0)$ & $5(2.5)$ & $0(0.0)$ & $2(2.0)$ \\
\hline Refused to answer & $0(0.0)$ & $0(0.0)$ & $0(0.0)$ & $1(1.0)$ & $0(0.0)$ & $0(0.0)$ & $0(0.0)$ & $1(1.0)$ & $0(0.0)$ & $0(0.0)$ & $0(0.0)$ & $0(0.0)$ \\
\hline \multicolumn{13}{|c|}{ Q114. To the best of your knowledge, is paying police a bribe to avoid trouble legal in Burkina Faso/Mali? } \\
\hline Yes & $18(18.0)$ & $16(15.5)$ & $22(21.6)$ & $15(15.0)$ & $8(7.9)$ & $9(9.1)$ & $23(23.0)$ & $31(30.7)$ & $5(5.0)$ & $13(6.5)$ & $11(10.8)$ & $16(15.8)$ \\
\hline No & $74(74.0)$ & $82(79.6)$ & $68(66.7)$ & $70(70.0)$ & $93(92.1)$ & 89 (89.9) & $77(77.0)$ & $69(68.3)$ & $94(94.0)$ & $185(92.5)$ & 89 (87.3) & $83(82.2)$ \\
\hline
\end{tabular}




\begin{tabular}{|c|c|c|c|c|c|c|c|c|c|c|c|c|}
\hline & \multicolumn{2}{|c|}{ Faramana } & \multicolumn{2}{|l|}{ Koury } & \multicolumn{2}{|l|}{ Koloko } & \multicolumn{2}{|l|}{ Finkolo } & \multicolumn{2}{|l|}{ Tansila } & \multicolumn{2}{|l|}{ Boura } \\
\hline & $\begin{array}{l}\text { Male } \\
(\mathrm{N}=100)\end{array}$ & $\begin{array}{l}\text { Female } \\
(\mathrm{N}=103)\end{array}$ & \begin{tabular}{|l|} 
Male \\
$(\mathrm{N}=102)$
\end{tabular} & $\begin{array}{l}\text { Female } \\
(N=100)\end{array}$ & $\begin{array}{l}\text { Male } \\
(\mathrm{N}=101)\end{array}$ & $\begin{array}{l}\text { Female } \\
(\mathrm{N}=99)\end{array}$ & $\begin{array}{l}\text { Male } \\
(\mathrm{N}=100)\end{array}$ & $\begin{array}{l}\text { Female } \\
(101)\end{array}$ & $\begin{array}{l}\text { Male } \\
(N=100)\end{array}$ & $\begin{array}{l}\text { Female } \\
(\mathrm{N}=100)\end{array}$ & $\begin{array}{l}\text { Male } \\
(\mathrm{N}=102)\end{array}$ & $\begin{array}{l}\text { Female } \\
(\mathrm{N}=101)\end{array}$ \\
\hline Don't know & $7(7.0)$ & $3(2.9)$ & $12(11.8)$ & $15(15.0)$ & $0(0.0)$ & $1(1.0)$ & $0(0.0)$ & $1(1.0)$ & $1(1.0)$ & $2(1.0)$ & $2(2.0)$ & $2(2.0)$ \\
\hline Refused to answer & $1(1.0)$ & $2(1.9)$ & $0(0.0)$ & $0(0.0)$ & $0(0.0)$ & $0(0.0)$ & $0(0.0)$ & $0(0.0)$ & $0(0.0)$ & $0(0.0)$ & $0(0.0)$ & $0(0.0)$ \\
\hline \multicolumn{13}{|c|}{ Q115. In your opinion, do people have a legal obligation to comply with a law prohibiting female genital mutilation/cutting? } \\
\hline Yes & $64(64.0)$ & $64(62.1)$ & $62(60.8)$ & $51(51.0)$ & $71(70.3)$ & $69(69.7)$ & $59(59.0)$ & $54(53.5)$ & $67(67.0)$ & $66(66.0)$ & $75(73.5)$ & $71(70.3)$ \\
\hline No & $33(33.0)$ & $25(24.3)$ & $36(35.3)$ & $34(34.0)$ & $30(29.7)$ & $30(30.3)$ & $41(41.0)$ & $45(44.6)$ & $33(33.0)$ & $34(34.0)$ & $27(26.5)$ & $28(27.7)$ \\
\hline Don't know & $3(3.0)$ & $14(13.6)$ & $4(3.9)$ & $15(15.0)$ & $0(0.0)$ & $0(0.0)$ & $0(0.0)$ & $2(2.0)$ & $0(0.0)$ & $0(0.0)$ & $0(0.0)$ & $2(2.0)$ \\
\hline \multicolumn{13}{|c|}{ Q116. In your opinion, do people have a legal obligation to comply with a law prohibiting cutting wood in the forest/bush? } \\
\hline Yes & $82(82.0)$ & $73(70.9)$ & $55(53.9)$ & $52(52.0)$ & $81(80.2)$ & $78(78.8)$ & $40(40.0)$ & $49(48.5)$ & $77(77.0)$ & $68(68.0)$ & $69(67.6)$ & $59(58.4)$ \\
\hline No & $17(17.0)$ & $25(24.3)$ & $44(43.1)$ & $39(39.0)$ & $20(19.8)$ & $21(21.2)$ & $60(60.0)$ & $52(51.5)$ & $22(22.0)$ & $31(31.0)$ & $33(32.4)$ & $42(41.6)$ \\
\hline Don't know & $1(1.0)$ & $5(4.9)$ & $3(2.9)$ & $7(7.0)$ & $0(0.0)$ & $0(0.0)$ & $0(0.0)$ & $0(0.0)$ & $1(1.0)$ & $1(1.0)$ & $0(0.0)$ & $0(0.0)$ \\
\hline Refused to Answer & $0(0.0)$ & $0(0.0)$ & $0(0.0)$ & $2(2.0)$ & $0(0.0)$ & $0(0.0)$ & $0(0.0)$ & $0(0.0)$ & $0(0.0)$ & $0(0.0)$ & $0(0.0)$ & $0(0.0)$ \\
\hline \multicolumn{13}{|c|}{ Q117. In your opinion, do people have a legal obligation to comply with a law prohibiting paying police a bribe to avoid trouble? } \\
\hline Yes & $67(67.0)$ & $63(61.2)$ & $54(52.9)$ & $50(50.0)$ & $73(72.3)$ & $72(72.7)$ & $49(49.0)$ & $47(46.5)$ & $72(72.0)$ & $68(68.0)$ & $65(63.7)$ & $60(59.4)$ \\
\hline No & $31(31.0)$ & $34(33.0)$ & $44(43.1)$ & $44(44.0)$ & $28(27.7)$ & 27 (27.3) & $51(51.0)$ & $54(53.5)$ & $28(28.0)$ & $31(31.0)$ & $37(36.3)$ & $41(40.6)$ \\
\hline Don't know & $1(1.0)$ & $6(5.8)$ & 4 (3.9) & $5(5.0)$ & $0(0.0)$ & $0(0.0)$ & $0(0.0)$ & $0(0.0)$ & $0(0.0)$ & $1(1.0)$ & $0(0.0)$ & $0(0.0)$ \\
\hline Refused to answer & $1(1.0)$ & $0(0.0)$ & $0(0.0)$ & $1(1.0)$ & $0(0.0)$ & $0(0.0)$ & $0(0.0)$ & $0(0.0)$ & $0(0.0)$ & $0(0.0)$ & $0(0.0)$ & $0(0.0)$ \\
\hline
\end{tabular}

Table 3: Source of information about the law

\begin{tabular}{|c|c|c|c|c|c|c|c|c|c|c|c|c|}
\hline & \multicolumn{2}{|c|}{ Faramana } & \multicolumn{2}{|c|}{ Koury } & \multicolumn{2}{|l|}{ Koloko } & \multicolumn{2}{|l|}{ Finkolo } & \multicolumn{2}{|l|}{ Tansila } & \multicolumn{2}{|l|}{ Boura } \\
\hline & $\begin{array}{l}\text { Male } \\
(\mathrm{N}=100)\end{array}$ & $\begin{array}{l}\text { Female } \\
(\mathrm{N}=103)\end{array}$ & $\begin{array}{l}\text { Male } \\
(\mathrm{N}=102)\end{array}$ & $\begin{array}{l}\text { Female } \\
(\mathrm{N}=100)\end{array}$ & \begin{tabular}{|l|} 
Male \\
$(\mathrm{N}=101)$
\end{tabular} & $\begin{array}{l}\text { Female } \\
(\mathrm{N}=99)\end{array}$ & \begin{tabular}{|l} 
Male \\
$(\mathrm{N}=100)$
\end{tabular} & $\begin{array}{l}\text { Female } \\
(101)\end{array}$ & $\begin{array}{l}\text { Male } \\
(\mathrm{N}=100)\end{array}$ & $\begin{array}{l}\text { Female } \\
(\mathrm{N}=100)\end{array}$ & $\begin{array}{l}\text { Male } \\
(\mathrm{N}=102)\end{array}$ & $\begin{array}{l}\text { Female } \\
(\mathrm{N}=101)\end{array}$ \\
\hline \multicolumn{13}{|l|}{ Legal knowledge [formal law] } \\
\hline Radio & $40(40.0)$ & $34(33.0)$ & $60(58.8)$ & $\begin{array}{l}42 \\
(42.0)\end{array}$ & $38(37.6)$ & $34(34.3)$ & $62(62.0)$ & $\begin{array}{l}55 \\
(54.5)\end{array}$ & $58(58.0)$ & $50(50.0)$ & $65(63.7)$ & $59(58.4)$ \\
\hline Television & $17(17.0)$ & $13(12.6)$ & $17(16.7)$ & $\begin{array}{l}16 \\
(16.0)\end{array}$ & $32(31.7)$ & $27(27.3)$ & $24(24.0)$ & $\begin{array}{l}20 \\
(19.8)\end{array}$ & $16(16.0)$ & $19(19.0)$ & $17(16.7)$ & $17(16.8)$ \\
\hline Newspapers/magazines & $0(0.0)$ & $0(0.0)$ & $0(0.0)$ & $0(0.0)$ & $2(2.0)$ & $0(0.0)$ & $2(2.0)$ & $0(0.0)$ & $3(3.0)$ & $0(0.0)$ & $1(1.0)$ & $1(1.0)$ \\
\hline Family/friends/community & $18(18.0)$ & $33(32.0)$ & $9(8.8)$ & $\begin{array}{l}26 \\
(26.0)\end{array}$ & $15(14.9)$ & $26(26.3)$ & $4(4.0)$ & $\begin{array}{l}14 \\
(13.9)\end{array}$ & $12(12.0)$ & $24(24.0)$ & $5(4.9)$ & $10(9.9)$ \\
\hline $\begin{array}{l}\text { Observation (do as everyone else } \\
\text { does) }\end{array}$ & $4(4.0)$ & $8(7.8)$ & $3(2.9)$ & $2(2.0)$ & $4(4.0)$ & $1(1.0)$ & $0(0.0)$ & $3(3.0)$ & $5(5.0)$ & $3(3.0)$ & $3(2.9)$ & $6(5.9)$ \\
\hline Elected officials & $15(15.0)$ & $7(6.8)$ & $3(2.9)$ & $5(5.0)$ & $2(2.0)$ & $5(5.1)$ & $5(5.0)$ & $6(5.9)$ & $5(5.0)$ & $2(2.0)$ & $9(8.8)$ & $7(6.9)$ \\
\hline Traditional authorities & $0(0.0)$ & $4(3.9)$ & $7(6.9)$ & $2(2.0)$ & $0(0.0)$ & $0(0.0)$ & $1(1.0)$ & $2(2.0)$ & $1(1.0)$ & $1(1.0)$ & $0(0.0)$ & $0(0.0)$ \\
\hline Religious authorities & $1(1.0)$ & $0(0.0)$ & $1(1.0)$ & $1(1.0)$ & $1(1.0)$ & $1(1.0)$ & $1(1.0)$ & $0(0.0)$ & $0(0.0)$ & $0(0.0)$ & $0(0.0)$ & $0(0.0)$ \\
\hline Other & $4(4.0)$ & $2(1.9)$ & $2(2.0)$ & $3(3.0)$ & $7(6.9)$ & $5(5.1)$ & $1(1.0)$ & $1(1.0)$ & $0(0.0)$ & $1(1.0)$ & $2(2.0)$ & $1(1.0)$ \\
\hline Don't know & $1(1.0)$ & $2(1.9)$ & $0(0.0)$ & $3(3.0)$ & $0(0.0)$ & $0(0.0)$ & $0(0.0)$ & $0(0.0)$ & $0(0.0)$ & $0(0.0)$ & $0(0.0)$ & $0(0.0)$ \\
\hline Legal knowledge [customary law] & & & & & & & & & & & & \\
\hline
\end{tabular}




\begin{tabular}{|c|c|c|c|c|c|c|c|c|c|c|c|c|}
\hline & \multicolumn{2}{|l|}{ Faramana } & \multicolumn{2}{|c|}{ Koury } & \multicolumn{2}{|l|}{ Koloko } & \multicolumn{2}{|l|}{ Finkolo } & \multicolumn{2}{|l|}{ Tansila } & \multicolumn{2}{|l|}{ Boura } \\
\hline & $\begin{array}{l}\text { Male } \\
(\mathrm{N}=100)\end{array}$ & $\begin{array}{l}\text { Female } \\
(\mathrm{N}=103)\end{array}$ & $\begin{array}{l}\text { Male } \\
(\mathrm{N}=102)\end{array}$ & $\begin{array}{l}\text { Female } \\
(N=100)\end{array}$ & $\begin{array}{l}\text { Male } \\
(\mathrm{N}=101)\end{array}$ & $\begin{array}{l}\text { Female } \\
(\mathrm{N}=99)\end{array}$ & $\begin{array}{l}\text { Male } \\
(\mathrm{N}=100)\end{array}$ & $\begin{array}{l}\text { Female } \\
(101)\end{array}$ & $\begin{array}{l}\text { Male } \\
(\mathrm{N}=100)\end{array}$ & $\begin{array}{l}\text { Female } \\
(\mathrm{N}=100)\end{array}$ & $\begin{array}{l}\text { Male } \\
(\mathrm{N}=102)\end{array}$ & $\begin{array}{l}\text { Female } \\
(\mathrm{N}=101)\end{array}$ \\
\hline Radio & $2(2.0)$ & $1(1.0)$ & $7(6.9)$ & $9(9.0)$ & $1(1.0)$ & $2(2.0)$ & $5(5.0)$ & $6(5.9)$ & $2(2.0)$ & $5(5.0)$ & $9(8.8)$ & $11(10.9)$ \\
\hline Television & $4(4.0)$ & $0(0.0)$ & $1(1.0)$ & $1(1.0)$ & $2(2.0)$ & $2(2.0)$ & $0(0.0)$ & $1(1.0)$ & $0(0.0)$ & $1(1.0)$ & $0(0.0)$ & $1(1.0)$ \\
\hline Family/friends/community & $32(32.0)$ & $35(34.0)$ & $36(35.3)$ & $\begin{array}{l}38 \\
(38.0)\end{array}$ & $38(37.6)$ & $48(48.5)$ & $1(1.0)$ & $0(0.0)$ & $1(1.0)$ & $1(1.0)$ & $32(31.4)$ & $37(36.6)$ \\
\hline $\begin{array}{l}\text { Observation (do as everyone else } \\
\text { does) }\end{array}$ & $14(14.0)$ & $20(19.4)$ & $9(8.8)$ & $9(9.0)$ & $8(7.9)$ & $12(12.1)$ & $28(28.0)$ & $\begin{array}{l}48 \\
(47.5)\end{array}$ & $42(42.0)$ & $51(51.0)$ & $20(19.6)$ & $16(15.8)$ \\
\hline Elected officials & $3(3.0)$ & $0(0.0)$ & $5(4.9)$ & $5(5.0)$ & $4(4.0)$ & $7(7.1)$ & $10(10.0)$ & $\begin{array}{l}14 \\
(13.9)\end{array}$ & $15(15.0)$ & $18(18.0)$ & $2(2.0)$ & $2(2.0)$ \\
\hline Traditional authorities & $41(41.0)$ & $42(40.8)$ & $40(39.2)$ & $\begin{array}{l}32 \\
(32.0)\end{array}$ & $42(41.6)$ & $24(24.2)$ & $5(5.0)$ & $2(2.0)$ & $5(5.0)$ & $3(3.0)$ & $34(33.3)$ & $29(28.7)$ \\
\hline Religious authorities & $0(0.0)$ & $1(1.0)$ & $3(2.9)$ & $3(3.0)$ & $2(2.0)$ & $1(1.0)$ & $40(40.0)$ & $\begin{array}{l}25 \\
(24.8)\end{array}$ & $33(33.0)$ & $20(20.0)$ & $4(3.9)$ & $4(4.0)$ \\
\hline Other & $2(2.0)$ & $2(1.9)$ & $0(0.0)$ & $3(3.0)$ & $4(4.0)$ & $3(3.0)$ & $11(11.0)$ & $5(5.0)$ & $1(1.0)$ & $0(0.0)$ & $1(1.0)$ & $1(1.0)$ \\
\hline Don't know & $2(2.0)$ & $2(1.9)$ & $1(1.0)$ & $0(0.0)$ & $0(0.0)$ & $0(0.0)$ & $0(0.0)$ & $0(0.0)$ & $1(1.0)$ & $1(1.0)$ & $0(0.0)$ & $0(0.0)$ \\
\hline
\end{tabular}

Table 4 : Legal punishment

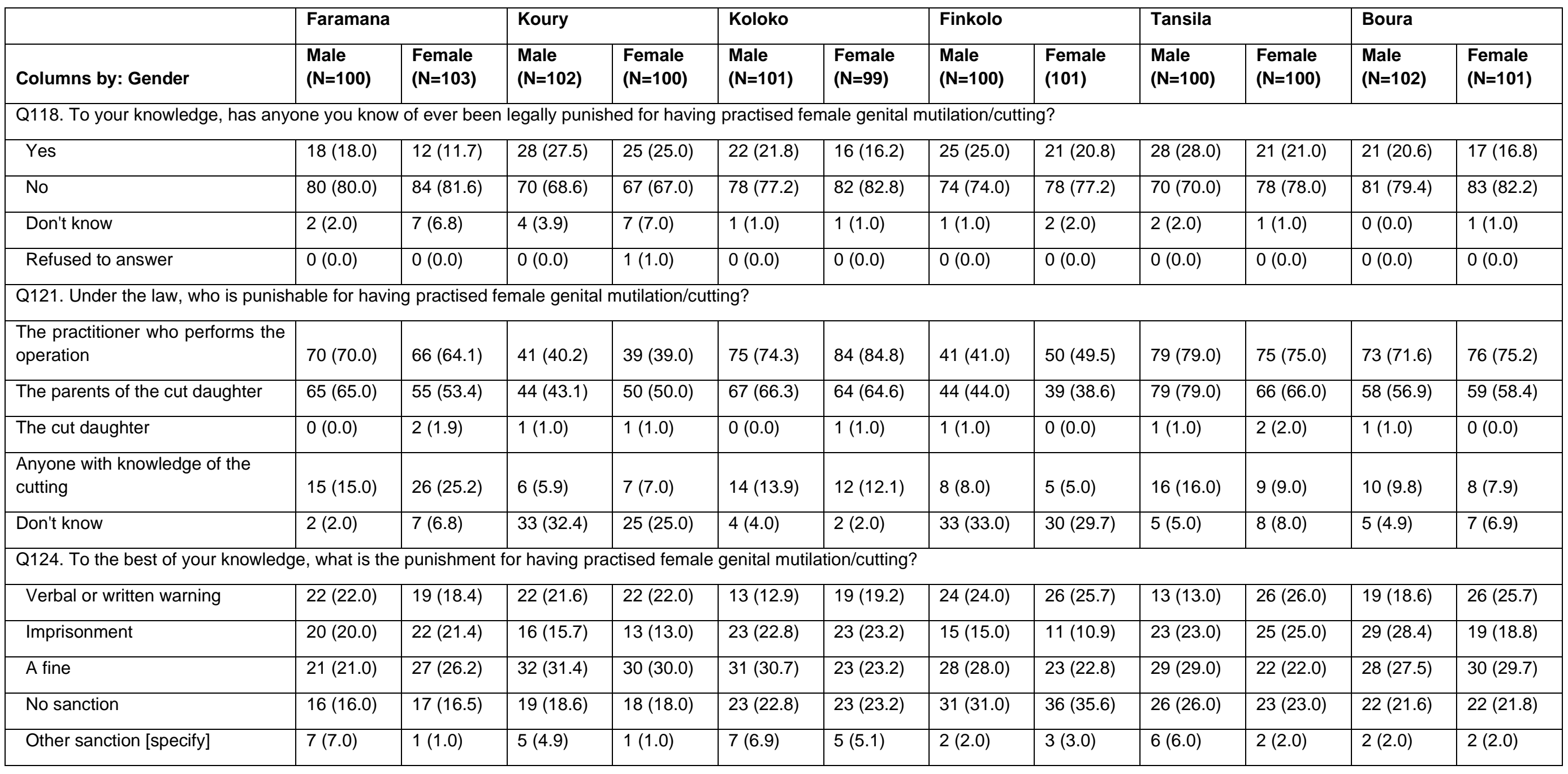




\begin{tabular}{|c|c|c|c|c|c|c|c|c|c|c|c|c|}
\hline Don't know & $14(14.0)$ & 17 (16.5) & $7(6.9)$ & $15(15.0)$ & $4(4.0)$ & $6(6.1)$ & $0(0.0)$ & $2(2.0)$ & $3(3.0)$ & $2(2.0)$ & $2(2.0)$ & $2(2.0)$ \\
\hline Refused to answer & $0(0.0)$ & $0(0.0)$ & $1(1.0)$ & $1(1.0)$ & $0(0.0)$ & $0(0.0)$ & $0(0.0)$ & $0(0.0)$ & $0(0.0)$ & $0(0.0)$ & $0(0.0)$ & $0(0.0)$ \\
\hline
\end{tabular}

Table 5: Who enforces the law?

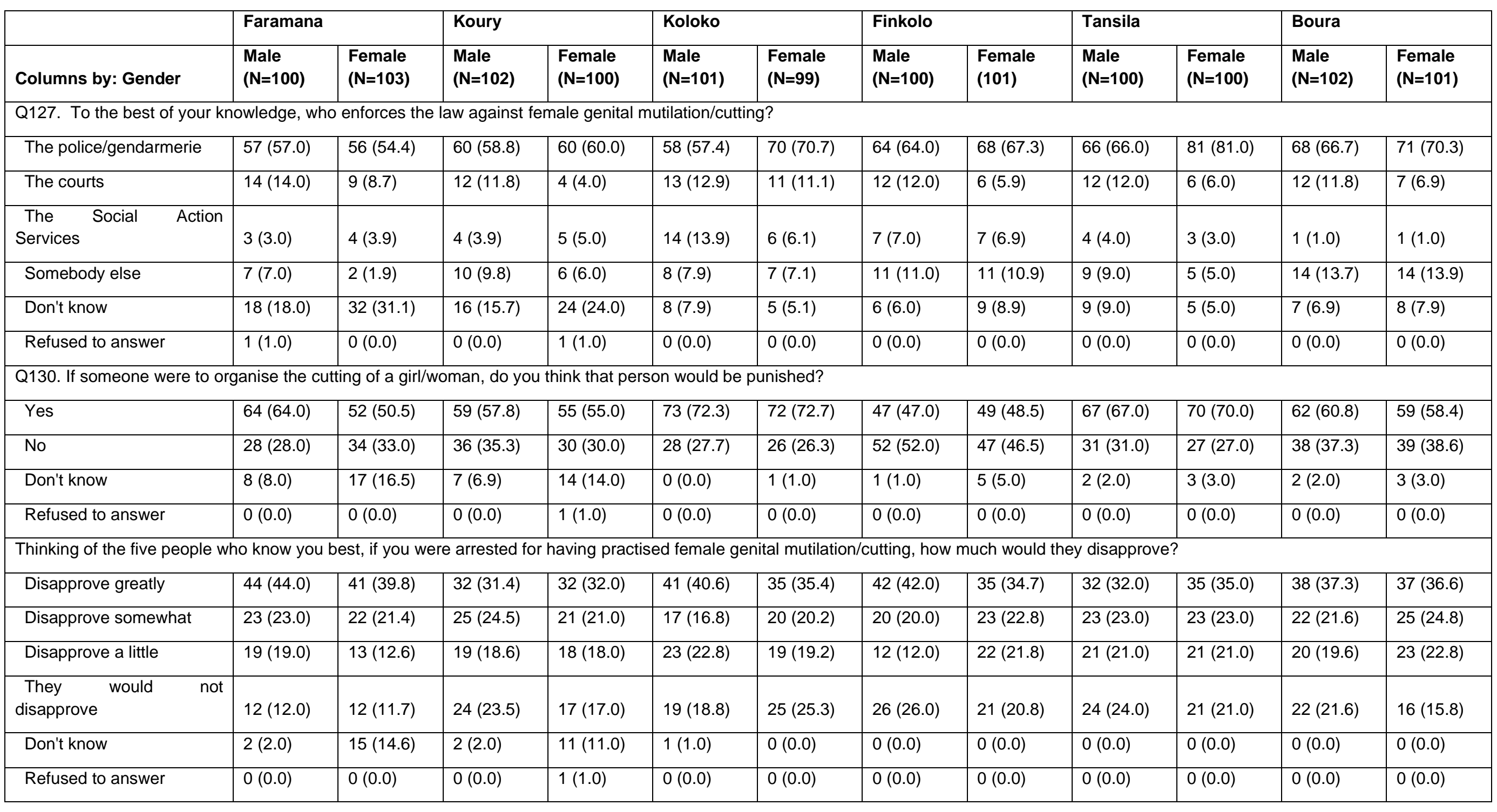

Table 6: Motivations to obey the formal law

\begin{tabular}{|c|c|c|c|c|c|c|c|c|c|c|c|c|}
\hline & \multicolumn{2}{|c|}{ Faramana } & \multicolumn{2}{|l|}{ Koury } & \multicolumn{2}{|l|}{ Koloko } & \multicolumn{2}{|l|}{ Finkolo } & \multicolumn{2}{|l|}{ Tansila } & \multicolumn{2}{|l|}{ Boura } \\
\hline & $\begin{array}{l}\text { Male } \\
(\mathrm{N}=100)\end{array}$ & $\begin{array}{l}\text { Female } \\
(\mathrm{N}=103)\end{array}$ & $\begin{array}{l}\text { Male } \\
(\mathrm{N}=102)\end{array}$ & $\begin{array}{l}\text { Female } \\
(\mathrm{N}=100)\end{array}$ & $\begin{array}{l}\text { Male } \\
(\mathrm{N}=101)\end{array}$ & $\begin{array}{l}\text { Female } \\
(\mathrm{N}=99)\end{array}$ & $\begin{array}{l}\text { Male } \\
(\mathrm{N}=100)\end{array}$ & $\begin{array}{l}\text { Female } \\
(101)\end{array}$ & $\begin{array}{l}\text { Male } \\
(\mathrm{N}=100)\end{array}$ & \begin{tabular}{|l|} 
Female \\
$(\mathrm{N}=100)$
\end{tabular} & $\begin{array}{l}\text { Male } \\
(\mathrm{N}=102)\end{array}$ & $\begin{array}{l}\text { Female } \\
(\mathrm{N}=101)\end{array}$ \\
\hline \multicolumn{13}{|c|}{ Q52: Thinking about the laws of [Burkina Faso / Mali], what motivates YOU most to respect the law? } \\
\hline $\begin{array}{l}\text { Because it is the law and it } \\
\text { must be respected }\end{array}$ & $52(52.0)$ & $54(52.4)$ & $58(56.9)$ & $47(47.0)$ & $60(59.4)$ & $53(53.5)$ & $46(46.0)$ & $56(55.4)$ & $59(59.0)$ & $50(50.0)$ & $63(61.8)$ & $55(54.5)$ \\
\hline $\begin{array}{l}\text { Pleasure of following your } \\
\text { conscience }\end{array}$ & $19(19.0)$ & $6(5.8)$ & $9(8.8)$ & $10(10.0)$ & $16(15.8)$ & $16(16.2)$ & $17(17.0)$ & $19(18.8)$ & $16(16.0)$ & $24(24.0)$ & $16(15.7)$ & $21(20.8)$ \\
\hline Social esteem & $3(3.0)$ & $5(4.9)$ & $4(3.9)$ & $4(4.0)$ & $6(5.9)$ & $2(2.0)$ & $4(4.0)$ & $8(7.9)$ & $2(2.0)$ & $9(9.0)$ & $7(6.9)$ & $7(6.9)$ \\
\hline Fear of leagal sanction & $20(20.0)$ & $27(26.2)$ & $12(11.8)$ & $14(14.0)$ & $8(7.9)$ & $9(9.1)$ & $11(11.0)$ & $13(12.9)$ & $15(15.0)$ & $6(6.0)$ & $5(4.9)$ & $7(6.9)$ \\
\hline
\end{tabular}




\begin{tabular}{|c|c|c|c|c|c|c|c|c|c|c|c|c|}
\hline Fear of guilt & $0(0.0)$ & $2(1.9)$ & $2(2.0)$ & $2(2.0)$ & $0(0.0)$ & $1(1.0)$ & $1(1.0)$ & $0(0.0)$ & $0(0.0)$ & $0(0.0)$ & $1(1.0)$ & $1(1.0)$ \\
\hline $\begin{array}{l}\text { Fear of social sanction } \\
\text { (ancestors, gods) }\end{array}$ & $0(0.0)$ & $2(1.9)$ & $1(1.0)$ & $2(2.0)$ & $0(0.0)$ & $1(1.0)$ & $0(0.0)$ & $0(0.0)$ & $0(0.0)$ & $0(0.0)$ & $0(0.0)$ & $0(0.0)$ \\
\hline Other [specify] & $5(5.0)$ & $6(5.8)$ & $13(12.7)$ & $11(11.0)$ & $11(10.9)$ & $16(16.2)$ & $21(21.0)$ & $5(5.0)$ & $8(8.0)$ & $11(11.0)$ & $10(9.8)$ & $10(9.9)$ \\
\hline Don't know & $1(1.0)$ & $1(1.0)$ & $3(2.9)$ & $9(9.0)$ & $0(0.0)$ & $1(1.0)$ & $0(0.0)$ & $0(0.0)$ & $0(0.0)$ & $0(0.0)$ & $0(0.0)$ & $0(0.0)$ \\
\hline Refused to answer & $0(0.0)$ & $0(0.0)$ & $0(0.0)$ & $1(1.0)$ & $0(0.0)$ & $0(0.0)$ & $0(0.0)$ & $0(0.0)$ & $0(0.0)$ & $0(0.0)$ & $0(0.0)$ & $0(0.0)$ \\
\hline \multicolumn{13}{|c|}{ Q53: With regard to the laws [of Burkina Faso / Mali], what motivates OTHERS most to comply with them? } \\
\hline $\begin{array}{l}\text { Because it is the law and it } \\
\text { must be respected }\end{array}$ & $55(55.0)$ & $43(41.7)$ & $55(53.9)$ & $44(44.0)$ & $57(56.4)$ & $54(54.5)$ & $45(45.0)$ & $54(53.5)$ & $52(52.0)$ & $49(49.0)$ & $62(60.8)$ & $56(55.4)$ \\
\hline $\begin{array}{l}\text { Pleasure of following your } \\
\text { conscience }\end{array}$ & $9(9.0)$ & $8(7.8)$ & $10(9.8)$ & $4(4.0)$ & $9(8.9)$ & $13(13.1)$ & $9(9.0)$ & $16(15.8)$ & $19(19.0)$ & $20(20.0)$ & $13(12.7)$ & $22(21.8)$ \\
\hline Social esteem & $4(4.0)$ & $4(3.9)$ & $2(2.0)$ & $4(4.0)$ & $3(3.0)$ & $2(2.0)$ & $4(4.0)$ & $11(10.9)$ & $2(2.0)$ & $2(2.0)$ & $4(3.9)$ & $1(1.0)$ \\
\hline Fear of legal sanction & $25(25.0)$ & $31(30.1)$ & $14(13.7)$ & $29(29.0)$ & $19(18.8)$ & $16(16.2)$ & $25(25.0)$ & $12(11.9)$ & $23(23.0)$ & $18(18.0)$ & $15(14.7)$ & $15(14.9)$ \\
\hline Fear of guilt & $1(1.0)$ & $1(1.0)$ & $2(2.0)$ & $0(0.0)$ & $2(2.0)$ & $1(1.0)$ & $0(0.0)$ & $2(2.0)$ & $0(0.0)$ & $2(2.0)$ & $1(1.0)$ & $1(1.0)$ \\
\hline $\begin{array}{l}\text { Fear of social sanction } \\
\text { (ancestors, gods) }\end{array}$ & $0(0.0)$ & $5(4.9)$ & $5(4.9)$ & $4(4.0)$ & $3(3.0)$ & $0(0.0)$ & $2(2.0)$ & $2(2.0)$ & $1(1.0)$ & $1(1.0)$ & $0(0.0)$ & $0(0.0)$ \\
\hline Other & $4(4.0)$ & $7(6.8)$ & $8(7.8)$ & $5(5.0)$ & $7(6.9)$ & $10(10.1)$ & $15(15.0)$ & $3(3.0)$ & $3(3.0)$ & $6(6.0)$ & $7(6.9)$ & $6(5.9)$ \\
\hline Don't know & $2(2.0)$ & $4(3.9)$ & $6(5.9)$ & $10(10.0)$ & $1(1.0)$ & $3(3.0)$ & $0(0.0)$ & $1(1.0)$ & $0(0.0)$ & $2(2.0)$ & $0(0.0)$ & $0(0.0)$ \\
\hline
\end{tabular}

Table 7: Motivations to obey the customary law

\begin{tabular}{|c|c|c|c|c|c|c|c|c|c|c|c|c|}
\hline & \multicolumn{2}{|l|}{ Faramana } & \multicolumn{2}{|l|}{ Koury } & \multicolumn{2}{|l|}{ Koloko } & \multicolumn{2}{|l|}{ Finkolo } & \multicolumn{2}{|l|}{ Tansila } & \multicolumn{2}{|l|}{ Boura } \\
\hline & $\begin{array}{l}\text { Male } \\
(\mathrm{N}=100)\end{array}$ & $\begin{array}{l}\text { Female } \\
(\mathrm{N}=103)\end{array}$ & $\begin{array}{l}\text { Male } \\
(\mathrm{N}=102)\end{array}$ & $\begin{array}{l}\text { Female } \\
(\mathrm{N}=100)\end{array}$ & $\begin{array}{l}\text { Male } \\
(\mathrm{N}=101)\end{array}$ & $\begin{array}{l}\text { Female } \\
(\mathrm{N}=99)\end{array}$ & $\begin{array}{l}\text { Male } \\
(\mathrm{N}=100)\end{array}$ & $\begin{array}{l}\text { Female } \\
(101)\end{array}$ & $\begin{array}{l}\text { Male } \\
(\mathrm{N}=100)\end{array}$ & $\begin{array}{l}\text { Female } \\
(\mathrm{N}=100)\end{array}$ & \begin{tabular}{|l} 
Male \\
$(\mathrm{N}=102)$
\end{tabular} & $\begin{array}{l}\text { Female } \\
(\mathrm{N}=101)\end{array}$ \\
\hline \multicolumn{13}{|c|}{ Q54: About the customs and traditions of your community, what motivates YOU most to follow the customary rules? } \\
\hline $\begin{array}{l}\text { Because it is the law and it } \\
\text { must be respected }\end{array}$ & $22(22.0)$ & $20(19.4)$ & $24(23.5)$ & $27(27.0)$ & $27(26.7)$ & $30(30.3)$ & $23(23.0)$ & $31(30.7)$ & $31(31.0)$ & $34(34.0)$ & $43(42.2)$ & $32(31.7)$ \\
\hline $\begin{array}{l}\text { Pleasure of following your } \\
\text { conscience }\end{array}$ & $13(13.0)$ & $6(5.8)$ & $11(10.8)$ & $17(17.0)$ & $21(20.8)$ & $10(10.1)$ & $18(18.0)$ & $18(17.8)$ & $23(23.0)$ & $21(21.0)$ & $23(22.5)$ & $21(20.8)$ \\
\hline Social esteem & $22(22.0)$ & $16(15.5)$ & $15(14.7)$ & $13(13.0)$ & $14(13.9)$ & $21(21.2)$ & $19(19.0)$ & $18(17.8)$ & $15(15.0)$ & $16(16.0)$ & $18(17.6)$ & $23(22.8)$ \\
\hline Fear of legal sanction & $1(1.0)$ & $4(3.9)$ & $1(1.0)$ & $2(2.0)$ & $2(2.0)$ & $3(3.0)$ & $0(0.0)$ & $2(2.0)$ & $1(1.0)$ & $1(1.0)$ & $0(0.0)$ & $0(0.0)$ \\
\hline Fear of guilt & $5(5.0)$ & $1(1.0)$ & $3(2.9)$ & $3(3.0)$ & $2(2.0)$ & $4(4.0)$ & $2(2.0)$ & $1(1.0)$ & $5(5.0)$ & \begin{tabular}{|l|}
$1(1.0)$ \\
\end{tabular} & $1(1.0)$ & $2(2.0)$ \\
\hline $\begin{array}{l}\text { Fear of the social sanctions } \\
\text { (ancestors, gods) }\end{array}$ & $23(23.0)$ & 38 (36.9) & $22(21.6)$ & $15(15.0)$ & $22(21.8)$ & $15(15.2)$ & $20(20.0)$ & $18(17.8)$ & $19(19.0)$ & $19(19.0)$ & $7(6.9)$ & $17(16.8)$ \\
\hline Other (specify) & $9(9.0)$ & $10(9.7)$ & $21(20.6)$ & $12(12.0)$ & $12(11.9)$ & $15(15.2)$ & $18(18.0)$ & $13(12.9)$ & $6(6.0)$ & $8(8.0)$ & $10(9.8)$ & $6(5.9)$ \\
\hline Don't know & $5(5.0)$ & $8(7.8)$ & $5(4.9)$ & $10(10.0)$ & $1(1.0)$ & $1(1.0)$ & $0(0.0)$ & $0(0.0)$ & $0(0.0)$ & $0(0.0)$ & $0(0.0)$ & $0(0.0)$ \\
\hline Refused to answer & $0(0.0)$ & $0(0.0)$ & $0(0.0)$ & $1(1.0)$ & $0(0.0)$ & $0(0.0)$ & $0(0.0)$ & $0(0.0)$ & $0(0.0)$ & $0(0.0)$ & $0(0.0)$ & $0(0.0)$ \\
\hline \multicolumn{13}{|c|}{ Q55: With regard to the customs and traditions of your community, what do you think motivates OTHERS most to follow the customary rules? } \\
\hline $\begin{array}{l}\text { Because it is the law and it } \\
\text { must be respected }\end{array}$ & $20(20.0)$ & 17 (16.5) & $24(23.5)$ & $22(22.0)$ & 27 (26.7) & 31 (31.3) & $24(24.0)$ & $28(27.7)$ & $31(31.0)$ & $35(35.0)$ & 40 (39.2) & $32(31.7)$ \\
\hline $\begin{array}{l}\text { Pleasure of following your } \\
\text { conscience }\end{array}$ & $13(13.0)$ & $5(4.9)$ & $13(12.7)$ & $16(16.0)$ & 12 (11.9) & $7(7.1)$ & $14(14.0)$ & 15 (14.9) & $18(18.0)$ & $16(16.0)$ & $20(19.6)$ & $23(22.8)$ \\
\hline
\end{tabular}




\begin{tabular}{|c|c|c|c|c|c|c|c|c|c|c|c|c|}
\hline & \multicolumn{2}{|c|}{ Faramana } & \multicolumn{2}{|l|}{ Koury } & \multicolumn{2}{|l|}{ Koloko } & \multicolumn{2}{|l|}{ Finkolo } & \multicolumn{2}{|l|}{ Tansila } & \multicolumn{2}{|l|}{ Boura } \\
\hline & $\begin{array}{l}\text { Male } \\
(\mathrm{N}=100)\end{array}$ & \begin{tabular}{|l|} 
Female \\
$(\mathrm{N}=103)$
\end{tabular} & $\begin{array}{l}\text { Male } \\
(\mathrm{N}=102)\end{array}$ & $\begin{array}{l}\text { Female } \\
(\mathrm{N}=100)\end{array}$ & \begin{tabular}{|l|} 
Male \\
$(\mathrm{N}=101)$
\end{tabular} & $\begin{array}{l}\text { Female } \\
(\mathrm{N}=99)\end{array}$ & $\begin{array}{l}\text { Male } \\
(\mathrm{N}=100)\end{array}$ & \begin{tabular}{|l} 
Female \\
$(101)$
\end{tabular} & $\begin{array}{l}\text { Male } \\
(\mathrm{N}=100)\end{array}$ & $\begin{array}{l}\text { Female } \\
(\mathrm{N}=100)\end{array}$ & $\begin{array}{l}\text { Male } \\
(\mathrm{N}=102)\end{array}$ & $\begin{array}{l}\text { Female } \\
(\mathrm{N}=101)\end{array}$ \\
\hline Social esteem & $18(18.0)$ & $18(17.5)$ & $12(11.8)$ & $9(9.0)$ & $9(8.9)$ & $15(15.2)$ & $15(15.0)$ & $15(14.9)$ & $14(14.0)$ & $7(7.0)$ & $14(13.7)$ & $9(8.9)$ \\
\hline Fear of legal sanction & $0(0.0)$ & $2(1.9)$ & $4(3.9)$ & $5(5.0)$ & $2(2.0)$ & $2(2.0)$ & $1(1.0)$ & $3(3.0)$ & $2(2.0)$ & $1(1.0)$ & $0(0.0)$ & $0(0.0)$ \\
\hline Fear of guilt & $2(2.0)$ & $0(0.0)$ & $1(1.0)$ & $0(0.0)$ & $5(5.0)$ & $4(4.0)$ & $32(32.0)$ & $33(32.7)$ & $1(1.0)$ & $4(4.0)$ & $1(1.0)$ & $0(0.0)$ \\
\hline $\begin{array}{l}\text { Fear of the social sanctions } \\
\text { (ancestors, gods) }\end{array}$ & $35(35.0)$ & $47(45.6)$ & $32(31.4)$ & $30(30.0)$ & $40(39.6)$ & 32 (32.3) & $14(14.0)$ & $6(5.9)$ & $30(30.0)$ & $33(33.0)$ & $18(17.6)$ & $33(32.7)$ \\
\hline Other (specify) & $6(6.0)$ & $6(5.8)$ & $9(8.8)$ & $7(7.0)$ & $5(5.0)$ & $7(7.1)$ & $0(0.0)$ & $1(1.0)$ & $3(3.0)$ & $3(3.0)$ & $9(8.8)$ & $4(4.0)$ \\
\hline Don't know & $6(6.0)$ & $8(7.8)$ & $7(6.9)$ & $11(11.0)$ & $1(1.0)$ & $1(1.0)$ & $0(0.0)$ & $0(0.0)$ & $1(1.0)$ & $1(1.0)$ & $0(0.0)$ & $0(0.0)$ \\
\hline Refused to answer & $0(0.0)$ & $0(0.0)$ & $0(0.0)$ & $1(1.0)$ & $0(0.0)$ & $0(0.0)$ & $0(0.0)$ & $0(0.0)$ & $0(0.0)$ & $0(0.0)$ & $0(0.0)$ & $0(0.0)$ \\
\hline
\end{tabular}

Table 8: Reasons for disobeying the formal law in Burkina Faso and Mali

\begin{tabular}{|c|c|c|c|c|c|c|c|c|c|c|c|c|}
\hline & \multicolumn{2}{|l|}{ Faramana } & \multicolumn{2}{|l|}{ Koury } & \multicolumn{2}{|l|}{ Koloko } & \multicolumn{2}{|l|}{ Finkolo } & \multicolumn{2}{|l|}{ Tansila } & \multicolumn{2}{|l|}{ Boura } \\
\hline & $\begin{array}{l}\text { Male } \\
(\mathrm{N}=100)\end{array}$ & $\begin{array}{l}\text { Female } \\
(\mathrm{N}=103)\end{array}$ & $\begin{array}{l}\text { Male } \\
(\mathrm{N}=102)\end{array}$ & $\begin{array}{l}\text { Female } \\
(\mathrm{N}=100)\end{array}$ & $\begin{array}{l}\text { Male } \\
(\mathrm{N}=101)\end{array}$ & \begin{tabular}{|l|} 
Female \\
$(\mathrm{N}=99)$
\end{tabular} & $\begin{array}{l}\text { Male } \\
(\mathrm{N}=100)\end{array}$ & $\begin{array}{l}\text { Female } \\
\text { (101) }\end{array}$ & $\begin{array}{l}\text { Male } \\
(\mathrm{N}=100)\end{array}$ & $\begin{array}{l}\text { Female } \\
(\mathrm{N}=100)\end{array}$ & $\begin{array}{l}\text { Male } \\
(\mathrm{N}=102)\end{array}$ & $\begin{array}{l}\text { Female } \\
(\mathrm{N}=101)\end{array}$ \\
\hline \multicolumn{13}{|c|}{ Q29. Why would people here think it is acceptable to disobey the official law [of Mali /Burkina Faso]? } \\
\hline $\begin{array}{l}\text { Contradiction with religion/ } \\
\text { customs (Yes) }\end{array}$ & $29(29.0)$ & $37(35.9)$ & $34(33.3)$ & $26(26.0)$ & $26(25.7)$ & $28(28.3)$ & $28(28.0)$ & $33(32.7)$ & $24(24.0)$ & $26(26.0)$ & $21(20.6)$ & $26(25.7)$ \\
\hline I disagree with the law (Yes) & $20(20.0)$ & $21(20.4)$ & $31(30.4)$ & $31(31.0)$ & $29(28.7)$ & $32(32.3)$ & $25(25.0)$ & $36(35.6)$ & $28(28.0)$ & $34(34.0)$ & $26(25.5)$ & $30(29.7)$ \\
\hline $\begin{array}{l}\text { The authorities do not obey } \\
\text { the law (Yes) }\end{array}$ & $14(14.0)$ & $16(15.5)$ & $26(25.5)$ & $15(15.0)$ & $16(15.8)$ & $19(19.2)$ & $32(32.0)$ & $22(21.8)$ & $28(28.0)$ & $26(26.0)$ & $36(35.3)$ & $24(23.8)$ \\
\hline $\begin{array}{l}\text { Lack of sanctions when the } \\
\text { law is not enforced (Yes) }\end{array}$ & $13(13.0)$ & $21(20.4)$ & $4(3.9)$ & $4(4.0)$ & $13(12.9)$ & $12(12.1)$ & $9(9.0)$ & $14(13.9)$ & $18(18.0)$ & $17(17.0)$ & $17(16.7)$ & $20(19.8)$ \\
\hline Other (specify) (Yes) & $28(28.0)$ & $13(12.6)$ & $27(26.5)$ & $19(19.0)$ & $36(35.6)$ & $26(26.3)$ & $32(32.0)$ & $19(18.8)$ & $28(28.0)$ & $16(16.0)$ & $21(20.6)$ & $20(19.8)$ \\
\hline Don't know (Yes) & $15(15.0)$ & $22(21.4)$ & $4(3.9)$ & $21(21.0)$ & $2(2.0)$ & $3(3.0)$ & $0(0.0)$ & $1(1.0)$ & $0(0.0)$ & $0(0.0)$ & $0(0.0)$ & $1(1.0)$ \\
\hline Refused to respond (Yes) & $0(0.0)$ & $0(0.0)$ & $0(0.0)$ & $0(0.0)$ & $1(1.0)$ & $0(0.0)$ & $0(0.0$ & $0(0.0$ & $0(0.0)$ & $0(0.0)$ & $0(0.0)$ & $0(0.0)$ \\
\hline \multicolumn{13}{|c|}{ Q30. Why would people here say that it is permissible to disobey [Mali / Burkina Faso] customary law? } \\
\hline $\begin{array}{l}\text { Contradiction with the religion } \\
\text { (Yes) }\end{array}$ & $44(44.0)$ & $44(42.7)$ & $49(48.0)$ & $43(43.0)$ & $49(48.5)$ & $47(47.5)$ & $40(40.0)$ & $50(49.5)$ & $60(60.0)$ & $64(64.0)$ & $61(59.8)$ & $61(60.4)$ \\
\hline $\begin{array}{l}\text { The law is outdated/retrograde } \\
\text { (Yes) }\end{array}$ & $26(26.0)$ & $27(26.2)$ & $18(17.6)$ & $19(19.0)$ & $27(26.7)$ & $25(25.3)$ & $24(24.0)$ & $20(19.8)$ & $15(15.0)$ & $26(26.0)$ & $25(24.5)$ & $22(21.8)$ \\
\hline $\begin{array}{l}\text { Contradiction with the official } \\
\text { law (Yes) }\end{array}$ & $8(8.0)$ & $3(2.9)$ & $3(2.9)$ & $5(5.0)$ & $7(6.9)$ & $6(6.1)$ & $4(4.0)$ & $4(4.0)$ & $13(13.0)$ & $10(10.0)$ & $9(8.8)$ & $7(6.9)$ \\
\hline Too restrictive (Yes) & $23(23.0)$ & $24(23.3)$ & $15(14.7)$ & $14(14.0)$ & $18(17.8)$ & $18(18.2)$ & $19(19.0)$ & $22(21.8)$ & $24(24.0)$ & $20(20.0)$ & $18(17.6)$ & $17(16.8)$ \\
\hline The law is segregationist (Yes) & $9(9.0)$ & $10(9.7)$ & $10(9.8)$ & $3(3.0)$ & $13(12.9)$ & $4(4.0)$ & $14(14.0)$ & $9(8.9)$ & $8(8.0)$ & $7(7.0)$ & $7(6.9)$ & $9(8.9)$ \\
\hline Other (specify) (Yes) & $7(7.0)$ & $10(9.7)$ & $22(21.6)$ & $16(16.0)$ & $17(16.8)$ & $17(17.2)$ & $26(26.0)$ & $22(21.8)$ & $11(11.0)$ & $14(14.0)$ & $16(15.7)$ & $15(14.9)$ \\
\hline Don't know (Yes) & $10(10.0)$ & $13(12.6)$ & $5(4.9)$ & $16(16.0)$ & $1(1.0)$ & $2(2.0)$ & $0(0.0)$ & $2(2.0)$ & $0(0.0)$ & $0(0.0)$ & $0(0.0)$ & $0(0.0)$ \\
\hline Refused to answer (Yes) & $0(0.0)$ & $0(0.0)$ & $0(0.0)$ & $2(2.0)$ & $0(0.0)$ & $0(0.0)$ & $0(0.0)$ & $0(0.0)$ & $0(0.0)$ & $0(0.0)$ & $0(0.0)$ & $0(0.0)$ \\
\hline
\end{tabular}




\begin{tabular}{|c|c|c|c|c|c|c|c|c|c|c|c|c|}
\hline & Faramane & & Koury & & Koloko & & Finkolo & & Tansila & & Boura & \\
\hline $\begin{array}{l}\text { It is acceptable to break } \\
\text { the formal law [of Burkina } \\
\text { Faso/ Mali]; }\end{array}$ & $\begin{array}{l}\text { Male } \\
(\mathrm{N}=100)\end{array}$ & $\begin{array}{l}\text { Female } \\
(\mathrm{N}=103)\end{array}$ & $\begin{array}{l}\text { Male } \\
(\mathrm{N}=102)\end{array}$ & $\begin{array}{l}\text { Female } \\
(N=100)\end{array}$ & $\begin{array}{l}\text { Male } \\
(\mathrm{N}=101)\end{array}$ & $\begin{array}{l}\text { Female } \\
(\mathrm{N}=99)\end{array}$ & $\begin{array}{l}\text { Male } \\
(\mathrm{N}=100)\end{array}$ & $\begin{array}{l}\text { Female } \\
(101)\end{array}$ & $\begin{array}{l}\text { Male } \\
(\mathrm{N}=100)\end{array}$ & $\begin{array}{l}\text { Female } \\
(N=100)\end{array}$ & $\begin{array}{l}\text { Male } \\
(\mathrm{N}=102)\end{array}$ & $\begin{array}{l}\text { Female } \\
(\mathrm{N}=101)\end{array}$ \\
\hline $\begin{array}{l}\text { Q31: If this law is clearly } \\
\text { against one's morals and } \\
\text { principles? }\end{array}$ & $59(59.0)$ & $61(59.2)$ & $64(62.7)$ & $61(61.0)$ & $63(62.4)$ & $70(70.7)$ & $63(62.4)$ & $70(70.7)$ & $65(65.0)$ & $70(70.0)$ & $67(65.7)$ & $65(64.4)$ \\
\hline Refused to answer & & & & & & & & & & & & \\
\hline $\begin{array}{l}\text { Q32: If one would find it too } \\
\text { costly to obey this law? }\end{array}$ & $46(46.0)$ & $43(41.7)$ & $39(38.2)$ & $52(52.0)^{*}$ & $44(43.6)$ & $44(44.4)$ & $44(43.6)$ & $44(44.4)$ & $33(33.0)$ & $44(44.0)$ & $41(40.2)$ & $52(51.5)$ \\
\hline $\begin{array}{l}\text { Q33: If one knows that this } \\
\text { law is not enforced? }\end{array}$ & $57(57.0)$ & $58(56.3)$ & $65(63.7)$ & $57(57.0)$ & $59(58.4)$ & $60(60.6)$ & $59(58.4)$ & $60(60.6)$ & $55(55.0)$ & $63(63.0)$ & $62(60.8)$ & $69(68.3)$ \\
\hline $\begin{array}{l}\text { Q34: If one knows that } \\
\text { most of the people he or } \\
\text { she knows best do not } \\
\text { follow this law? }\end{array}$ & $36(36.0)$ & $46(44.7)$ & $31(30.4)$ & $41(41.0)^{*}$ & $31(30.7)$ & $39(39.4)$ & $31(30.7)$ & $39(39.4)$ & $24(24.0)$ & $43(43.0)^{*}$ & $36(35.3)$ & $41(40.6)$ \\
\hline $\begin{array}{l}\text { Q35: If one knows that } \\
\text { most people he or she } \\
\text { knows best approve of } \\
\text { breaking this law? }\end{array}$ & $39(39.0)$ & $48(46.6)$ & $31(30.4)$ & $38(38.0)^{*}$ & $34(33.7)$ & $40(40.4)$ & $34(33.7)$ & $40(40.4)$ & $29(29.0)$ & $44(44.0)^{*}$ & $38(37.3)$ & $44(43.6)$ \\
\hline $\begin{array}{l}\text { Q36: If one does not know } \\
\text { this law? }\end{array}$ & $64(64.0)$ & $67(65.0)$ & $65(63.7)$ & $68(68.0)$ & $68(67.3)$ & $73(73.7)$ & $68(67.3)$ & $73(73.7)$ & $63(63.0)$ & $76(76.0)^{*}$ & $78(76.5)$ & 79 (78.2) \\
\hline $\begin{array}{l}\text { Q37: If one thinks that this } \\
\text { law was made without } \\
\text { representing the interests } \\
\text { of people like him or her? }\end{array}$ & $59(59.0)$ & $56(54.4)$ & $56(54.9)$ & $64(64.0)$ & $48(47.5)$ & $60(60.6)$ & $48(47.5)$ & $60(60.6)$ & $46(46.0)$ & $54(54.0)$ & $54(52.9)$ & $57(56.4)$ \\
\hline $\begin{array}{l}\text { Q38: If one knows that this } \\
\text { law is enforced unfairly? }\end{array}$ & $66(66.0)$ & 71 (68.9) & $66(64.7)$ & $65(65.0)$ & $67(66.3)$ & 70 (70.7) & 67 (66.3) & 70 (70.7) & $62(62.0)$ & 72 (72.0) & 76 (74.5) & 78 (77.2) \\
\hline
\end{tabular}

Table 10: Knowledge of FGM/C practise

\begin{tabular}{|c|c|c|c|c|c|c|c|c|c|c|c|c|}
\hline & \multicolumn{2}{|l|}{ Faramana } & \multicolumn{2}{|l|}{ Koury } & \multicolumn{2}{|l|}{ Koloko } & \multicolumn{2}{|l|}{ Finkolo } & \multicolumn{2}{|l|}{ Tansila } & \multicolumn{2}{|l|}{ Boura } \\
\hline & $\begin{array}{l}\text { Male } \\
(\mathrm{N}=100)\end{array}$ & $\begin{array}{l}\text { Female } \\
(\mathrm{N}=103)\end{array}$ & $\begin{array}{l}\text { Male } \\
(\mathrm{N}=102)\end{array}$ & $\begin{array}{l}\text { Female } \\
(\mathrm{N}=100)\end{array}$ & $\begin{array}{l}\text { Male } \\
(\mathrm{N}=101)\end{array}$ & $\begin{array}{l}\text { Female } \\
(\mathrm{N}=99)\end{array}$ & $\begin{array}{l}\text { Male } \\
(\mathrm{N}=100)\end{array}$ & $\begin{array}{l}\text { Female } \\
(101)\end{array}$ & $\begin{array}{l}\text { Male } \\
(\mathrm{N}=100)\end{array}$ & $\begin{array}{l}\text { Female } \\
(\mathrm{N}=100)\end{array}$ & $\begin{array}{l}\text { Male } \\
(\mathrm{N}=102)\end{array}$ & $\begin{array}{l}\text { Female } \\
(\mathrm{N}=101)\end{array}$ \\
\hline $\begin{array}{l}\text { Q73:Are you familiar with } \\
\text { Female genital } \\
\text { mutilation/cutting? }\end{array}$ & $71(71.0)$ & $52(50.5)^{*}$ & $90(88.2)$ & $62(62.0)^{*}$ & $80(79.2)$ & $74(74.7)$ & $87(87.0)$ & $75(74.3)^{*}$ & $82(82.0)$ & $73(73.0)$ & $91(89.2)$ & $75(74.3)^{*}$ \\
\hline $\begin{array}{l}\text { Q76. Do you think that } \\
\text { people in your community } \\
\text { practise female genital } \\
\text { mutliation/cutting? }\end{array}$ & $51(51.0)$ & $48(46.6)$ & $68(66.7)$ & $51(51.0)^{*}$ & $63(62.4)$ & $52(52.5)$ & $80(80.0)$ & $71(70.3)$ & $59(59.0)$ & $49(49.0)$ & $82(80.4)$ & $59(58.4)^{*}$ \\
\hline Q77. How many girls girls & ar commi & do you th & ave bee & & & & & & & & & \\
\hline All the girls & $12(12.0)$ & $9(8.7)$ & $18(17.6)$ & $17(17.0)$ & $8(7.9)$ & $8(8.1)$ & $15(15.0)$ & $20(19.8)$ & $4(4.0)$ & $6(6.0)$ & $6(5.9)$ & $4(4.0)$ \\
\hline Most girls & $17(17.0)$ & $12(11.7)$ & $19(18.6)$ & $16(16.0)$ & $15(14.9)$ & $17(17.2)$ & $21(21.0)$ & $20(19.8)$ & $18(18.0)$ & $19(19.0)$ & $16(15.7)$ & $18(17.8)$ \\
\hline Some girls & $10(10.0)$ & $17(16.5)$ & $17(16.7)$ & $10(10.0)$ & $17(16.8)$ & $17(17.2)$ & $21(21.0)$ & $12(11.9)$ & $16(16.0)$ & $13(13.0)$ & $21(20.6)$ & $20(19.8)$ \\
\hline A few girls & $22(22.0)$ & $13(12.6)$ & $18(17.6)$ & $10(10.0)$ & $29(28.7)$ & $21(21.2)$ & $24(24.0)$ & $25(24.8)$ & $32(32.0)$ & $23(23.0)$ & $45(44.1)$ & $19(18.8)^{*}$ \\
\hline
\end{tabular}




\begin{tabular}{|c|c|c|c|c|c|c|c|c|c|c|c|c|}
\hline & \multicolumn{2}{|c|}{ Faramana } & \multicolumn{2}{|l|}{ Koury } & \multicolumn{2}{|l|}{ Koloko } & \multicolumn{2}{|l|}{ Finkolo } & \multicolumn{2}{|l|}{ Tansila } & \multicolumn{2}{|l|}{ Boura } \\
\hline & \begin{tabular}{|l|} 
Male \\
$(\mathrm{N}=100)$
\end{tabular} & \begin{tabular}{|l|} 
Female \\
$(\mathrm{N}=103)$
\end{tabular} & \begin{tabular}{|l|} 
Male \\
$(\mathrm{N}=102)$
\end{tabular} & $\begin{array}{l}\text { Female } \\
(\mathrm{N}=100)\end{array}$ & \begin{tabular}{|l|} 
Male \\
$(\mathrm{N}=101)$
\end{tabular} & $\begin{array}{l}\text { Female } \\
(\mathrm{N}=99)\end{array}$ & \begin{tabular}{|l|} 
Male \\
$(\mathrm{N}=100)$
\end{tabular} & $\begin{array}{l}\text { Female } \\
\text { (101) }\end{array}$ & $\begin{array}{l}\text { Male } \\
(\mathrm{N}=100)\end{array}$ & $\begin{array}{l}\text { Female } \\
(\mathrm{N}=100)\end{array}$ & $\begin{array}{l}\text { Male } \\
(\mathrm{N}=102)\end{array}$ & $\begin{array}{l}\text { Female } \\
(\mathrm{N}=101)\end{array}$ \\
\hline No girl & $21(21.0)$ & 32 (31.1) & 17 (16.7) & $25(25.0)$ & $26(25.7)$ & $32(32.3)$ & 15 (15.0) & $21(20.8)$ & $25(25.0)$ & $35(35.0)$ & $12(11.8)$ & $35(34.7)$ \\
\hline Don't know & \begin{tabular}{|c|}
$18(18.0)$ \\
\end{tabular} & 20 (19.4) & \begin{tabular}{|c|}
$13(12.7)$ \\
\end{tabular} & $22(22.0)$ & \begin{tabular}{|l|}
$6(5.9)$ \\
\end{tabular} & $4(4.0)$ & $4(4.0)$ & $3(3.0)$ & $5(5.0)$ & $4(4.0)$ & $2(2.0)$ & $5(5.0)$ \\
\hline
\end{tabular}

Table 11: Continuation/discontinuation of FGM/C

\begin{tabular}{|c|c|c|c|c|c|c|c|c|c|c|c|c|}
\hline & \multicolumn{2}{|l|}{ Faramana } & \multicolumn{2}{|l|}{ Koury } & \multicolumn{2}{|l|}{ Koloko } & \multicolumn{2}{|l|}{ Finkolo } & \multicolumn{2}{|l|}{ Tansila } & \multicolumn{2}{|l|}{ Boura } \\
\hline & $\begin{array}{l}\text { Male } \\
(\mathrm{N}=100)\end{array}$ & $\begin{array}{l}\text { Female } \\
(\mathrm{N}=103)\end{array}$ & \begin{tabular}{|l|} 
Male \\
$(\mathrm{N}=102)$
\end{tabular} & $\begin{array}{l}\text { Female } \\
(\mathrm{N}=100)\end{array}$ & $\begin{array}{l}\text { Male } \\
(\mathrm{N}=101)\end{array}$ & $\begin{array}{l}\text { Female } \\
(\mathrm{N}=99)\end{array}$ & $\begin{array}{l}\text { Male } \\
(\mathrm{N}=100)\end{array}$ & $\begin{array}{l}\text { Female } \\
(101)\end{array}$ & \begin{tabular}{|l|} 
Male \\
$(\mathrm{N}=100)$
\end{tabular} & $\begin{array}{l}\text { Female } \\
(N=100)\end{array}$ & $\begin{array}{l}\text { Male } \\
(\mathrm{N}=102)\end{array}$ & $\begin{array}{l}\text { Female } \\
(\mathrm{N}=101)\end{array}$ \\
\hline \multicolumn{13}{|c|}{ Q84. Why do you think people in your community continue to practise female genital mutilation/cutting? } \\
\hline Because everyone else does it & $14(23.3)$ & $17(28.8)$ & $15(20.3)$ & $24(36.4)$ & $16(23.5)$ & $17(30.4)$ & 19 (23.5) & $20(26.3)$ & $15(24.2)$ & $15(29.4)$ & $17(20.7)$ & $12(20.0)$ \\
\hline Religious obligations & $2(3.3)$ & $2(3.4)$ & $2(2.7)$ & $2(3.0)$ & $0(0.0)$ & $1(1.8)$ & $9(11.1)$ & $7(9.2)$ & $3(4.8)$ & $1(2.0)$ & $2(2.4)$ & $1(1.7)$ \\
\hline Tradition & $4(6.7)$ & $4(6.8)$ & $9(12.2)$ & $8(12.1)$ & $2(2.9)$ & $6(10.7)$ & $12(14.8)$ & $14(18.4)$ & $5(8.1)$ & $5(9.8)$ & $10(12.2)$ & $9(15.0)$ \\
\hline $\begin{array}{l}\text { Because there are few penalties for doing } \\
\text { so }\end{array}$ & $15(25.0)$ & $9(15.3)$ & $7(9.5)$ & $8(12.1)$ & $18(26.5)$ & $6(10.7)$ & 15 (18.5) & $14(18.4)$ & $15(24.2)$ & $12(23.5)$ & $21(25.6)$ & $7(11.7)$ \\
\hline Other & $19(31.7)$ & $14(23.7)$ & $30(40.5)$ & $13(19.7)$ & $34(50.0)$ & $26(46.4)$ & $40(49.4)$ & $32(42.1)$ & $25(40.3)$ & 19 (37.3) & $33(40.2)$ & $33(55.0)$ \\
\hline Don't know & $14(23.3)$ & $15(25.4)$ & $17(23.0)$ & $20(30.3)$ & $4(5.9)$ & $5(8.9)$ & $1(1.2)$ & $3(3.9)$ & $1(1.6)$ & $1(2.0)$ & $4(4.9)$ & $1(1.7)$ \\
\hline Refused to answer & $0(0.0)$ & $0(0.0)$ & $0(0.0)$ & $0(0.0)$ & $0(0.0)$ & $0(0.0)$ & $0(0.0)$ & $0(0.0)$ & $0(0.0)$ & $0(0.0)$ & $0(0.0)$ & $0(0.0)$ \\
\hline \multicolumn{13}{|c|}{ Q87. If everyone in your community were to discontinue [female genital mutilation/cutting], would you want it to continue? } \\
\hline Yes & $13(13.0)$ & $11(10.7)$ & $35(34.3)$ & $18(18.0)$ & $17(16.8)$ & $16(16.2)$ & $23(23.0)$ & $25(24.8)$ & $15(15.0)$ & $12(12.0)$ & $10(9.8)$ & $13(12.9)$ \\
\hline No & $83(83.0)$ & $83(80.6)$ & $62(60.8)$ & $71(71.0)$ & $82(81.2)$ & $82(82.8)$ & $76(76.0)$ & 75 (74.3) & $85(85.0)$ & $87(87.0)$ & $92(90.2)$ & $88(87.1)$ \\
\hline Don't know & $3(3.0)$ & $9(8.7)$ & $5(4.9)$ & $11(11.0)$ & $2(2.0)$ & $1(1.0)$ & $0(0.0)$ & $1(1.0)$ & $0(0.0)$ & $1(1.0)$ & $0(0.0)$ & $0(0.0)$ \\
\hline Refused to answer & $1(1.0)$ & $0(0.0)$ & $0(0.0)$ & $0(0.0)$ & $0(0.0)$ & $0(0.0)$ & $1(1.0)$ & $0(0.0)$ & $0(0.0)$ & $0(0.0)$ & $0(0.0)$ & $0(0.0)$ \\
\hline \multicolumn{13}{|c|}{ Q90. In your opinion, when deciding whether to practise [female genital mutilation/cutting], how much consideration is given to whether or not others are doing it? } \\
\hline A lot of consideration & $20(20.0)$ & $24(23.3)$ & $19(18.6)$ & $19(19.0)$ & $21(20.8)$ & $19(19.2)$ & $29(29.0)$ & $19(18.8)$ & $18(18.0)$ & $19(19.0)$ & $17(16.7)$ & $18(17.8)$ \\
\hline Some consideration & $19(19.0)$ & $17(16.5)$ & $27(26.5)$ & $18(18.0)$ & $31(30.7)$ & $33(33.3)$ & $20(20.0)$ & $21(20.8)$ & $22(22.0)$ & $24(24.0)$ & $22(21.6)$ & $30(29.7)$ \\
\hline Not much consideration & $13(13.0)$ & $18(17.5)$ & $13(12.7)$ & $9(9.0)$ & $14(13.9)$ & $17(17.2)$ & $12(12.0)$ & $18(17.8)$ & $25(25.0)$ & $18(18.0)$ & $24(23.5)$ & $16(15.8)$ \\
\hline No consideration & $31(31.0)$ & $17(16.5)$ & $28(27.5)$ & $27(27.0)$ & $35(34.7)$ & $28(28.3)$ & $36(36.0)$ & $39(38.6)$ & $34(34.0)$ & $39(39.0)$ & $39(38.2)$ & $35(34.7)$ \\
\hline Don't know & $17(17.0)$ & $27(26.2)$ & $15(14.7)$ & $27(27.0)$ & $0(0.0)$ & $2(2.0)$ & $3(3.0)$ & $4(4.0)$ & $1(1.0)$ & $0(0.0)$ & $0(0.0)$ & $2(2.0)$ \\
\hline \multicolumn{13}{|c|}{ Q100. Do you believe that female genital mutilation/cutting should continue, or should it be stopped? } \\
\hline Continued & $12(12.0)$ & $15(14.6)$ & $18(17.6)$ & $20(20.0)$ & $10(9.9)$ & $17(17.2)$ & $25(25.0)$ & $34(33.7)$ & $18(18.0)$ & $16(16.0)$ & $13(12.7)$ & $16(15.8)$ \\
\hline Stopped & $86(86.0)$ & $80(77.7)$ & $81(79.4)$ & $68(68.0)$ & $91(90.1)$ & $82(82.8)$ & 75 (75.0) & 66 (65.3) & $81(81.0)$ & $83(83.0)$ & $89(87.3)$ & $84(83.2)$ \\
\hline Don't know & $2(2.0)$ & $8(7.8)$ & $3(2.9)$ & $11(11.0)$ & $0(0.0)$ & $0(0.0)$ & $0(0.0)$ & $1(1.0)$ & $1(1.0)$ & $0(0.0)$ & $0(0.0)$ & $1(1.0)$ \\
\hline Refused to answer & $0(0.0)$ & $0(0.0)$ & $0(0.0)$ & $1(1.0)$ & $0(0.0)$ & $0(0.0)$ & $0(0.0)$ & $0(0.0)$ & $0(0.0)$ & $1(1.0)$ & $0(0.0)$ & $0(0.0)$ \\
\hline
\end{tabular}


Table 12: Social costs and benefits

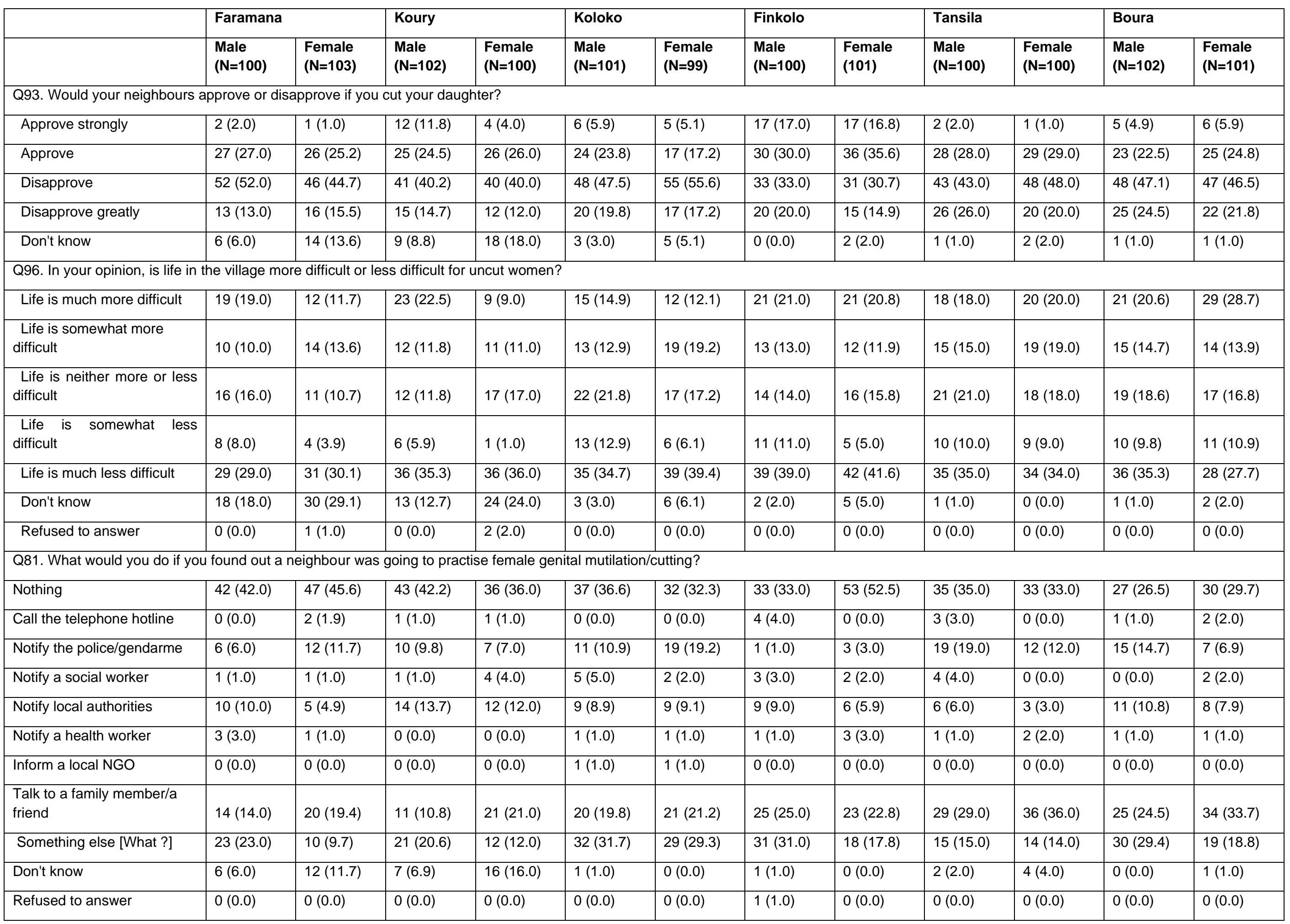

